Thaís de Oliveira Trindade

\title{
Práticas educativas parentais e o comportamento das crianças no contexto da Educação Infantil
}

\section{Tese de Doutorado}

Tese apresentada como requisito parcial para obtenção do grau de Doutor pelo Programa de PósGraduação em Psicologia (Psicologia Clínica) do Departamento de Psicologia da PUC-Rio.

Orientadora: Profa. Luciana Fontes Pessôa

Rio de Janeiro Dezembro de 2020. 
Práticas educativas parentais e o comportamento das crianças no contexto da Educação Infantil

Tese apresentada como requisito parcial para obtenção do grau de Doutor pelo Programa de Pós-Graduação em Psicologia (Psicologia Clínica) da PUC-Rio. Aprovada pela Comissão Examinadora abaixo.

Profa. Luciana Fontes Pessôa Orientadora Departamento de Psicologia - PUC-Rio

Profa. Mariângela da Silva Monteiro Departamento de Psicologia - PUC-Rio

Profa. Karla da Costa Seabra Faculdade de Educação - UERJ

Profa. Leila Sanches de Almeida Instituto de Psicologia - UFRJ

Profa. Vera Maria Ramos de Vasconcellos Faculdade de Educação - UERJ

Rio de Janeiro, 17 de dezembro de 2020 
Todos os direitos reservados. É proibida à reprodução total ou parcial do trabalho sem autorização da universidade, da autora e da orientadora.

\section{Thaís de Oliveira Trindade}

Graduou-se em Pedagogia pela Universidade do Estado do Rio de Janeiro em 2013. Possui Mestrado em Psicologia Social pela Universidade do Estado do Rio de Janeiro. Atualmente pesquisa sobre práticas e crenças de cuidado sob o viés da Psicologia do Desenvolvimento. Participou de congressos na área de Psicologia e Educação.

Ficha Catalográfica

Trindade, Thaís de Oliveira

Práticas educativas parentais e o comportamento das crianças no contexto da educação infantil / Thaís de Oliveira Trindade ; orientadora: Luciana Fontes Pessôa. - 2020.

112 f. : il. color. ; $30 \mathrm{~cm}$

Tese (doutorado)-Pontifícia Universidade Católica do Rio de Janeiro, Departamento de Psicologia, 2020.

Inclui bibliografia

1. Psicologia - Teses. 2. Comportamentos. 3. Práticas parentais. 4. Educação infantil. 5. Família. 6. Professoras. I. Pessôa, Luciana Fontes. II. Pontifícia Universidade Católica do Rio de Janeiro. Departamento de Psicologia. III. Título. 
A tarefa do professor é preparar motivações para atividades culturais, num ambiente previamente organizado, e depois se abster de interferir.

Maria Montessori 


\section{Agradecimentos}

Primeiro gostaria de agradecer a Deus e a todos os guias espirituais que me acompanharam e auxiliaram nessa trajetória, principalmente à Dona Maria. Gostaria de agradecer também pelo apoio da minha família, da minha mãe Simone e avó Nelma que sempre estiveram ao meu lado me apoiando e incentivando. Sem elas não teria conquistado metade do que conquistei até hoje, são minhas bases de amor e carinho que nunca deixaram me faltar nada, não tenho palavras para agradecer, as amo muito. À minha bisavó Eva que segue junto a mim em todos os processos. Ao meu pai, que mesmo em espírito sei que cuida de mim em todos os momentos.

À minha madrinha e Mãe de Santo Ana Cristina, que é como uma mãe em minha vida e sempre está comigo em todos os momentos, e sabe que é uma peça fundamental em tudo na minha vida. Minha tia e madrinha Janaina, meu dindo Leonardo e Fábio que sempre demonstram seu carinho e afeto por minhas conquistas, sei que sempre posso contar com todos eles. Ao meu tio Nelson Carneiro que sempre se coloca a disposição para me ajudar e apoiar em tudo que preciso, muito obrigada também.

Gostaria de agradecer a minha orientadora Luciana por todo suporte, apoio e parceria. Como já disse, ela é realmente orientadora, está sempre nos apoiando em todos os processos, ajuda, dá retornos e é possível sentir a leveza e carinho na sua orientação.

Agradeço também a Vera Vasconcellos, minha eterna orientadora e mentora de vida profissional, queme inspira a seguir na rede pública de Educação Infantil e nas pesquisas acadêmicas. Agradeço a professora Leila Almeida que também me auxiliou nesse processo com suas sugestões e conhecimentos na área.

Agradeço também a professora Karla Seabra por ter aceitado estar nessa banca e por ser uma profissional que admiro tanto.

Sou muito grata por ter tido o auxílio e orientação no mestrado da professora Maria Lúcia Seidl-de-Moura, e sei que sempre poderei contar com ela em minha trajetória acadêmica pela psicologia e educação.

Gostaria de agradecer a todos os membros no nosso grupo de pesquisa Desenvolvimento, Biologia e Cultura, mas preciso citar alguns que foram fundamentais nessa caminha. Isabela Sena, muito obrigada pelo carinho e paciência com minhas dúvidas e inquietações. À Jessica Rosa, agradeço por ter sido aquela parceira 
de aulas, almoços, risadas e diversão nos congressos. Ao Alexandre Sena, agradeço por ser esse ser único e especial, quesempre contagia com alegria a todos que estão ao seu lado.

Preciso agradecer a toda equipe da secretaria da pós graduação, principalmente, Marcelina e Verinha que sempre me recebiam com um sorriso e atenção. Além de sempre ajudarem no que eu estava precisando com muita boa vontade.

À PUC-Rio, pela bolsa de isenção de mensalidades durante o doutorado, sem os quais este trabalho não poderia ter sido realizado.

O que seria de mim sem meus amigos nesses quatro anos de Doutorado, que aguentaram choros, risadas, estresses, ligações, e-mails e centenas de perguntas sobre o que achavam do meu trabalho. Sou extremamente grata a todos eles. Principalmente a Ulhiana, que é a minha fã número 1, Adriana Baca, que muitas vezes acreditava mais no meu potencial do que eu mesma. E aos meus amigos André e Guilherme que se disponibilizaram a realizar as leituras finais da Tese com atenção e carinho. Também a Pedro Vargas, que sempre me ajudava com a formatação e a organização dos gráficos com bom humor e paciência. Agradeço a Mauricio Baca, que mesmo sem ser da área, sempre tinha boa vontade em me ajudar com as ideias e propostas. Ao Affonso Carvalho, que mesmo enrolado, preocupa-se em me dar feedbacks e sugestões, mesmo ás vezes me confundindo, mas faz pensar fora da caixa e a Raphael Soares, que por mais ocupado que estivesse, conseguia sempre dar um suporte e sugestões válidas.

Não deixo de agardecer à família GEUDADE, esse grupo que tanto amo. e que é fundamental na minha vida. Obrigada pelas risadas, conversas, conselhos e trocas. Estão todos no meu coração. Obrigada Andressa Escobar por sempre me ouvir por horas no telefone e sempre fazer com eu relaxe, Luciana Stavale que me dá conselhos de irmã mais velha e também faz eu rir de mim mesma em vários momentos. Paulinha, minha amiga mais doidinha mas que eu amo muito do jeitinho que ela é, agradeço cada papo, cada empurrão e ajuda. Obrigada Dea, Rita e Glória, pelas palavras de sabedoria e amor para seguir a caminhada. Obrigada Renato Dantas, Gabi, Dani, Renato e Ana Lucia por sempre me apoiarem, me darem palavras de incentivo e amizade.

Agradeço a minha prima Nayara que sempre me ajuda de diversas formas e me faz pensar sobre tudo que faço. Carlinha, Paolla, Marianinha e Thai por sempre 
me apoiarem em todas as etapas e processos profissionais. Fernanda, Cibele e $\mathrm{Ru}$ tinha Trevisan, que me equilibram na farra e meditação da vida. Camila Mourão, que mesmo de longe sei que torce por mim em todos os momentos. Não podendo deixar de agradecer àquela amiga antiga da época de escola que está sempre comigo: Caroline, a quem valorizo a presença em tudo na minha vida, cuja amizade e parceria são essenciais para mim.

Não poderia deixar de agradecer as pessoas que estavam ao meu lado em sala de aula ou nas escolas que passei durante esse período de quatro anos. Primeiramente quero agradecer a todos do Espaço Cria que me acolheram, ajustaram-se aos horários das minhas aulas do Doutorado e me deixavam tranquila para cursar o que era necessário durante o doutorado. Agradeço principalmente à Mariana Carvalho e à Livia Diniz, que acreditaram no meu trabalho mesmo em meio a um Doutorado. Obrigada Julia Sorella, Sabrina e Taõa por me darem diversos suportes, desde o emocional até o profissional. Sem elas não teria sido possível sair correndo mais cedo, saber o que ocorreu nas partilhas, sentir que estava tudo bem e tudo ia dar certo.

Ana Leite, obrigada por ser essa pessoa inspiradora e admirável no seu trabalho. Sigo com elaem meu coração sempre. Agradeço a Fernanda Barreto por ser essa pessoa de luz, que me acolheu tantas vezes, sempre aberta a ouvir com o coração e a falar também. Ela foi fundamental nesse processo e a sua playlist também.

Gostaria de agradecer a algumas pessoas que inpiram muito como seres humanos, amigos e educadores na vida; obrigada Catau por sempre ter uma fala coerente e respeitosa com todos e me ensinar tanto; Tabita, por ser essa mulher maravilhosa e cozinheira espetacular, sempre me fazendo rir; Mari Roncarati, por me mostrar que é possível ser acadêmica na Educação Infantil; Diana Aguiar, por me inspirar a ser melhor sempre e a me desafiar no que é possível, Rosa, Luiz e Valentina, que sempre me apoiaram e ouviram nos momentos de dificuldades do processo; Paula Soares, por me ensinar tanto e me fazer olhar cada vez mais para dentro de mim para encontrar as respostas; e Karina Gaia, que segue me inspirando como educadora na vida.

Acredito que muitos quando estão em seus processos criativos e de escrita têm um lugar de aconchegoque, para mim, foi o Folie aux Deux, um café bistrô no Cosme Velho onde eu me deliciava com o cardápio, me inspirava com Marina e Ligia e escrevia capítulos para essa Tese. Obrigada a toda equipe folie. 
Quero agradecer a uma pessoa que chegou de repente e ficou, Debora Nobrega, obrigada por ser essa pessoa e profissional inspiradora e competente. Sou muito grata por ter cruzado com você nessa vida. Muito obrigada também a família Nasser, que me conquistou e que me auxiliou nesse processo final: Giu, Rafael, Nina e Theo. Não posso deixar de lembrar das minhas três amigas que estavam ao meu lado em pleno Outback no shopping tijuca quando vi o resultado que havia sido aprovada para o doutorado. Obrigada July, Dani e Flavinha por estarem em muitos momentos especiais em minha vida e nesse principalmente.

Para finalizar, não posso deixar de agradecer a minha equipe de trabalho na Creche Municipal Elza dos Santos. Rosane e Laís, obrigada por acreditarem no meu trabalho, por sempre me ajudarem nos momentos da pesquisa de campo e emtrevistas. Sem vocês não seria possível. À minha querida amiga e companheira de aventuras na rede municipal, Simone Ferreira, que segue no mestrado e ambas nos apoiando em todos os momentos desse processo acadêmico. Às minhas queridas parceiras de berçário Andrea, Clarinha, Val e Márcia, que seguraram muitas coisas para eu conseguir realizar a pesquisa na rede, meninas não seria nada sem vocês, obrigada pela paciência, carinho, atenção e união sempre. Além delas, as minhas colegas de trabalho Ana Lúcia, Andreia, Helô, Simone e Edilane. Agradeço a Cris Paiva, a Carol Salles e Jéssica também pela parceria e suporte nesse momento da pesquisa na rede municipal do Rio de Janeiro. Agradeço a todas as famílias que aceitaram participar da pesquisa. Muito obrigada a todos vocês sempre! 


\section{Resumo}

Trindade, Thaís de Oliveira; Pessôa Luciana Fontes. Práticas Educativas Parentais e o comportamento da criança no contexto da Educação Infantil. Rio de Janeiro, 2021. 112p. Tese de Doutorado - Programa de Pós-Graduação em Psicologia Clínica, Pontifícia Universidade Católica do Rio de Janeiro.

Um dos pressupostos deste trabalho é que o desenvolvimento humano se dá em contextos. Acedita-se que entender o desenvolvimento durante a Educação Infantil seja necessária à compreensão dos diferentes contextos que fazem parte da vida das crianças. Para tal, será utilizado o modelo de Urie Bronfenbrenner sobre o contexto social, em que as crianças se desenvolvem. Utilizou-se o conceito de $\mathrm{Ni}$ cho de Desenvolvimento proposto por Sara Hrarkness e Charles Super que contribui para a compreensão do papel do contexto no desenvolvimento. A presente tese teve como objetivo investigar as relações das práticas educativas parentais e as características familiares com os comportamentos transgressores das crianças de três a cinco anos do município do Rio de Janeiro. Participaram do estudo 50 pais e 6 professoras de 1 creche localizada em uma favela da Zona Sul do Rio de Janeiro e de 1 Espaço de Desenvolvimento Infantil na Zona Norte do Rio de Janeiro. Foram aplicados os instrumentos: Escala de Crenças Sobre Práticas Parentais na primeira infância, o Inventário do Clima Familiar - ICF e a ficha de dados sociodemográfica. Uma entrevista dirigida com as professoras foi realizada para investigar os objetivos propostos. A partir das análises feitas, pode-se perceber que a maioria dos pais e mães demonstra em suas respostas preocupações e cuidados com seus filhos, visto que para a maioria das afirmativas eles responderam nível 5 (sempre). Esse achado pode ser relacionado com as análises das entrevistas das professoras, que demonstram, de forma geral, que as crianças não apresentam comportamentos agressivos ou transgressores. Para a análise de dados foi utilizado o software Iramuteq. O corpus geral das entrevistas foi constituído por 50 textos, que representam as 50 entrevistas realizadas na pesquisa. Emergiram 8.745 ocorrências (preposições, palavras, formas ou vocabulários), sendo 1094 palavras distintas e 171.047 palavras com uma única ocorrência. Além disso, nos dados sociodemográficos encontram-se participantes com formações que variaram do Ensino Fundamental Incompleto (24\%) ao Superior Completo (4\%). Logo, como nos diz Bronfenbrenner (1992), pode-se verificar as possíveis influências na relação da criança com o ambiente onde está inserida. Acredita-se que, se a criança está inserida em um ambiente saudável para 
seu desenvolvimento, ela dificilmente apresentará comportamentos transgressores ou agressivos nesses espaços. A partir das análises das respostas dos pais e das professoras, pode-se dizer que os aspectos relacionados a crenças e práticas parentais estão de acordo com o perfil de comportamento apontado pelas professoras em suas entrevistas. Acredita-se que o presente estudo possa trazer benefícios tanto para a área de educação quanto para a área da psicologia do desenvolvimento e psicologia da educação.

\section{Palavras-chaves}

Comportamentos; práticas parentais; educação infantil; família; professoras. 


\begin{abstract}
:
Trindade, Thaís de OliveiraI; Pessôa Luciana Fontes (Advisor) Parental Educational Practices and the child's behavior in the context of Early Childhood Education. Rio de Janeiro, 2021. 112p. Doctoral Thesis - Graduate Program in Clinical Psychology, Pontifical Catholic University of Rio de Janeiro.
\end{abstract}

One of the assumptions of this work is that human development takes place in contexts. It is believed that understanding the development during Early Childhood Education is necessary to understand the different contexts that are part of children's lives. To this end, the model of Urie Bronfenbrenner on the social context, in which children develop, will be used. The concept of Development Niche proposed by Sara Hrarkness and Charles Super was used, which contributes to the understanding of the role of context in development. This thesis aimed to investigate the relationship between parental educational practices and family characteristics with the transgressive behaviors of children aged three to five years in the city of Rio de Janeiro. Fifty parents and 6 teachers from 1 daycare center located in a favela in the South Zone of Rio de Janeiro and 1 Child Development Area in the North Zone of Rio de Janeiro.The following instruments were applied: Scale of Beliefs on Parenting Practices in early childhood, the Family Climate Inventory - ICF and the sociodemographic data sheet. An interview directed with the teachers was carried out to investigate the proposed objectives. From the analyzes made, it can be seen that most fathers and mothers show concerns and care for their children in their responses, since for most statements they answered level 5 (always). This finding can be related to the analysis of the teachers' interviews, which demonstrate, in general, that the children do not show aggressive or transgressive behaviors. Iramuteq software was used for data analysis. The general corpus of the interviews consisted of 50 texts, which represent the 50 interviews conducted in the research. 8,745 occurrences (prepositions, words, forms or vocabularies) emerged, with 1094 distinct words and 171,047 words with a single occurrence. In addition, the socio-demographic data includes participants with backgrounds ranging from Incomplete Elementary School (24\%) to Higher Education (4\%). Therefore, as Bronfenbrenner (1992) tells us, one can verify the possible influences on the child's relationship with the environment where he is inserted. It is believed that, if the child is inserted in a healthy environment for his development, he will hardly present transgressive or aggressive behaviors in these 
spaces. From the analysis of the responses of parents and teachers, it can be said that the aspects related to parenting beliefs and practices are in accordance with the behavior profile pointed out by the teachers in their interviews. It is believed that the present study can bring benefits both to the area of education and to the area of developmental psychology and educational psychology.

\section{Keywords}

Behaviors; parenting practices; child education; family; teachers. 


\section{LISTA DE ILUSTRAÇÕES:}

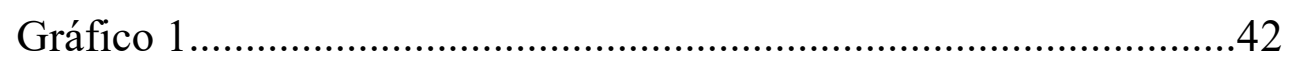

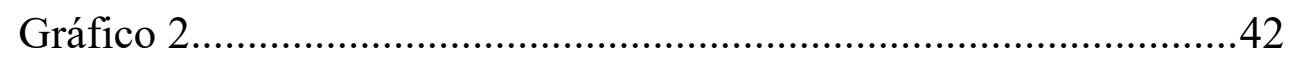

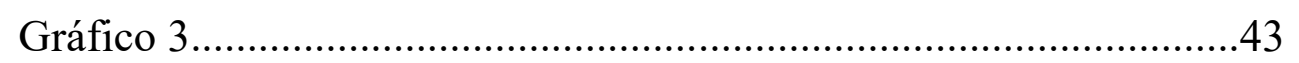

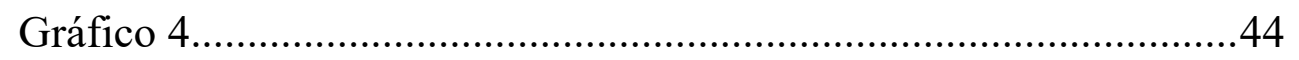

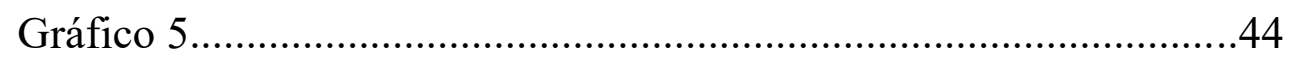

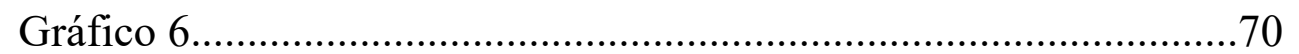

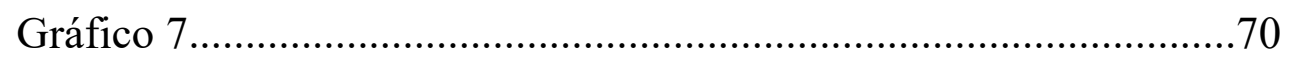

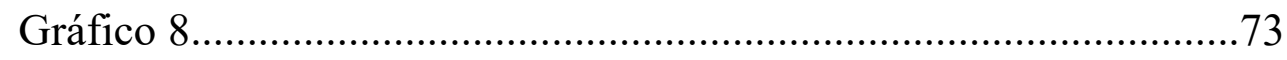

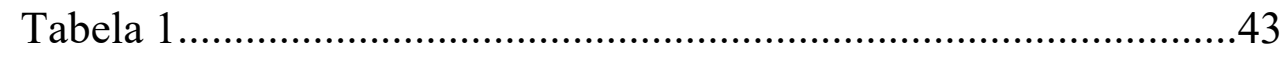

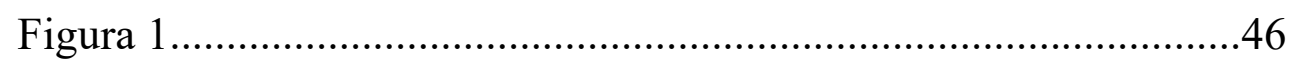

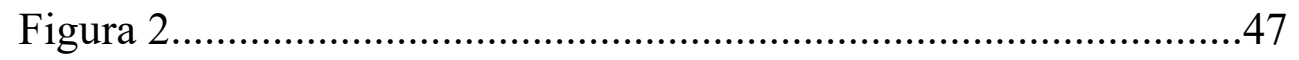

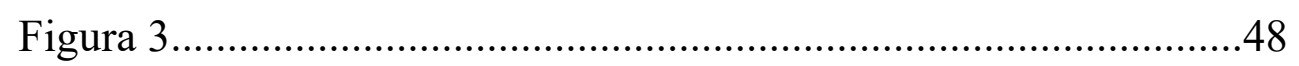

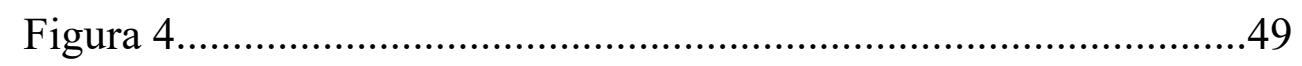

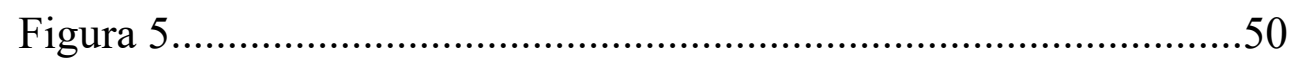

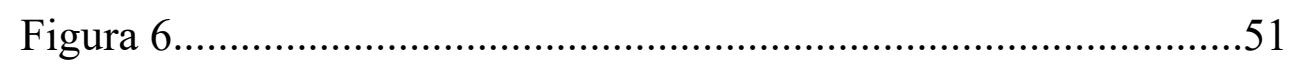

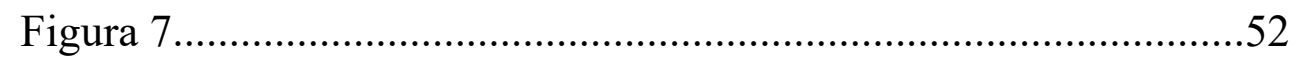

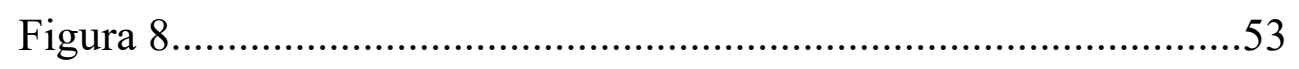

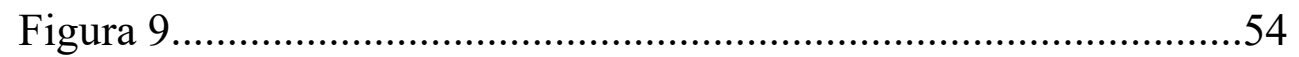

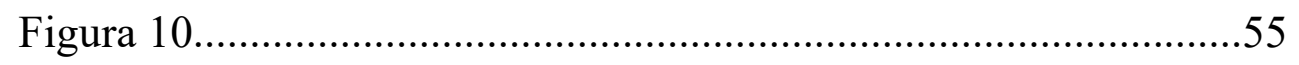

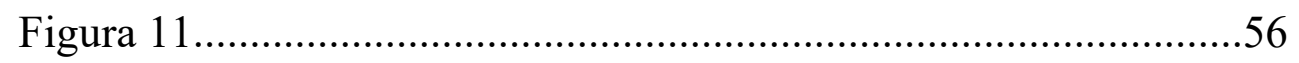

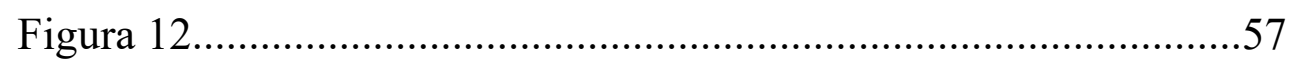

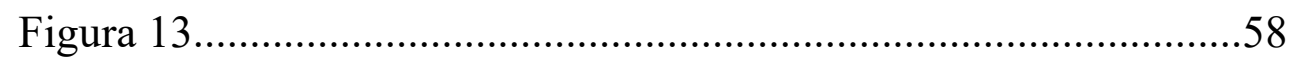

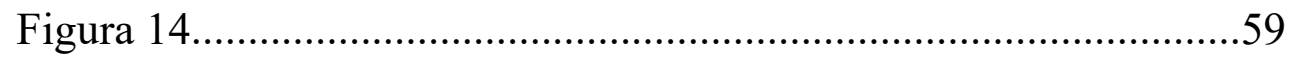

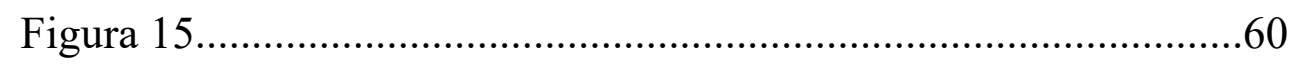

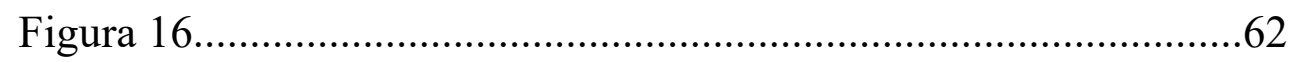

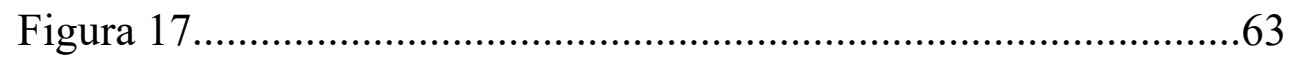

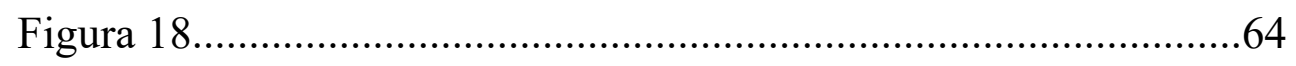

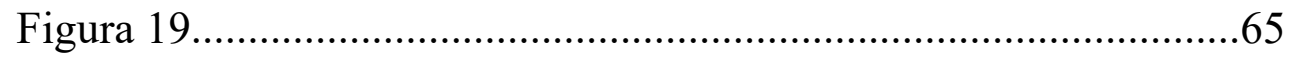




\section{Sumário}

Resumo

Abstract

Introdução

Justificativa

1. A teoria bioecológica do desenvolvimento

1.2 O microssistema família

$1.3 \mathrm{O}$ ambiente da creche

2. Práticas educativas parentais

3. Modos de transgressão

4. Objetivos

5. Método

6. Resultados e discussões 55

7. Considerações finais 85

8. Referências bibliográficas

Anexo I

95

Anexo II 


\section{Introdução}

O estudo das práticas educativas parentais e os seus impactos no comportamento das crianças de 3 a 5 anos na rede pública de ensino do Rio de Janeiro fazse relevante visto que há poucos aprofundamentos referentes a crianças nessa faixa etária e a suas famílias no espaço público de Educação Infantil. Isso acontece principalmente na área de psicologia do desenvolvimento, em que grande parte das pesquisas foram feitas com famílias e crianças da classe média e alta no Brasil.

Durante minha pesquisa de monografia, uma das entrevistadas relatou que o momento pelo qual mais sentiu falta de estar presente na escola de sua filha ocorreu durante a Educação Infantil. Tal fala deu origem aos meus estudos de mestrado. $\mathrm{Na}$ dissertação, encontrei dados que demonstram o quanto carece a comunicação entre pais e professores acerca das crenças e metas dos papéis de cada um, e como podem auxiliar, a partir deles, o desenvolvimento da criança em idade pré-escolar. Com isso, o interesse pelo tema se deveu a minhas experiências em sala de aula na Educação Infantil, além das entrevistas realizadas tanto no mestrado quanto na monografia.

As pesquisas com famílias e professores, pensando na relação de ambos, foi algo que despertou meu interesse desde a graduação em pedagogia. O processo de escuta das famílias e dos professores é importante para pensar a prática e o que se espera para essa criança. Percebo, cada vez mais, o quanto essa integração e participação tornam-se fundamentais para o desenvolvimento da criança, principalmente durante a Educação Infantil.

Outro fator bastante discutido é a questão do cuidar e o educar estarem articulados. Destaca-se, assim, a importância da troca entre pais e professores sobre suas crenças de cuidado e suas metas para as crianças nessa etapa. Desse modo, podem buscar juntos o melhor caminho para a educação e o desenvolvimento da criança. Quando são convergentes, eles podem ter uma relação de parceria, e quando divergentes de complementariedade, podem desenvolver objetivos comuns para a formação integral das crianças, considerando os aspectos cognitivo, emocional, social, psicomotor, moral e ético.

Durante o mestrado, percebi, também, o quanto os professores valorizam crenças relativas ao desenvolvimento da autonomia e das relações sociais nas crianças de 4 a 5 anos. Em contrapartida,os pais e mães às questões relacionadas à 
aprendizagem da leitura e da escrita. Foi possível identificar, ainda, como as crenças sobre o papel da escola e da família foram pouco debatidas pelos diferentes parceiros em questão (Trindade, 2017).

Os discursos dos participantes foram fundamentais para pensar o tema a ser investigado nesta tese, com o intuito de comparar crenças relatadas e práticas realizadas por esses dois grupos de participantes. Com isso, busca-se investigar o quanto as práticas educativas parentais podem ser evidenciadas no comportamento das crianças no ambiente escolar.

Como aponta Cunha (2000), os pais, qualquer que seja a classe social a qual pertençam, não querem que a escola apenas instrua seus filhos; eles querem que a escola os eduque no sentido mais amplo da palavra, que transmita valores morais, princípios éticos, padrões de comportamento. Há tempos considera-se a escola como espaço de formação da personalidade do futuro adulto. Contudo, não se pode esquecer da criança que existe hoje, em processo de formação. Em consonância ao seu processo de formação, enfatizar a necessidade de integrar a família na escola é fundamental para facilitar a forma como a criança será desenvolvido.

Desta forma, os estudos referentes ao impacto das práticas educativas parentais no comportamento de crianças pré-escolares são relevantes para investigar a relação do papel educacional dos pais e o comportamento das crianças, principalmente no ambiente da Educação Infantil. 


\section{Justificativa}

Abordar as relações entre família e escola é sempre pertinente, principalmente, na Educação Infantil, visto que existem duas instâncias que cuidam e educam as crianças, e, por isso, precisam se relacionar. Percebeu-se, a partir de uma revisão integrativa em Psicologia, que a discussão sobre o impacto das práticas educativas parentais no comportamento das crianças, principalmente, no contexto da pré-escola, ainda é pouco investigado.

Além disso, os estudos da área de psicologia do desenvolvimento com famílias e crianças pré-escolares, são, em sua maioria, referentes às famílias de classe média e classe alta ( Bandeira, T. T. A.; Moura M. L. S.; Vieira M. L. (2009); Bahia, C. C. S.; Magalhães, C. M. C.; Pontes, F.A.R. (2008); Bahia, C. C. S.; Magalhães, C. M. C.; Pontes, F. A. R. (2011); Becker, S. M. S. \& Martins, G. D. (2013). Desta forma, identificar tais práticas educativas parentais de cuidado e as possíveis relações com o comportamento da criança na vida escolar faz-se necessária. 


\section{A teoria bioecológica do desenvolvimento}

Um dos pressupostos deste trabalho é que o desenvolvimento humano se dá em contextos. Para entender o desenvolvimento durante a Educação Infantil é necessário a compreensão dos diferentes contextos que fazem parte da vida das crianças. Para tal, será utilizado o modelo de Urie Bronfenbrenner sobre o contexto social, em que as crianças se desenvolvem.

De acordo com Bahia e Pontes (2008), Bronfenbrenner foi um dos estudiosos a investigar a inseparabilidade entre o organismo e o meio. Seus estudos sobre desenvolvimento humano podem situar-se em duas fases:

A primeira pressupõe uma forte influência do papel do ambiente e menos atenção aos processos individuais, enquanto que na segunda fase, Bronfenbrenner (1999) considera que as diferentes formas de interação das pessoas não são apenas função do ambiente. Elas são resultantes de processos, ou seja, das relações entre o ambiente e as características da pessoa. A partir dessa perspectiva, a Teoria de Bronfenbrenner passou a se chamar modelo bioecológico.

O modelo propõe que o desenvolvimento humano seja estudado a partir da interação de quatro núcleos interrelacionados: Processo-Pessoa-Contexto-Tempo. O Processo é o fator fundamental no modelo, com destaque para os proximais, isto é, as interações do organismo e ambiente. Ele engloba as experiências vividas, as interpretações e os significados internalizados pelas pessoas, e entre elas com o ambiente.

De acordo com Bronfenbrenner (1999), os processos proximais são definidos a partir de três aspectos: a necessidade do engajamento em uma atividade, a interação em uma base relativamente regular, a complexidade das atividades. Daí a necessidade de um período estável de tempo, a reciprocidade entre as relações interpessoais e a necessidade que objetos e símbolos presentes no ambiente imediato estimulem a atenção, a exploração e a imaginação da pessoa em desenvolvimento.

O segundo fator que compõe o modelo bioecológico é a Pessoa, com suas características determinadas biopsicologicamente e aquelas construídas através da interação com o ambiente. É uma entidade dinâmica e em crescimento, que influencia e é influenciada pelo meio onde participa. De acordo com esse modelo, a 
pessoa apresenta características para disfunção ou competência, que têm fundamental influência na direção e no conteúdo dos processos proximais. As características de disfunção são aquelas decorrentes da dificuldade em manter o controle e a integração de comportamentos. Já as de competências são as que se referem à aquisição de conhecimentos, habilidades e capacidades para produzir e dirigir o comportamento. Essas características são produtoras e produto do desenvolvimento, influenciando na forma, na força, no conteúdo e na direção dos processos proximais. São também resultantes da interação conjunta dos elementos que se referem ao processo, à pessoa, ao contexto e ao tempo (Bronfenbrenner, 1999).

O terceiro fator do modelo bioecológico refere-se ao Contexto. Este compreende a interação de quatro níveis ambientais, denominados: microssistema, mesossistema, exossistema e macrossistema. O primeiro é definido como um contexto imediato do indivíduo, em que os processos proximais operam para produzir e sustentar o desenvolvimento; é o local no qual as pessoas podem se relacionar face a face. O Mesossistema consiste no conjunto de microssistemas que uma pessoa frequenta e participa ativamente através das interrelações estabelecidas entre eles. Assim, a interação de uma pessoa em determinado local, como o trabalho, é influenciada e igualmente afeta outros ambientes dos quais participa, como por exemplo, a família. O Exossistema envolve os ambientes em que a pessoa não frequenta de forma ativa ou direta, mas que também desempenha uma influência indireta sobre o seu desenvolvimento. Bronfenbrenner (1986) identifica três exossistemas como fundamentais para o desenvolvimento da pessoa: o trabalho dos pais, a rede de apoio social e a comunidade em que a família está inserida (Narvaz \& Koller, 2004).O Macrossistema é visto como uma estrutura social mais ampla e abrange os sistemas de valores e crenças, ideologias, religiões, formas de governo, culturas e subculturas que influenciam o desenvolvimento das pessoas (Bahia \& Pontes, 2008).

O quarto componente do modelo, o Tempo, também denominado Cronossistema, abrange grandes acontecimentos históricos, o momento evolutivo de cada pessoa em desenvolvimento e as características de mudança e continuidade que ocorrem ao longo do ciclo de vida, afetando o desenvolvimento humano (Bahia, 2008).

Durante seus estudos sobre a Ecologia da família, Bronfenbrenner (1986) nos apresenta os diferentes contextos onde a criança está inserida, por exemplo, a 
Família e a Escola. O autor discute como numerosas pesquisas mostram a influência da família no desempenho e comportamento da criança na escola.

Lisboa e Koller (2004) discutem a representação da família, segundo o modelo Bioecológico do Desenvolvimento Humano de Bronfenbrenner. Nele, o núcleo familiar é o espaço onde a pessoa em desenvolvimento experimenta pela primeira vez as relações pessoais diretas e nas quais assume determinado papel social (filho/a, irmão/ã, neto/a).

$\mathrm{Na}$ sociedade atual, percebe-se como os bebês e as crianças são pessoas em diferentes nichos ao mesmo tempo. Por exemplo, alguns bebês que frequentam as creches desde os quatro meses. Desta forma, desde cedo, a pessoa é capaz de transitar entre diferentes microssistemas, alternando papéis sociais ambientais e/ou ambos.

Bronfenbrenner (1986) também aborda a relação entre creche e pais. Ele aponta que o efeito do emprego dos pais e sua relação com a creche pode ser moderado em função do suporte dado entre esses dois microssistemas presentes na vida da criança. Essas considerações retratam que a educação e o cuidar não podem acontecer apenas na creche/escola ou em casa, mas sim de forma compartilhada.

Com isso, a partir de referências mais atuais, as relações que se estabelecem entre as mães e os educadores podem variar muito, dependendo de vários fatores, dentre eles, a qualidade do atendimento da creche e o nível de participação que esta oferece às famílias. Estes dois pontos, evidentemente, apoiam-se em concepções sobre o papel da creche e da família (Oliveira, Mello, Vitória \& Ferreira, 2009).

Pode-se perceber, desta forma, que trata-se da interação entre dois microssistemas, logo do mesossistema. Bronfenbrenner (1977) compreende as interrelações entre as configurações que contenham a pessoa em desenvolvimento em um determinado momento em sua vida. Assim, para um americano de 12 anos de idade, o mesossistema tipicamente engloba interações entre família, escola e grupo de pares; para algumas crianças, isso também pode incluir igreja, acampamento, ou local de trabalho, embora a última fosse menos comum nos Estados Unidos do que em algumas outras sociedades.

O autor chama a atenção para a importância de investigar efeitos conjuntos e interações entre as definições e, assim, destaca a possibilidade de que eventos em um ambiente podem influenciar o comportamento da criança e desenvolvimento em outro. Assim, a experiência de uma criança na creche, na sala de aula, ou no 
grupo de pares informal pode mudar seu padrão de atividades e interação com pais ou irmãos em casa, ou vice-versa, com as consequentes implicações para a aprendizagem e para o desenvolvimento.

Bronfenbrenner (1986) articula seus estudos com outros autores e traz as perspectivas de diferentes pesquisas. Ele cita diversos tópicos como os de desenvolvimento ecológico da família. Não existe a pretensão, neste trabalho, de aprofundá-los, mas alguns deles são citados, apenas para conhecimento: Educação dos pais, Famílias e a comunidade, Família e a mobilidade geográfica, Televisão e a família.

Bronfenbrenner (1977) comenta estudos que indicam que os pais tendem a exibir mais sentimentos positivos no laboratório do que em casa; já as crianças apresentam sentimentos mais negativos quando não estão próximas de seus pais ou em espaços conhecidos.

Em relação a este aspecto específico, pode-se fazer relação com o momento de adaptação da criança na creche, um espaço novo, diferente, em que os pais, muitas vezes, não estão presentes. Bronfenbrenner (1977) ainda acrescenta que quando se está em algum lugar onde não sente-se um conforto ou são espaços nos quais não se está adaptado, ocorre um impacto biopsicológico, o qual influencia o comportamento e desenvolvimento humano, principalmente no caso de crianças pequenas.

O experimento ecológico é um estudo científico da acomodação mútua e progressiva ao longo da vida. Dentre essas definições imediatas temos os contextos sociais, tanto formais quanto informais, em que as configurações são incorporadas. É nesta perspectiva que o objetivo principal do experimento ecológico não se torna hipótese-teste, mas sim descoberta. Busca a identificação dessas propriedades de sistemas e processos que afetam e são afetados pelo comportamento e desenvolvimento do ser humano.

Com isso, nos estudos de estratégias de socialização do autor, identificamse duas estruturas diferentes: a familiar e a creche. Muitas vezes, essas duas estruturas entram em conflito e a questão é: até que ponto esse conflito está sendo positivo ou negativo para o desenvolvimento da criança? Mostra-se importante o conhecimento de ambos os contextos para que seja possível o entendimento dessas estruturas.

Uma propriedade é trazida pelo autor sobre o microssistema, a da reciprocidade, e ele nos mostra como isso funciona com os bebês e seus cuidadores parentais. 
O autor nos diz que não só $\mathrm{A}$ interfere em $\mathrm{B}$, mas os dois se afetam e, ao passar do tempo, esse relacionamento modifica.

O espaço é outro elemento nessa propriedade que influencia as ações e o desenvolvimento das crianças. Um exemplo é uma criança que vive em um espaço muito barulhento ou com muitas pessoas e que precisa estudar. Outro elemento é com relação aos hábitos da família, que também fazem diferença no desenvolvimento da criança. Exemplo: assistir à televisão enquanto almoçam; a interação entre os membros da família enquanto estão juntos, dentre outros. Desta forma, pode-se pensar até que ponto a escola tem conhecimento desses hábitos ou desse espaço, e mesmo se ela se interessa em conhecê-los.

Quando uma criança entra em uma creche, as atividades da família mudam. Além disso, um divórcio pode alterar o comportamento de uma criança na creche; um novo emprego de um dos progenitores pode afetar a casa, a escola e outros espaços de desenvolvimento. Desta maneira, Bronfenbrenner (1977) apresenta como a relação da família com a escola é direta em muitos casos.

Outro modelo teórico que contribui para a compreensão do papel do contexto no desenvolvimento é o de Nicho de Desenvolvimento, proposto por Harkness e Super (1986). Esses autores investigaram bastante a cultura holandesa e a americana, além de coordenarem os projetos globais International Study of Parents, Children and Schools (ISPCS) e The International Baby Study(IBS), além de serem responsáveis pelos recentes estudos sobre Dutch and U.S. parents. Em ambos os paises, os pesquisadores recrutaram uma amostra de 60 famílias com crianças-alvo divididas em cinco grupos etários equilibrados por ordem de nascimento e sexo: 6 meses, 18 meses, 3 anos, 4,5 anos e 7 a 8 anos.

As famílias foram recrutadas principalmente através de redes comunitárias. Elas eram formadas por pessoas de classe média, com ambos os pais empregados e sem grandes problemas de saúde. A maioria delas eram famílias nucleares com ambos os pais presentes no lar e os pais de cada amostra eram todos nativos daquela cultura.

Essas pesquisas foram feitas para demonstrar, cientificamente, que existem muitas diferenças culturais entre os países ocidentais, pois muitos ainda acreditam que não há diferenças entre os cuidados dos países europeus e os Estados Unidos. A partir desses dados e levantamentos, com auxilio dos métodos psicológicos e etnográficos, há evidências dessa diversidade. 
Harkness e Super (2005) entendem que a questão da variabilidade cultural entre as sociedades ocidentais é particularmente relevante quando consideramos ideias e práticas de parentalidade. O Nicho de Desenvolvimento é um sistema dinâmico formado por três subsistemas, que se articulam entre si e delimitam o percurso do desenvolvimento: o primeiro é o ambiente físico e social onde a criança vive; o segundo está relacionado às práticas de cuidado e educação da criança, que são prescritas socialmente; o último refere-se às crenças e valores dos sujeitos encarregados dos cuidados das crianças, suas concepções de infância, educação e desenvolvimento, chamado também de etnoteorias parentais.

No centro do Nicho de Desenvolvimento, está a criança com suas características de sexo, idade, temperamento e outras disposições psicológicas (Bahia \& Pontes, 2008). Considera-se a moradia da família como o centro da vida humana inicial, e o desenvolvimento da criança tendo uma relação dinâmica com o ambiente físico e social, com as práticas de cuidados infantis culturalmente reguladas e com a psicologia de seus pais.

As etnoteorias parentais são modelos culturais que os pais apresentam sobre as crianças, as famílias e eles próprios. O termo modelo cultural, extraído da antropologia cognitiva, indica um conjunto organizado de ideias que são compartilhadas pelos membros de um grupo cultural. Como outros modelos culturais relacionados ao self, as etnoteorias parentais são muitas vezes implícitas, tomadas de ideias sobre a maneira "natural" ou "correta" de pensar ou agir, e têm fortes propriedades motivacionais para os pais. É característico que a relação entre ideias e objetivos para a ação relacione etnoteorias parentais aos outros dois componentes do nicho de desenvolvimento.

Aos recentes esforços para promover a sobrevivência e o desenvolvimento da criança, em nível internacional, tem-se centrado nova atenção sobre a importância da família. Esta deve atuar como um mediador de ambos os riscos ambientais e intervenções programáticas para proporcionar uma saúde melhor. Por isso, em estudos com famílias de diferentes culturas, Harkness e Super (1994), trazem exemplos ilustrativos de pesquisas, incluindo Malásia, Quênia, Bangladesh, Índia e Estados Unidos. Os mesmos mostram como o meio interfere no desenvolvimento das crianças e também como as famílias apresentam individualidades, embora dentro de uma mesma cultura. Além de trazerem o ambiente do lar, os autores tratam do ambiente escolar que essa criança frequenta ou frequentará e como ele 
afeta a rotina, hábitos e atitudes das famílias, além das consequências no desenvolvimento infantil.

Os estudos sobre o Nicho de Desenvolvimento consideram aspectos antropológicos, psicológicos e biológicos. Os antropológicos abordam questões sobre a cultura e a personalidade de cada pessoa; além disso, leva em consideração como funciona a estrutura familiar na qual a criança está inserida e quais os diferentes ambientes e contextos de desenvolvimento que frequenta (Harkness \& Super, 2005).

No âmbito psicológico, encontra-se o subsistema da psicologia dos cuidadores. Este focaliza os sistemas de crenças daqueles que participam dos cuidados infantis em contextos específicos. Já as perspectivas biológicas contribuem com a elaboração sobre o nicho de desenvolvimento, diretamente a partir dos estudos sobre genética e embriologia (Harkness \& Super, 2005).

Assim, o nicho do desenvolvimento baseia-se nos recentes avanços teóricos em antropologia, psicologia e ecologia biológica. Como uma síntese das ideias de cada uma destas disciplinas, o nicho de desenvolvimento é distinto da criança em desenvolvimento no âmbito doméstico. Combina-se assim uma preocupação cultural com noções básicas sobre a organização sistemática do ambientea uma orientação do desenvolvimento para as necessidades biológicas e as capacidades das crianças, bem como suas experiências ao longo do tempo.

Com relação à família, Harkness e Super (1994) também argumentam que, embora a criança e o ambiente sejam vistos como sistemas interativos, o agregado familiar, como o centro da vida humana, é o mediador focal dessa relação, e é fortemente impactado por mecanismos culturalmente construídos. Esses autores apresentam estudos com famílias italianas e americanas, identificando os diferentes costumes de cuidados.

Nas duas perspectivas de desenvolvimento, tanto de Bronfenbrenner (1999) quanto de Harkness e Super (1986), é possível perceber que na noção de contexto estão envolvidas não só as relações interpessoais, mas também as relações em diferentes sistemas.

Em resumo, faz-se uma relação entre o mesossistema e o nicho de desenvolvimento da seguinte forma: como o mesossistema compreende as interrelações e as configurações que contêm a pessoa em desenvolvimento em um determinado momento do seu ciclo vital, ele engloba as interações da família, escola e grupo de 
pares (Bronfenbrenner, 1977). O nicho de desenvolvimento é um sistema dinâmico formado por três subsistemas, que se articulam entre si e delimitam o percurso do desenvolvimento (Harkness \& Super, 1994).

Entende-se que o mesossistema engloba diferentes nichos de desenvolvimento, como, por exemplo, o espaço da escola e o espaço da casa ambos serão mais focados nesta tese, além dos diferentes conjuntos de práticas dos pais. Assim, podese perceber como esses microssistemas estão interligados aos diferentes nichos de desenvolvimento onde as crianças estão inseridas. Desta forma, entende-se que cada família apresenta práticas educativas diferentes para seus filhos. Com isso, dentro desse microsistema da família, consegue-se encontrar contextos menores e individuais que influenciarão de alguma forma o desenvolvimento infantil. Em função disso, não se pode focar em um único modelo singular de família. 


\section{2 o microssistema família:}

Nos últimos dois séculos, houve uma revolução na sociedade que trouxe mudanças profundas à família. A variabilidade histórica da instituição familiar desafia qualquer conceito geral. A generalização do termo termina por ocultar as demais esferas da vida social, porque se tem como regra, em diversos países e concepções teóricas, que pais e seus filhos dependentes constituem uma família, como nos diz Weber (2008, p.10).

A família, enquanto grupo social, sofreu profundas mudanças ao longo do tempo, em função de fatores econômicos, históricos, sociais e culturais, que, consequentemente repercutiram nas relações de seus membros. A família patriarcal do Brasil Colônia era extensa, composta por membros consanguíneos ou não, que circulavam livremente no seio familiar (pais, filhos, outros parentes, agregados e serviçais). O pai era a figura de incontestável autoridade. À mãe, cabia a educação dos filhos, a administração da rotina doméstica e o comando dos serviçais (Almeida \& Vasconcellos, 2018).

As mudanças que ocorreram na dinâmica e na organização das famílias europeias foram influenciando as famílias brasileiras de classe média. Assim, em meados do século XIX, houve um movimento de valorização da intimidade, levando à emergência da família nuclear brasileira (Almeida \& Vasconcellos, 2018).

As abordagens contemporâneas no estudo de família trazido por Dessen e Costa Junior (2005, p. 119) definem seu objeto de base nas seguintes premissas: “ 1 - a noção de família deve estar baseada na opinião de seus membros, considerando a afetividade e a proximidade com os entes queridos como critérios para composição de família e 2 - diversos são os tipos e as possibilidades de família no contexto atual, não se restringindo a uma única forma”.

Atualmente, existem centenas de composições familiares e uma só área de conhecimento ou uma só epistemologia não é suficiente para abarcar todas as possibilidades de compreensão destas novas famílias. Cada profissional, psicólogo ou pensador, tem a sua teoria (e seus dogmas), e novos modelos familiares requerem novas pesquisas sobre o seu funcionamento, como nos diz Weber (2008, p. 10). Famílias por adoção, famílias monoparentais e famílias formadas por pares homossexuais são exemplos de discussões polêmicas.

A adoção, por exemplo, existe desde os primórdios dos tempos, ainda assim, existem mitos e preconceitos sobre esta forma de filiação que prescinde do laço 
genético. As pesquisas de Weber e et al. (2007) revelam que, ao contrário do que supõe o senso comum, práticas educativas parentais são mais responsivas em famílias por adoção quando comparadas a famílias genéticas.

A família é realmente um sistema de sistemas que se interligam de maneira móvel. Uma família é a interrelação das relações básicas de marido-esposa, mãecriança, pai-criança e criança-criança, sendo que estas relações estão imersas em outras relações sociais e culturais (Weber, 2008, p.11).

Além da integração de diferentes sistemas, a família passa por mudanças sistêmicas e dinâmicas, denominadas por Hetherington (1989) de "transições". Essas transições familiares são cada vez mais comuns nos dias atuais. Nos anos 1960, nos Estados Unidos, quase $90 \%$ das crianças passavam sua infância e adolescência em lares com dois pais biológicos casados; hoje, em torno de $40 \%$ das crianças naquele país e 50\% no Reino Unido vivem nessas condições.

O termo família tem sido reconhecido cada vez mais no plural, principalmente quando trata-se do Brasil. A diversidade social, cultural e econômica característica de nosso extenso território brasileiro explica, em parte, o reconhecimento de diversas configurações familiares (Almeida \& Vasconcellos, 2018).

O censo demográfico realizado pelo Instituto Brasileiro de Geografia e Estatística em 2010 (IBGE, 2012) identificou 15 configurações familiares distintas, distribuídas em cinco classes: família uniparental (homem ou mulher morando sozinho), família nuclear (casal com filhos, casal sem filhos, mulher com filhos, e homem com filhos); família estendida (casal com filhos e outro parente, mulher com filhos e outro parente, casal sem filhos e outro parente, e homem com filhos e outro parente); família composta (casal com filhos com não parentes, mulher com filhos com não parentes, e casal sem filhos com não parentes); e família de casal gay (casal formado por dois homens e casal formado por duas mulheres). São lares onde vive apenas uma pessoa ou diferentes conjuntos de pessoas que, tenham ou não uma relação de parentesco, coabitam na mesma residência, buscando a garantia de alimentação e de bem-estar econômico e social (Almeida \& Vasconcellos, 2018).

Alguns fatores fazem com que ocorram mudanças e ajustamentos na família, como, por exemplo, a espera de um bebê ou a morte de algum membro. Com isso, pode-se pensar na família como um sistema dinâmico, composto por sistemas de relacionamentos entre pares, assim como o modelo bioecológico apresentado 
por Bronfenbrenner (1996) e os nichos de desenvolvimento trazido por Harkness e Super (1994).

Diversos fatores podem influenciar esse sistema familiar, por exemplo, quando há alteração no trabalho da mãe ou pai, divórcio, perda de emprego, pobreza, etc. Com isso, pode-se fazer uma alusão ao exossistema de Bronfenbrenner (1996), que envolve os ambientes nos quais a pessoa não frequenta de forma ativa ou direta, mas que também desempenha uma influência indireta sobre o seu desenvolvimento.

O IBGE (2009) apresenta dados sobre a postergação da nupcialidade, o aumento das famílias monoparentais, a diminuição da disponibilidade de tempo e o excesso de individualismo que geram mudanças nas relações no interior das famílias. Tal fato sinaliza que as novas realidades familiares se impõem de forma significativa e que, com elas, surge a necessidade de mensuração desses novos contextos de modo a fornecer subsídios para as políticas voltadas para a família.

Isso demonstra que a busca por um conceito universal de família exclui mudanças históricas sobre a diversidade e a realidade da experiência familiar em qualquer tempo e local particular. Assim, segundo Zahar (1996), o conceito de família não capta a extensão da diversidade de experiências que muitos vivem. A família é uma elaboração ideológica e social, e qualquer tentativa de defini-la como uma instituição delimitada, com características universais, em qualquer lugar ou tempo, necessariamente irá fracassar.

Como apontam Spodek e Sarasho (1998), o trabalho com os membros da família, principalmente os pais, é importante em qualquer nível de educação da criança, especialmente quando se trata de crianças muito pequenas. Uma das intenções dessa tese é mostrar o ambiente da família de baixa renda ou de classe média e como ela se relaciona com a creche ou pré-escola pública no Rio de Janeiro.

Colocando-se em foco, especificamente, o município do Rio de Janeiro, seu território de $1.200 .179 \mathrm{~km}^{2}$ é habitado por uma população de 6.320 .446 pessoas, sendo 3.360.629 do sexo feminino, o que, em números absolutos, é mais da metade da população (53,17\%). Destas, 1.471 .462 pessoas $(43,8 \%)$ são economicamente ativas. Declarou-se chefe de família um total de 998.811 mulheres $(29,7 \%)$, independentemente de viverem ou não com um cônjuge em um mesmo domicílio (Almeida \& Vasconcellos, 2018). 
A partir desses dados, tem-se uma referência de quais famílias estão presentes no município do Rio de Janeiro e o quanto a mulher está se tornando, cada vez mais, a chefe da família. Desta forma, configura-se um dilema presente, em grande parte relativo às mães, apresentado por Oliveira, Mello, Vitória e Ferreira (2009), no momento de matricular ou não seu filho na creche. Isso acontece porque, tradicionalmente, a mulher é ensinada, desde pequena, a valorizar a maternidade e o cuidado dos filhos como funções essenciais para que ela "se complete como mulher", como apresentado anteriormente.

Com isso, para que essa relação ocorra da melhor forma, faz-se necessário um trabalho bem estruturado entre os professores e os pais de suas crianças, visto que a articulação entre essas duas instituições é fundamental para um trabalho de sucesso tanto da escola, quanto da família junto à criança. Por isso, a cooperação ativa dos pais faz diferença nesse processo e defende-se a importância da integração dos membros da família, com os professores e gestores durante a pré-escola.

As autoras Oliveira, Mello, Vitória e Ferreira (2009) lembram que as relações estabelecidas entre as mães e os educadores podem variar muito, dependendo de vários fatores, dentre eles, a qualidade do atendimento da creche e o nível de participação que esta oferece as famílias. Estes dois pontos, evidentemente, apoiam-se em concepções sobre o papel da creche e da família.

Quando há um bom atendimento, as queixas serão mais frequentes e legítimas. Mas se a creche se posiciona como fechada à participação das famílias, oferecendo poucas oportunidades para que estas coloquem seus desejos e preocupações, as queixas não vão aparecer claramente. Contudo, elas não deixarão de existir nas conversas entre as próprias mães, na vizinhança, ou mesmo em gestos e ações que demonstram insatisfação, desinteresse ou pouca colaboração frente às condutas que a creche toma com seus filhos. Mesmo uma creche que ofereça um bom atendimento às crianças, mas que "feche as portas" às famílias, enfrentará também um clima de tensão neste relacionamento (Oliveira, Mello, Vitória \& Ferreira, 2009).

Uma questão polêmica, abordada por Oliveira (2002), é acerca da insatisfação e da acusação entre a escola e a família, responsabilizando uma à outra ao invés de pensarem em práticas, crenças, objetivos e perspectivas comuns que tenham sobre essa criança e soluções comuns para atingi-las. Ela também defende a ideia de considerar a diversidade dos diferentes arranjos familiares presentes em nossa sociedade atual. Aponta os principais conflitos entre a creche e a pré-escola, com a 
família, a questão dos ensinamentos familiares e os propostos pela instituição escolar, normalmente, de situação cotidiana, linguagem e valores.

As famílias também são definidas como unidades de relações sociais, no sentido em que, nelas, os hábitos e costumes, valores e padrões de comportamentos são transmitidos e questionados. As ações e os discursos sobre famílias e práticas familiares são construídos a partir da história social, carregados de valores relativos às diversas configurações familiares.

A família, em decorrência dos avanços sociais, econômicos e tecnológicos, tem mudado seus papéis, suas obrigações e suas estruturas tradicionais. O envolvimento dos pais não só é importante para um diálogo mais aberto entre eles e os professores, mas também vital para que compreendam os objetivos, crenças, práticas e perspectivas da pré-escola onde estão matriculando seus filhos.

Segundo Blatchford (2009), quando os professores incluem os pais na sua rotina de trabalho, esses começam a interagir mais com as crianças em casa, sentem-se mais confiantes em ajudá-los, acreditam que os professores são melhores, mais competentes no que fazem.

Dessa forma, a criança pequena sente a integração das duas instituições e, consequentemente, sente maior segurança. No entanto, para tal envolvimento ocorrer, requer uma avaliação e uma revisão contínua desse processo, para que não haja quebras e falhas no sistema, mas sim uma flexibilidade crescente para mudanças, de acordo com o que é necessário.

Logo, criar condições favoráveis para o desenvolvimento da criança é um dos objetivos comuns das duas instituições. Tanto uma quanto a outra influenciam e ajudam a determinar o curso da vida das crianças.

Alguns pontos são fundamentais para que essa relação dê certo: um deles é a importância da confiança entre os pais e os profissionais da creche, para que assim possam cuidar e educar com autonomia, respeitar os direitos das crianças, e, ao mesmo tempo, a perspectiva dos pais, deixando claros os limites do contexto coletivo. Para isso, é preciso abrir um espaço para as famílias e os profissionais exporem suas insatisfações e negociar as regras, limites e acordos necessários ao processo de compartilhar a educação e o cuidado infantil.

Essa relação entre a família e os profissionais de Educação Infantil constituise gradativamente, permeada por contradições e afinidades na vida cotidiana e na 
educação das crianças. A complexidade dessa relação dá-se devido a diversas questões de gênero, direitos sociais, desigualdade socioeconômica, diversidade cultural, valores, dentre outros (Maranhã \& Sarti, 2008).

Apesar de historicamente a família ser a instituição responsável pela socialização primária da criança, como nos diz Bahia, Magalhães e Pontes (2008), nos dias atuais é comum a frequência de crianças, ainda com meses, em ambientes como creches. Como consequência, a socialização e a educação dos filhos são divididas principalmente com a escola, e as crianças que frequentam em tempo integral acabam convivendo menos com os membros de sua família.

Quando a família compartilha a educação e socialização da criança com a creche, esta atua apoiando as famílias na criação dos seus filhos e a criança passa a viver com seus pares e adultos em um novo contexto com regras e normas próprias. Neste, as relações são centrais, como nos apresentam as autoras Bahia, Magalhães e Pontes (2008). Assim, a relação entre essas instituições não pode ser uma opção que poderá ou não existir, pois ela é imprescindível.

Desta forma, a compreensão sobre a importância da relação família-escola sustenta-se no modelo bioecológico de Bronfenbrenner (1994), o qual afirma que o desenvolvimento humano é desencadeado a partir da interação entre as características pessoais dos indivíduos e os ambientes nos quais estes vivem. Bahia, Magalhães e Pontes (2008) fazem uma relação do modelo com a questão da escola e do lar bastante claro.

Para este autor, o lar e a instituição de educação infantil, para as crianças, formam seus principais microssistemas, pois são os ambientes onde ela interage frente a frente, mas estes mesmos ambientes são micro e exossistemas para pais e professoras. O lar é o exossistema para as professoras, pois estes não o frequentam, mas ainda assim sentem as influências da educação familiar na criança, e a instituição é o exossistema para os pais, pois estes não a frequentam, mas também sentem a contribuição e a presença das professoras no desenvolvimento de seus filhos (BAHIA, MAGALHÃES \& PONTES, 2008, p.17).

A criança é quem faz a ponte entre a creche e a família. No entanto, suas habilidades, principalmente linguísticas e de sociabilidade, ainda encontram-se em desenvolvimento, não conseguindo assim agir como mediador principal entre as instituições. Com isso, a confluência dos microssistemas, família e instituição de Educação Infantil, fornece informações importantes acerca das contribuições dos 
dois espaços na educação das crianças e também enriquecem as práticas educativas tanto dos familiares quanto das instituições.

Se as instituições se inter-influenciam, os processos desencadeados por meio da relação creche-família delineiam oportunidades desenvolvimentais para todos os envolvidos, e tanto a família quanto a creche aprendem aspectos fundamentais sobre a criança e seu desenvolvimento. Assim, de um lado, a creche terá oportunidades de conhecer as particularidades das crianças, das famílias, os problemas que estas enfrentam para oportunizar o desenvolvimento e aprendizagem dos filhos e a maneira como pensam e percebem a creche. De outro lado, as famílias poderão conhecer as características do processo educativo e a estrutura da instituição (BAHIA, MAGALHÃES \& PONTES, 2008, p.18)

Conclui-se, assim, que compartilhar cuidados e educação implica na produção de espaços de encontros entre famílias e profissionais de educação. Esses sujeitos podem ter perspectivas diferentes sobre desenvolvimento e necessidades infantis, o que demanda constante negociação entre as partes. Isso significa que a escola e os professores podem utilizar diversos mecanismos para criar um ambiente mais respeitoso, que possibilite à família e à própria escola demonstrar a multiplicidade de olhares relacionados às crianças e o sentido da responsabilidade compartilhada.

Para tanto, a instituição de Educação Infantil pode adotar linguagens e posturas que favoreçam a aproximação das famílias, para que elas se sintam aceitas, conheçam e compreendam o trabalho pedagógico realizado e, também, possam contribuir no processo educativo das crianças (Bahia, Magalhães \& Pontes, 2008). 


\subsection{0 ambiente da creche}

As primeiras iniciativas educacionais para a primeira infância são os jardins de infância: 1875, 1894 e 1909, no Rio de Janeiro, e 1896, em São Paulo. Paralelo a este, foi criado um curso de formação para professoras de jardim de infância. Situados nas principais cidades da época, localizavam-se em áreas centrais e atendiam crianças das classes média e alta. Em 1879, a Reforma Leôncio de Carvalho, ao estabelecer o ensino primário obrigatório em todos os municípios do Império, determinou que, em todos os distritos houvesse um jardim de infância, com a função de cuidar da formação da criança antes dos seus sete anos. A determinação não passou de letra morta, segundo Nunes, Corsino e Didonet (2011).

Logo em seguida, surgiu uma iniciativa privada, proveniente da área da saúde, mas com visão assistêncial integral à criança: o Instituto de Proteção e Assistência à Infância do Brasil. Ele foi criado em 1880, no Rio de Janeiro, pelo médico pediatra e higienista Arthur Moncorvo Filho, ardoroso participante na luta por comprometer o governo na organização de serviços públicos para a criança. Ao Instituto foram atribuídos objetivos bastante amplos e diversificados: (a) atender aos menores de 8 anos, (b) elaborar leis que regulassem a vida e a saúde dos recém-nascidos, (c) regular o serviço das amas de leite, (d) velar pelos menores trabalhadores e criminosos, (e) atender as crianças pobres, doentes, defeituosas, maltratadas e moralmente abandonadas, (f) criar maternidades, creches e jardins de infância.

Para contextualizar a Educação Infantil no Brasil, faz-se necessário trazer o que a legislação do Plano Estadual de Educação do Rio de Janeiro diz sobre os níveis e modalidades atendidas da educação.

Segundo a Lei de Diretrizes e Bases da Educação Nacional no 9394/1996 em seu art. 15, a educação escolar compreende: 1- a Educação Básica, formada pela educação infantil, pelo ensino fundamental e pelo ensino médio e 2- a educação superior. Sobre a educação básica, segundo o art.16, em conformidade ainda com a LDB 9394/96, compete ao Estado assegurar o ensino fundamental e oferecer, com prioridade, o ensino médio.

A Educação Básica tem por finalidade desenvolver o educando, assegurarlhe a formação comum indispensável para o exercício da cidadania e fornecer-lhe 
os meios e condições intelectuais para progredir no trabalho e em estudos posteriores. Além disso, possibilita a participação em movimentos sociais e responde as demandas da sociedade.

Com relação à Educação Infantil, que é nosso campo de estudo, a LDB 9394/96 (art. 26) apresenta, nas instituições dos municípios que optarem por integrar o Sistema de Ensino do Estado do Rio de Janeiro, que ela tem por finalidade o desenvolvimento integral da criança até os seis anos de idade, em seus aspectos físico, psicológicos, intelectual e social, complementando a ação da família e da comunidade. Além disso, mostra o público-alvo da educação infantil: crianças de zero a três anos de idade, em creches ou instituições equivalentes, e crianças de quatro a seis anos de idade, em pré-escolas (art. 27).

A partir da definição da educação infantil como primeira etapa da educação básica pela LDB, lei n. 9394/1996 (Brasil, 1996), que assegura atendimento gratuito em creches e pré-escolas às crianças de 0 a 6 anos de idade, tendo por base a Constituição Federal do Brasil de 1988, houve o reconhecimento do direito da criança pequena ao acesso à educação infantil em creches e pré-escolas. Essa lei colocou a criança no lugar de sujeito de direitos, em vez de tratá-la como objeto de tutela, como anteriormente. Em 1988, ficou assegurado que: " O dever do Estado com a educação será efetivado mediante garantia de : [...] atendimento em creche e préescolas às crianças de 0 a 6 anos de idade" (Brasil, Congresso Nacional, 1988, artigo 208, inciso IV). Nesta mesma direção, a LDB, pela primeira vez na história das legislações brasileiras, proclamou a educação infantil como direito das crianças de 0 a 6 anos e dever do Estado. Ou seja, todas as famílias que optarem por partilhar com o Estado a educação e o cuidado de seus filhos e filhas deverão ser contempladas com vagas em creches e pré-escolas públicas.

A lei mais atual que provoca modificações nessa relação da família com a pré-escola é a Lei 12.796 de 4 de abril de 2013. A partir dela, tornou-se obrigatória a educação básica, a partir dos quatro anos de idade, o que muda, de certa forma, a relação da família com a escola. Se anteriormente os pais colocavam as crianças nas pré-escolas, porque desejavam ou por necessidade, agora se torna obrigatória tal educação.

Atualmente, tem-se a Base Nacional Comum Curricular (BNCC) sendo debatida por diversos grupos da área de educação básica. Este documento é de caráter 
normativo que define o conjunto orgânico e progressivo de aprendizagens essenciais que todos os alunos devem desenvolver ao longo das etapas e modalidades da Educação Básica, de modo a que tenham assegurados seus direitos de aprendizagem e desenvolvimento, em conformidade com o que preceitua o Plano Nacional de Educação (PNE). O documento normativo aplica-se exclusivamente à educação escolar, tal como a define o $\S 1^{\circ}$ do Artigo $1^{\circ}$ da Lei de Diretrizes e Bases da Educação Nacional (LDB, Lei n $\left.{ }^{\circ} 9.394 / 1996\right)$, e está orientado pelos princípios éticos, políticos e estéticos que visam à formação humana integral e à construção de uma sociedade justa, democrática e inclusiva, como fundamentado nas Diretrizes Curriculares Nacionais da Educação Básica (BRASIL, 2017).

Desta forma, com esse documento em vigor, há algumas consequências para os espaços de Educação Infantil, visto que, neste documento existem modificações curriculares para a área de Educação Infantil.

Considerando que, na Educação Infantil, as aprendizagens e o desenvolvimento das crianças têm como eixos estruturantes as interações e a brincadeira, assegurando-lhes os direitos de conviver, brincar, participar, explorar, expressar-se e conhecer-se, a organização curricular da Educação Infantil na BNCC está estruturada em cinco campos de experiências, no âmbito dos quais são definidos os objetivos de aprendizagem e desenvolvimento. Os campos de experiências constituem um arranjo curricular que acolhe as situações e as experiências concretas da vida cotidiana das crianças e seus saberes, entrelaçando-os aos conhecimentos que fazem parte do patrimônio cultural (BRASIL, 2017).

A partir desses dados, pode-se pensar como essa articulação de contextos se dará. Cabe ressaltar que, para acompanhar o desenvolvimento infantil, é necessário um olhar apurado e conhecedor sobre o ritmo de cada criança, e de modo que não somente a contemple, mas que considere o ambiente como um todo. Assim, levar em conta os contextos que estão inseridas as crianças de forma a privilegiar o ambiente escolar e o familiar, entendendo que são contextos interligados e intencionalmente mediados por significados, no qual o brincar é o fator que mais favorece o desenvolvimento (Vasconcellos, 1998). Da mesma forma que Bronfenbrenner (1986), ao destacar a importância de pensar a criança em conjunto com as suas experiências vividas e internalizadas, suas características determinadas biopsicologicamente e aquelas construídas através de sua interação com o ambiente no tempo cronológico que ela está vivendo, com os diferentes contextos que permeia. Estes 
se iniciam na família - microssistema - até uma estrutura social mais ampla que abrange valores, crenças, ideologias, religião - macrossistema.

No contexto de desenvolvimento da criança, há de se atentar que os estudos tradicionais de desenvolvimento humano atribuem grande ênfase à maturação biológica. Sobre isso, Palácios e Paniagua (2007) explicam que, ao olhar para o desenvolvimento da criança pequena, devemos atentar inicialmente para o seu corpo e depois para os movimentos. Com isso, corpo e movimento são uma marca da expressividade infantil na primeira infância, período repleto de transformações de aspecto físico e motor. Como os autores evidenciam, esse parece mesmo ser um período em que o desenvolvimento biológico tem preponderância sobre os demais.

Apesar de considerar os aspectos biológicos em seu caráter maturacional, Silva e Oliveira (2016) dizem ser preciso levar em conta também que cada criança tem um ritmo de desenvolvimento. Nem todos alcançam marcos sequenciais ao mesmo tempo e alguns podem mesmo pular algumas etapas (como por exemplo, andar sem ter nunca engatinhado). Lidar com as diferentes trajetórias do desenvolvimento de uma criança pode ser um desafio para pais e professores, pois os contextos em que as crianças vivem, influenciam seu desenvolvimento, bem como sua própria estrutura biopsicossocial, tornando-as atores e autores de seu processo de desenvolvimento.

A Abordagem Ecológica de Bronfenbrenner (1986) também apresenta a importância de olhar o desenvolvimento da criança a partir de várias lentes, e não com uma visão simples e comum a todas. Cada pessoa possui características e passa por experiências de forma singular no meio e na cultura em que está inserida. Por isso, reforça-se a importância de entender o desenvolvimento humano de forma ampla e individualizada, levando em conta os diferentes aspectos que influencia tal processo.

Todos esses aspectos são presentes no ambiente da creche, considerado por Vasconcellos, Seabra, Eisenberg e Moreira (2012) como um espaço e agente de desenvolvimento infantil, em complemento à família. Para esses autores, é a família que participa da primeira produção de sentidos de vida do bebê. A creche e a préescola representam um espaço onde são negociados os sentidos trazidos pela criança e sua família com os dos professores, fazendo com que os valores e crenças de uma parte possam ser negociados e revalidados pelas outras. 
Para ocorrer tal integração da família na pré-escola, entretanto, necessita-se de uma gestão participativa e colaborativa entre pais, mestres, coordenação e direção, sem deixar de considerar as particularidades de cada família e de cada criança. Desta maneira, buscam-se possíveis formas de integrar as famílias na Educação Infantil, para que as crianças tenham uma formação educacional integral.

Com isso, lembra-se a importância da família dentro desse contexto, como ela se relaciona com esse espaço educacional e com esses adultos que educam e cuidam de suas crianças. Tanto a escola quanto família são os núcleos principais de desenvolvimento da primeira infância, por isso, mais uma vez, faz-se importante destacar a importância de articulação entre a família e o ambiente escolar no processo de desenvolvimento infantil. 


\section{2- Práticas educativas parentais}

Os estudos de Friedlmeier, Schäfermeier, Vasconcellos e Trommsdorff (2007), referentes às orientações culturais de pais e professores residentes no Brasil e na Alemanha, trazem três subtópicos: o primeiro - todos os cuidadores de um mesmo grupo cultural compartilham os mesmos valores em geral e esses valores se manifestam na prática diária, além de afetar as crenças individuais dos professores; o segundo - para ter uma descrição mais extensa, pode-se executar testes empíricos sobre esses valores; o terceiro - grande parte dos estudos foca na perspectiva da mãe como cuidadora e assumem isso como um consenso geral dos cuidadores.

No entanto, a convergência entre os valores maternos e os das professoras é uma questão empírica aberta e foi raramente analisada. Em culturas individualistas como a da Alemanha e a dos Estados Unidos, as metas de desenvolvimento orientadas para autonomia, independência, realizações próprias e autoconfiança são preferenciais por boa parte dos cuidadores.

Friedlmeier et al. (2007) argumentam que um dos fatores que pode influenciar a forma de cuidado das crianças no Brasil é a forte diferença socioeconômica e de trabalho das professoras de creches públicas e privadas. Enquanto as primeiras recebem crianças de famílias de baixa renda, as segundas recebem crianças e famílias de renda média a alta. Além disso, as condições de trabalho são diferentes, o que pode vir a afetar a construção de práticas nos dois grupos. Na Alemanha essa variedade não ocorre, pois tanto as creches públicas quanto as privadas apresentam condições similares de trabalho para as professoras.

Bandioli e Mantovani (1998) são coerentes quando relatam que é uma abstração pensar na criança desligada da realidade social na qual se encontra inserida e, portanto, separada das necessidades da própria família. É importante considerar que outros contextos, como a creche, também influenciam no comportamento da criança e não apenas o seu endereço social.

Melchiori, Alves, Souza e Bugliani (2007) discutem a questão da vivência das crianças pequenas em dois contextos da atualidade, o lar e a creche. As crianças podem ser cuidadas por pessoas com bases socioculturais diversas, com experiências parentais prévias variadas, de status profissional e nível educacional muitas vezes divergente. 
Dentro da mesma perspectiva, De Vitta e Emmel (2004) destacam a contradição presente na maneira como é vista a função da creche por professoras da Educação Infantil em uma cidade do interior de São Paulo. Apesar de tentarem incorporar objetivos educacionais, elas se contradizem ao enfatizarem o seu papel assistencialista e a preocupação em compensarem as faltas e/ou dificuldades das mães e das famílias que frequentam a creche. Além disso, Maistro (1997) aponta que muitas professoras ainda têm como ideário a família nuclear burguesa.

Almeida (2013) apresenta, em seus estudos, que as professoras de creches veem a adaptação da criança nesses espaços como algo difícil e que, por isso, elas acabam agindo como se todos os bebês e todas as famílias fossem iguais. Desta forma, acabam ignorando os diferentes hábitos e práticas de cada um cuidar e educar a criança, enquanto que poderiam incluir a família nesse momento de adaptação e aprender com ela as diversas formas de cuidado a que a criança já está acostumada.

Keller (2007) descreve seis sistemas parentais, organizados de acordo com trajetórias distintas. O sistema de cuidados, considerado o mais antigo em termos de filogênese, envolve um conjunto de atividades para atender às necessidades do bebê, como: banho, alimentação, etc. O sistema de contato corporal consiste em favorecer o contato corporal, a partir de posições que favoreçam isso de forma predominante. O sistema de estimulação corporal também é baseado na comunicação através do corpo e envolve qualquer estimulação motora, tátil e/ou equilíbrio do bebê. O sistema de estimulação por objetos tem por objetivo apresentar o mundo dos objetos à criança e o ambiente físico em geral. O sistema face a face é caracterizado, basicamente, pelo contato visual mútuo. O envelope narrativo consiste em toda a mediação simbólica em que o bebê é envolvido, através da fala da mãe (Keller, 2007).

Para Keller (2007), há uma hipótese de duas trajetórias principais no desenvolvimento do self, uma ocidental e outra não-ocidental, que se relacionam a diferentes modos de investimento parental. As variações culturais em termos de cuidados parentais são vastas e há diferenças consideráveis no que diz respeito às oportunidades e ocorrências de interações com os outros, principalmente com membros da família. Desta maneira, o contexto ecológico no qual o desenvolvimento se dá, interfere nos tipos de metas de socialização que são valorizadas e, portanto, nos sistemas de cuidados predominantes. 
Keller et. al (2004) comparam três grupos de diferentes culturas: um de classe média urbana da Grécia, outro de fazendeiros dos Camarões e outro de classe média de Costa Rica. Os autores buscaram observar quais relações apareciam entre o estilo parental de cuidado em bebês de três meses de idade e os aspectos de autorreconhecimento e autorregulação dos mesmos bebês aos 18-20 meses de idade. Verificaram que, no grupo grego, ocorreu uma estratégia de cuidado distal, baseada na estimulação por objeto e na interação face a face, o que mostra uma trajetória mais voltada para a independência. Já no grupo de Camarões, viu-se uma estratégia proximal, calcada no contato corporal e na estimulação corporal que representa uma trajetória mais interdependente. No grupo costa-riquenho, houve a combinação de ambas as estratégias, ou seja, uma trajetória autônomo-relacional.

Sendo assim, no contexto em que a autonomia do sujeito é mais valorizada, o autorreconhecimento desenvolve-se primeiro. Para sociedades que valorizam trajetórias mais independentes, é importante que o sujeito saiba bem quem ele é, o que quer e que busque suas metas com iniciativa. Com isso, faz-se necessário que ele se autorreconheça como alguém único e diferente dos outros. Já a valorização da autorregulação ocorreu no contexto da interdependência, uma vez que neste ambiente a harmonia do grupo é o mais relevante.

Considerando todos os modelos e sistemas apresentados até o momento, ressalta-se a importância do contexto no desenvolvimento da criança e destaca-se a pré-escola e a família como sendo dois nichos de desenvolvimento centrais neste período inicial e, com isso, a relevância da integração entre ambos se faz compreensível e fundamental no processo.

Uma revisão integrativa de literatura na área da psicologia foi realizada para verificar estudos publicados que investigavam práticas educativas parentais e sua relação com o comportamento de crianças pré-escolares. Foram encontrados apenas cinco artigos em três bases de dados: Scielo, Lilacs e Capes.

A primeira base de dados foi a Scielo, com os seguintes descritores: educação infantil or pré-escolas; professores and pais. Com essa primeira tentativa, nenhum artigo foi encontrado. Em uma segunda tentativa, as palavras foram: práticas educativas parentais; educação infantil or pre-escola, mas também não foi encontrado trabalho correspondente. Na terceira tentativa, foram utilizadas as seguintes palavras-chave: práticas educativas parentais and professores and pré-escola, também sem nenhum documento encontrado por essa base de dados. 
A segunda base de dados utilizada foi a dos periódicos CAPES, com os mesmos descritores utilizados na segunda base. Foram encontrados três artigos, porém nenhum deles foi utilizado, pois um tratava de crianças de 8 a 11 anos, outro abordava sexualidade e infância, e o terceiro focava na validação de um questionário sobre respostas socialmente habilidosas.

A terceira base de dados utilizada foi a Lilacs, com os seguintes descritores: educação infantil or pré-escola and práticas educativas parentais. Foram encontradas nessa busca três artigos, mas apenas um foi selecionado. O critério de exclusão foi a faixa etária. O artigo selecionado nesta busca foi o de Bolsoni-Silva e Marturano (2007), que descreve, a partir de relatos, as relações que os pais estabelecem com os filhos pré-escolares, comparando habilidades sociais educativas parentais de pais e mães de crianças com e sem problemas de comportamentos na escola. A pesquisa foi feita em escolas de educação infantil de uma cidade em São Paulo. Nesta pesquisa participaram mães e pais biológicos de 24 crianças com problemas de comportamentos e 24 crianças indicadas como socialmente habilidosas.

Em seguida, alguns descritores foram alterados para: práticas parentais and pré-escola or educação infantil and comportamento escolar. Nesta busca foram encontrados 27 artigos, mas destes foram selecionados quatro, pois a maioria não se coadunava com a faixa etária proposta nessa tese. Os artigos selecionados foram: "1- Relação entre funções parentais e o comportamento de crianças pré-escolares (Zanetti \& Gomes, 2014)”; "2- Interação família-escola diante dos problemas de comportamento da criança: estudos de caso (Silveira \& Wagner, 2012)”; “3- Práticas educativas parentais, problemas de comportamento e competência social de crianças em idade pré-escolar (Marin, Piccinini, Gonçalves \& Tudge, 2012)” e "4Preditores de comportamentos e competência acadêmica de crianças de famílias nucleares, monoparentais e recasadas (Leme \& Marturano, 2014)”.

Zanetti e Gomes (2014) procuraram compreender a relação entre a fragilização das funções parentais e a frequência de comportamentos de agressividade, teimosia e/ou agitação em crianças de dois a quatro anos, num ambiente escolar. Foram feitas entrevistas semi-dirigidas com professores e pais, observação de crianças e interação lúdica entre pais e filhos. Os autores utilizaram uma abordagem qualitativa, por meio de estudo de caso, com comparação entre grupos. Constatou-se que os comportamentos das crianças se relacionavam com dificuldades nas dinâmicas da parentalidade e da conjugalidade. 
Silveira e Wagner (2012) buscaram compreender como a família e a escola partilham a socialização de crianças em idade escolar com problemas de comportamento, investigando a continuidade e/ou descontinuidade das práticas educativas utilizadas pelas mesmas. Foram estudados três casos, junto a entrevistas feitas com pais e professores de crianças de escolas particulares de Porto Alegre, a partir do delineamento de estudos de caso. A discussão dos dados destaca a falta de modelos integrativos família-escola e a necessidade de maior conhecimento e flexibilidade de fronteiras entre os sistemas familiar e escolar.

Piccinini, Gonçalves e Tudge (2012) investigaram a relação das práticas educativas parentais, problemas de comportamento e a competência social de crianças pré-escolares. Participaram 48 mães e 33 pais, cujos primogênitos tinham seis anos de idade, que responderam a uma entrevista sobre práticas educativas e sobre Sistema de Avaliação das Competências Sociais, o qual também avalia problemas de comportamento. Correlações de Spearman revelaram associações positivas entre práticas coercitivas maternas e problemas de comportamento infantil, especialmente os de externalização.

Leme e Marturano (2014) identificaram os preditores de habilidades sociais, problemas de comportamento e competência acadêmica de crianças, em um momento sensível do desenvolvimento, isto é, na transição para o primeiro ano do ensino fundamental. Participaram 160 mães de diferentes configurações familiares, cujos filhos estavam matriculados no primeiro ano do ensino fundamental, e 22 professoras das crianças como informantes. Os instrumentos utilizados foram: Inventário de Práticas Parentais; Sistema de Avaliação de Habilidades Sociais; Inventário de Recursos do Ambiente Familiar. De forma geral, segundo os relatos das mães, as crianças de famílias nucleares apresentaram mais habilidades sociais e menos problemas de comportamento que as crianças de famílias recasadas. Para as professoras, não houve diferenças nas habilidades sociais e na competência acadêmica das crianças de famílias nucleares e recasadas, mas, de acordo com sua avaliação, as crianças de famílias recasadas apresentaram mais comportamentos externalizantes quando comparadas a outras de famílias nucleares.

Com isso, percebeu-se o quanto há uma carência de estudos referentes a etapa do desenvolvimento da educação infantil que se refere a pré-escola, e as relações das práticas educativas parentais com o comportamento dessas crianças no ambiente escolar. Muitos estudos encontrados estão relacionados aos adolescentes 
e as práticas educativas parentais, ainda assim com pouco enfoque no aspecto escolar. Por isso, faz-se relevante a investigação dos impactos das práticas educativas parentais nos comportamentos das crianças pré-escolares. 


\section{3- Modos de transgressão}

A ideia de transgressão é compreendida como ataque e investidas a valores e regras sociais, aos modelos de criação e educação, às instituições ou grupos que as representam. A transgressão pode ser percebida como uma agressão às normas instituídas, uma agressão à lei vigente e aos pais (Domingues et al., 2013).

Acredita-se que a presença da transgressão durante o período da Educação Infantil é esperada, visto que as crianças dessa faixa etária estão em uma etapa do desenvolvimento social em que é comum a ocorrência de tais comportamentos para seu aprendizado na relação com o outro.

As relações que acontecem entre os grupos de pares durante a infância formam um importante contexto de socialização. Este faz com que a criança busque ocupar seu espaço entre indivíduos com características similares (Manfroi, Faraco, \& Vieira, 2010). Isto é, quando a criança se encontra nos espaços da creche ou da pré-escola, muitas vezes, a sua relação inicial se dá junto a crianças que apresentam características similares as dela ou àquelas que apresentam interesses em comum. Com isso, a Educação Infantil tem papel importante na socialização das crianças com seus pares, visto que, neste contexto, elas realizam parte expressiva de suas intenções sociais com outras crianças. Isso torna o ambiente escolar um espaço propício para a promoção do desenvolvimento infantil, assim como para identificação e/ou desenrolar de problemas de comportamento na infância (Souza, Vieira \& Crepaldi, 2015). Dentre esses comportamentos, a agressividade ou modos transgressores são um dos principais motivadores de demandas recorrentes de auxílio por parte de famílias, professores e demais profissionais aos serviços de psicologia (Souza, Vieira \& Crepaldi, 2015).

A incidência de comportamentos agressivos ou transgressores na infância acontece mediante a influência de múltiplas variáveis biológicas e psicossociais (Borsa \& Bandeira, 2014). Por exemplo, há estudos que sinalizam que a exposição aos conteúdos violentos da mídia pode proporcionar um aumento de comportamentos agressivos de crianças (Bushman \& Huesmann, 2006, 2010; Carnagey et al., 2007; Gomide, 2000; Lanz et al., 2010; Perez-Olmos et al., 2005).

Outros estudos (Lansford et al., 2011; Patterson \& Yoerger, 2002) apontam que o baixo suporte emocional familiar, além do baixo nível socioeconômico, assim 
como as práticas educativas parentais com foco na disciplina física punitiva contribuem para a manifestação de comportamentos agressivos na infância. Ainda que não se coloque em xeque os comportamentos agressivos ou transgressores como produtos do complexo processo interacional entre variáveis individuais e contextuais, as quais perpassam o desenvolvimento da criança, não se pode concluir qual aspecto possui maior impacto para o surgimento e a manutenção desses comportamentos (Borsa \& Bandeira, 2014).

Por outro lado, tais comportamentos são constituintes do indivíduo e podem ser necessários para a adaptação humana, pois, por meio deles as crianças experimentam e externalizam sentimentos de raiva, rejeição de pares e frustração (Tremblay, 2000). A persistência e a intensidade dos comportamentos agressivos podem estar associadas a possíveis dificuldades nos relacionamentos sociais e afetivos em geral (Baron et al., 2007), fracasso acadêmico, comportamento delinquente e abuso de substâncias, entre outros (Landim \& Borsa, 2017).

A Teoria Bioecologia do Desenvolvimento Humano, de U. Bronfenbrenner, propõe compreender esse fenômeno - comportamentos agressivos - também como uma forma interacional, isto é, como manifestação à influência que exercem os contextos vivenciados pelos seres humanos em seu desenvolvimento. Ou seja, analisar os fatores de risco e de proteção presentes no modelo de análise da Teoria Bioecologia do Desenvolvimento Humano, denominado Processo-Pessoa-ContextoTempo.

O processo proximal, como já apresentado anteriormente, está relacionado a como a pessoa em desenvolvimento ressignifica suas experiências e interpreta o ambiente em que vive. Além da relação com as outras pessoas, inclui a interação com outros contextos, objetos e símbolos. Como sinalizam Bronfenbrenner e Morris (1998), os processos proximais são os principais motores do desenvolvimento (p.996). Isto é, como a criança vivencia suas atividades cotidianas ou inesperadas, como interage com sua família, com conhecidos e vizinhos. Segundo os autores, para que o desenvolvimento ocorra de forma esperada, os objetos presentes nesse contexto devem estimular a exploração, a imaginação, a atenção e a manipulação da pessoa em desenvolvimento. Além disso, essas interações devem ser progressivas, estáveis e recíprocas (De Antoni \& Koller, 2017).

A segunda instância de análise a ser abordada é a pessoa, que, para Bronfenbrenner (1996), deve ser compreendida em sua dimensão biopsicossocial. Ela é 
analisada por meio de suas características determinadas biopsicologicamente (experiências vividas e habilidades, por exemplo) e aquelas construídas (demanda social, por exemplo) na sua interação com o ambiente (Bronfenbrenner \& Morris, 1998; Poleto \& Koller, 2008). Desta forma, pode-se pensar as propriedades da pessoa, como a cognição, e as características socioemocionais e motivacionais (De Antoni \& Koller, 2017).

Pode-se verificar, assim, como está a criança em relação ao ambiente em que ela está inserida, como sua capacidade de se relacionar, executar tarefas, compreender suas motivações. A "competência cognitiva" refere-se ao temperamento, ao caráter e à personalidade. Na infância, pode-se pensar em temperamento, visto que a personalidade está relacionada às crianças maiores e aos adultos. A continuidade do temperamento é expressa não por meio da constância do comportamento ao longo do tempo, mas associada à consistência nos modos pelos quais a pessoa comporta-se nos diferentes contextos, tanto proximais como os remotos nos quais vive (Bronfenbrenner, 1992).

Segundo Bronfenbrenner (1992), nenhuma característica da pessoa existe ou exerce influência no desenvolvimento de forma isolada. Cada qualidade é intrinsecamente envolvida e encontra seus significados e expressões em ambientes particulares, dos quais a família é o principal exemplo. Como resultado, há sempre um interjogo entre as características psicológicas da pessoa e as de um ambiente específico: uma não pode ser definida sem referência à outra.

Segundo Del Prette e Del Prette (2010), a infância é um período crítico para a aprendizagem das habilidades sociais e das normas de convivência, as quais ocorrem primeiro com a família e depois em outros ambientes, como vizinhança, préescola e escola. Além disso, o desenvolvimento das habilidades sociais na infância é percursor ao desenvolvimento de competência social em outras etapas no desenvolvimento. Muitos comportamentos, nessa faixa etária, são compreendidos como socialmente indesejados pelas mães, de acordo com estudo de Bolsoni-Silva, Marturano e Manfrinato (2005). Entre eles estão os comportamentos internalizantes, como queixar-se de dores, ficar agarrado à mãe, ou os externalizantes, como brigar, não obedecer, entre outros. E há a relação entre a manifestação de comportamentos indesejados e um déficit de habilidade social (De Antoni \& Koller, 2017).

Por isso, faz-se necessário que a criança conheça diferentes ambientes além da casa, como por exemplo, a escola e uma praça de lazer. As relações com outras 
crianças de diversas idades, além de importantes no seu processo de socialização, proporcionam o contato com as diversidades e permitem assim múltiplas experiências de vida.

O terceiro fator é o contexto, que é, para Bronfenbrenner (1996), a configuração ecológica que enfoca as características e as relações entre os vários sistemas nos quais a pessoa está inserida e se relaciona direta ou indiretamente. Essas estruturas são denominadas microssistema, mesossistema, exossistema e macrossistema. O microssistema inicial de toda criança é a família; nela a criança aprende a cuidar e ser cuidado, a se proteger e ser protegida. É também na família que ela deve aprender a desenvolver suas habilidades sociais, por meio da negociação, da expressão de sentimentos e dos processos de comunicação (De Antoni \& Koller, 2017).

Bronfenbrenner (2011) afirma que na díade mãe-filho é necessário uma terceira pessoa para funcionar efetivamente, de preferência outro adulto, não necessariamente o pai biológico ou adotivo, mas um parente ou outra pessoa comprometida com o sistema familiar. Outro fator importante, também apresentado anteriormente, é o quanto a falta de espaço físico adequado na comunidade atua como um fator de risco, pois as crianças ficam "presas" na residência, que é um ambiente também pequeno e com poucos estímulos, muitas vezes (De Antoni \& Koller, 2017).

Além disso, as trocas afetivas também são de suma importância para as crianças. Muitas famílias substituem o afeto amoroso por interações pautadas na agressividade (cobranças indevidas, agressão física, humilhação, entre outros), como uma forma de, pelo menos, se sentirem juntos, mas não unidos (De Antoni, 2012; De Antoni \& Koller, 2012; De Antoni, Baroni \& Koller, 2007). Desta forma, a confusão de papéis, os escassos momentos em que há o desempenho de atividades em conjunto e a falta de expressão amorosa são fatores preocupantes em um microssistema familiar. Assim, a agressividade de uma criança pode ser consequência desses fatores.

O macrossistema também pode influenciar os comportamentos agressivos. Ele é compreendido como o conjunto de crenças, valores e ideologias ligado a diversos aspectos, como política, filosofia, arte e religião (Bronfenbrenner, 2011). A mídia e a sociedade como um todo ainda reforçam e incentivam comportamentos violentos, associando-os à virilidade, ao exercício de poder, à masculinidade e à 
força. De alguma forma, essa cultura e subcultura são valorizadas em diversos espaços. Romper com esses padrões macrossistêmicos que ocorrem ao longo de gerações é mais difícil. Mas a consciência da existência sobre esse estereótipo pode auxiliar nessa mudança, bem como em uma cultura pela paz (De Antoni \& Koller, 2017).

A quarta dimensão da Teoria Bioecológica do Desenvolvimento Humano é o tempo. $\mathrm{O}$ cronossistema seria a sequência de eventos que constituem a história e as rotinas de uma pessoa (Bronfenbrenner, 1996). A dimensão temporal é analisada em três níveis: microtempo, mesotempo e macrotempo. Pode-se pensar, como exemplo de mesotempo, a importância de ocorrer dentro da rotina de uma criança atividades dirigidas e lúdicas, o estabelecimento de horários, regras de convivência. Em relação ao macrotempo, pode-se observar o momento histórico e político que a sociedade atravessa como um fator importante nas condições de diversas pessoas. O tempo flui pelas outras dimensões de análise e não pode e nem deve ser observado de forma isolada (De Antoni \& Koller, 2017).

A Teoria Bioecológica do Desenvolvimento Humano permite lançar um olhar além do comportamento manifesto. A criança é um reflexo de várias interações, que contribuem para constituir o que ela é e a forma como se comporta em sua ontogênese. Entretanto, tal teoria não possui uma visão determinista e inflexível sobre o ser humano. Pelo contrário, Bronfenbrenner (2011) postula que os seres humanos têm a possibilidade de tornar-se mais humanos. O contexto, apesar de ser uma construção histórica e social, também é passível de mudanças, e essas mudanças são propulsoras de um desenvolvimento que possibilite uma vida plena (De Antoni \& Koller, 2017).

Com isso, essa teoria preocupa-se em estudar o desenvolvimento humano, contextualizando-o. Qualquer criança que não esteja exposta a tantos fatores de risco, mas que apresente comportamentos agressivos, ou transgressores, pode também ser "olhada" por meio das lentes propostas por Bronfenbrenner. Esses comportamentos transgressores podem ser compreendidos pelo paradigma sistêmico, em que eles são mais que o somatório de diversos fatores associados presentes nas características da pessoa, na compreensão do seu processo e nos diferentes contextos na qual está inserida através do tempo (De Antoni \& Koller, 2017). 


\section{4- Objetivos:}

4.1 Objetivo geral: Investigar as relações das práticas educativas parentais e as características familiares presentes nos comportamentos transgressores das crianças de 3 a5 anos de duas Unidades Escolares públicas da $2^{\text {a }}$ Coordenadoria Regional de Educação (CRE) do município do Rio de Janeiro.

4.2 Objetivo específico I: Comparar as práticas educativas parentais e o perfil comportamental transgressor das crianças de 3 a 5 anos a partir do relato dos professores.

4.3 Objetivo específico II: Investigar a relação entre as práticas educativas parentais e as características sociodemográficas dos pais.

4.4 Objetivo específico III: Comparar os níveis de clima familiar e o comportamento das crianças de 3 a 5 anos relatado pelos professores.

\section{5- Método:}

5.1 Cuidados éticos: A pesquisa realizada atendeu as normas da Comissão Nacional de ética em Pesquisa (CONEP, Conselho Nacional de Saúde, Ministério da Saúde, Brasil) e o Código de Ética Profissional dos Psicólogos. Por se tratar de uma pesquisa envolvendo seres humanos, esta investigação foi cuidadosamente elaborada visando atender às exigências estabelecidas pela Resolução 196/96 do Conselho Nacional de Saúde e seus desdobramentos. Será submetida ao Comitê de Ética em Pesquisa da Pontifícia Universidade Católica do Rio de Janeiro e da Secretaria Municipal de Educação do Rio de Janeiro.

5.2 Participantes: Participaram desta pesquisa 50 pais/mães de crianças de 3 a 5 anos e 6 professoras de duas Unidades Escolares pública da $2^{\text {a }} \mathrm{CRE}$ do município do Rio de Janeiro. 


\section{ESCOLARIDADE}

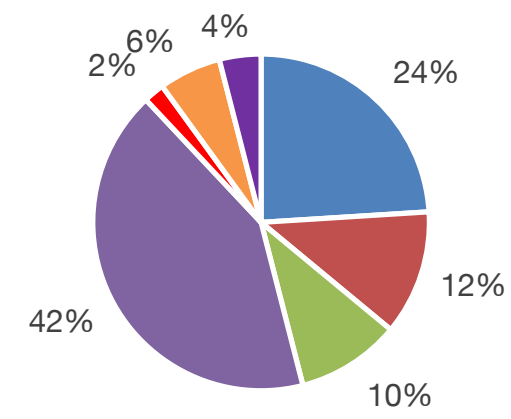

- Ens. Fund. Incompleto - Ens. Fund. Completo - Ens. Médio Incompleto

- Ens. Médio Completo -Superior Incompleto -Superior Cursando

- Superior Completo

ráfico 1: Percentual de escolaridade de todos os pais

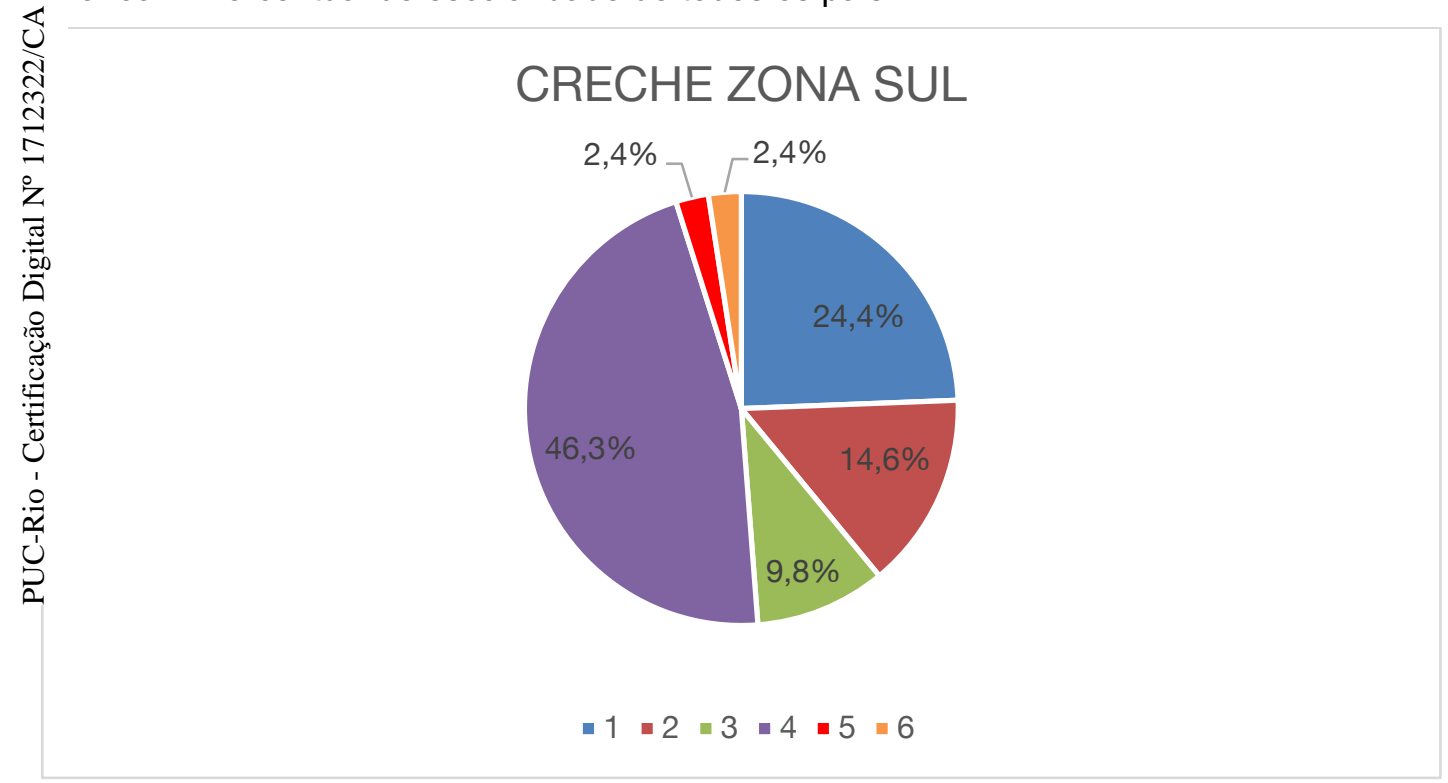

Gráfico 2: Percentual de escolaridade pais creche Zona Sul 


\section{EDI ZONA NORTE}

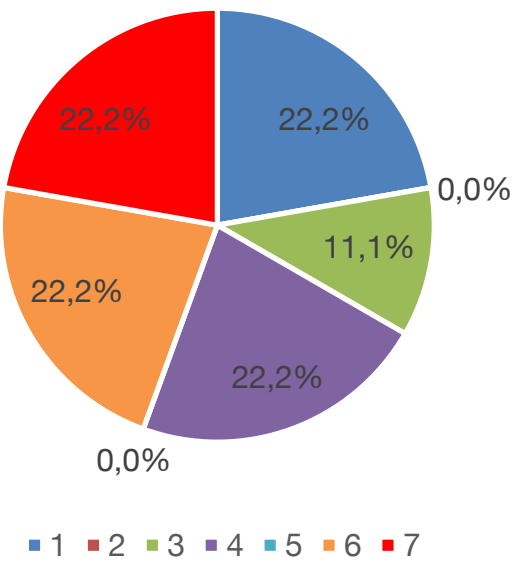

Gráfico 3: Percentual de escolaridade pais EDI Zona Norte

Nota-se no gráfico 1 o percentual de escolaridade presente nos participantes dessa tese. Com isso, tem-se 2\% dos participantes com ensino Superior Incompleto, $4 \%$ com Superior Completo e 6\% com Superior Cursando. Além disso, tem-se 42\% com Ensino Médio Completo e 10\% com Ensino Médio Incompleto. Com relação ao Ensino Fundamental, tem-se 24\% com ele Incompleto e 12\% com ele Completo.

\begin{tabular}{|l|l|}
\hline CRECHE ZONA SUL & EDI ZONA NORTE \\
\hline TURMA 1: 12 crianças de 3 a 4 anos & TURMA 6: 9 crianças 4 a 5 anos \\
\hline TURMA $2: 5$ crianças de 3 anos & \\
\hline TURMA $3: 12$ crianças de 4 a 5 anos & \\
\hline TURMA $4: 6$ crianças de 3 anos & \\
\hline TURMA 5: 6 crianças de 3 a 4 anos & \\
\hline
\end{tabular}

Tabela 1: Divisão de crianças $\mathrm{x}$ turma.

Nesta tabela pode-se perceber que seis turmas diferentes participaram da pesquisa e assim, contou-se com uma professora de cada turma para responder a entrevista referente as crianças, totalizando seis professoras. 


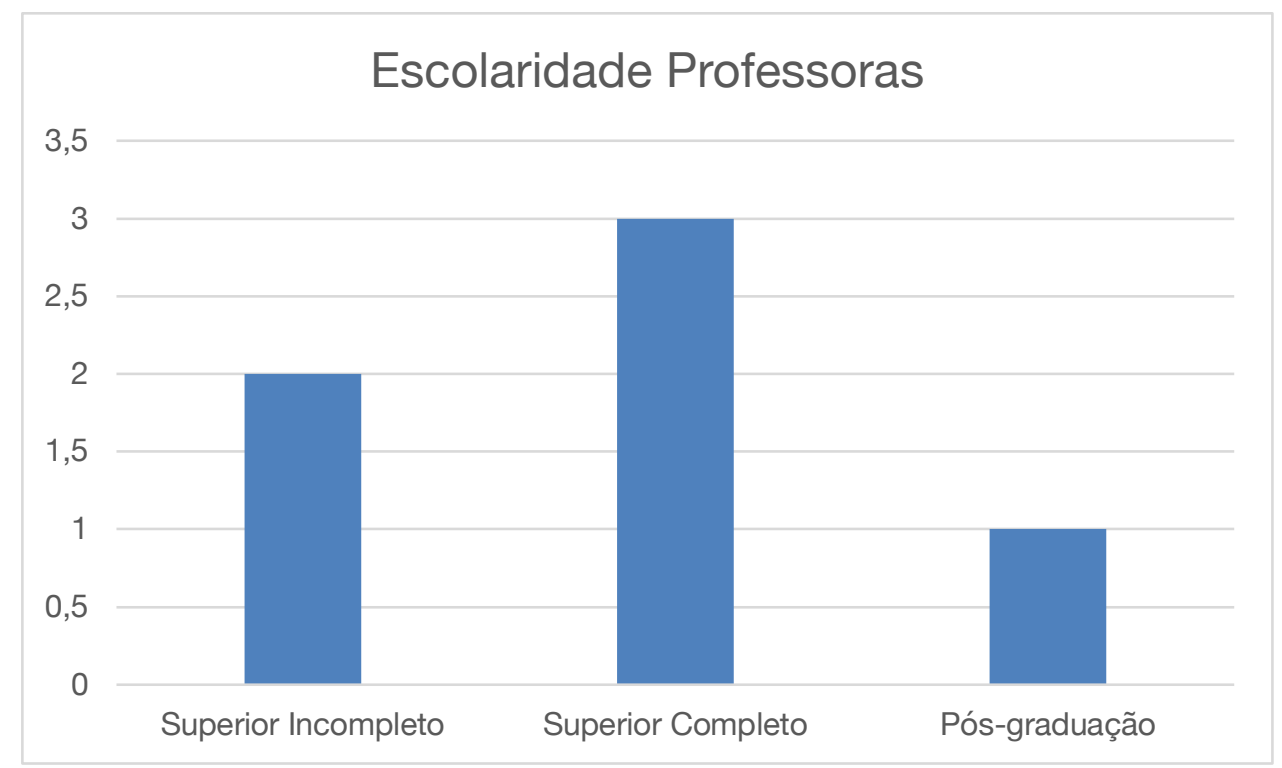

Gráfico 4: Percentual de escolaridade das professoras

Nota-se, neste gráfico, que a maioria das professoras apresenta o nível de escolaridade Superior Completo, uma com pós-graduação e as duas de nível Superior Incompleto estão cursando a faculdade de Pedagogia.

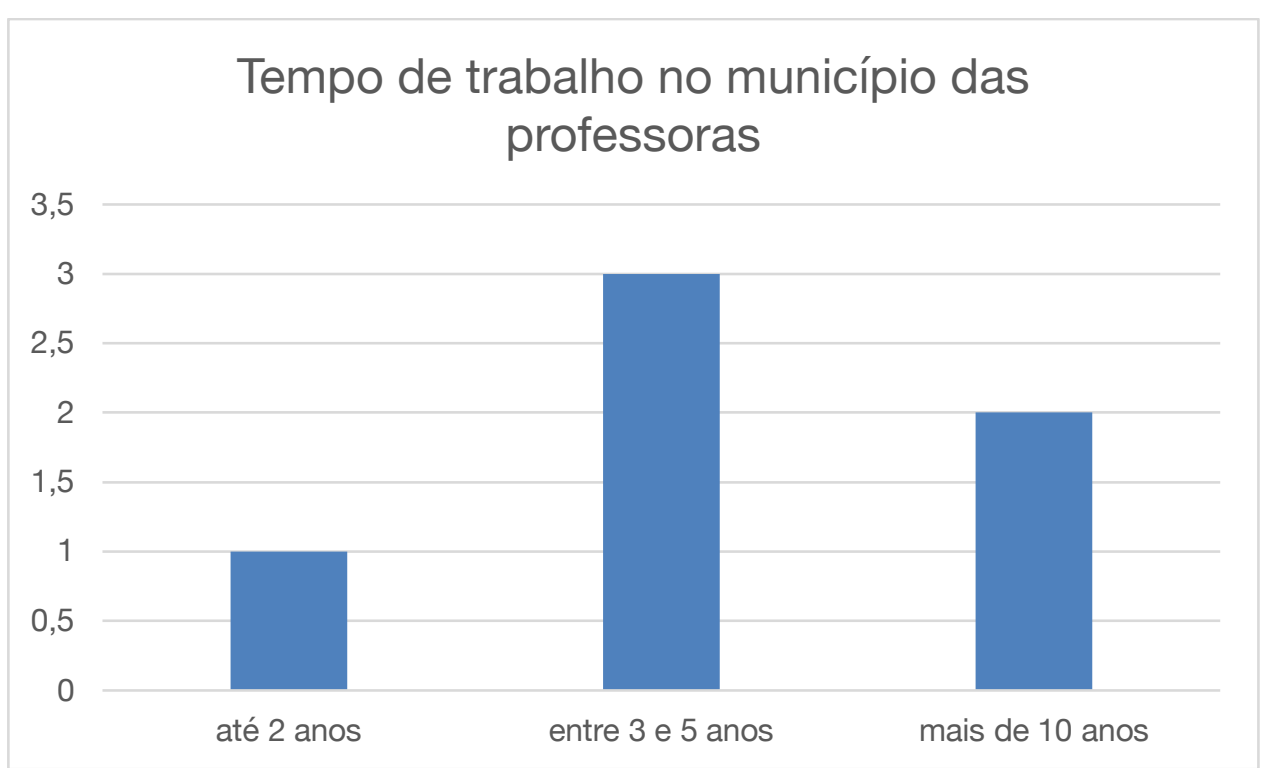

Gráfico 5: Percentual de tempo trabalho das professoras na rede municipal do Rio de Janeiro

Nota-se neste gráfico que a maioria das professoras participantes não está há muito tempo na rede municipal, tendo três entre 3 e 5 anos e uma com até dois anos de experiência. Apenas duas professoras estão com mais de 10 anos na rede municipal. 


\subsection{Instrumentos:}

Para os pais:

1. Termo de Consentimento Livre Esclarecido.

2. Inventário Sociodemográfico com perguntas referentes a idade, escolaridade e profissão.

3. Inventário do Clima Familiar - ICF (Teodoro et al., 2009). O ICF é composto de 22 itens que avaliam a percepção dos pais acerca das características das relações familiares a partir de quatro fatores: conflito (ex.: "Os conflitos são comuns"), hierarquia (ex.: "É comum que algumas pessoas proíbam outras de fazer determinadas coisas sem explicar o porquê"); apoio (ex.: "Procuramos ajudar as pessoas da nossa família quando percebemos que estão com problemas") e coesão (ex.: "As pessoas sentem-se felizes quando toda a família está reunida").

Para os professores:

1. Termo de Consentimento Livre Esclarecido.

2. Inventário Sociodemográfico com perguntas referentes a idade, tempo de trabalho como professor e escolaridade.

3. Entrevista dirigida. 


\subsection{Procedimentos:}

Após aprovação no Comitê de Ética da Pontifícia Universidade Católica do Rio de Janeiro e na prefeitura do Rio de Janeiro, foi feito o contato presencial em creches e Espaços de Desenvolvimento Infantil (EDI) da $2^{\text {a }}$ CRE do município do Rio de Janeiro. Inicialmente foi apresentado o projeto às diretoras, em seguida, às professoras e, sequencialmente, aos pais. Os instrumentos foram apresentados e uma vez tendo seu aceite para participação na pesquisa, o Termo de Consentimento Livre e Esclarecido foi assinado e iniciou-se o preenchimento dos instrumentos.

Coleta de dados:

Os participantes indicados pela direção e aptos a participarem da pesquisa foram contactados presencialmente. Nesse momento, a pesquisa foi explicada e quando houve a concordância por parte dos pais e professoras em participar, foi marcado um encontro no melhor dia, horário e local para o participante. Nessa ocasião, foram explicados mais detalhadamente os objetivos e métodos da pesquisa, assinado o Termo de Consentimento Livre e Esclarecido e a aplicação dos instrumentos foi realizada, assim como a aplicação da entrevista. Os participantes preencheram individualmente os instrumentos e a ficha de dados sociodemográficos.

Análise dos dados:

Todos os dados foram tratados descritivamente (frequências, médias, medidas de variância) e analisados estatisticamente, através de testes paramétricos (escalas e variáveis contínuas) e não paramétricos (frequências e variáveis categóricas).

Com o objetivo de avaliar a frequência das palavras apresentadas no discurso dos participantes e para a análise e interpretação dos dados obtidos, foi utilizado o software IRaMuTeQ. Este possibilita a realização de diferentes tipos de análises estatísticas sobre corpus textuais e tabelas indivíduos/palavras (Camargo \& Justo, 2013).

Inicialmente, o corpus textual foi preparado para a análise criando-se, no software Libre Office, um arquivo único de texto com todas as entrevistas realiza- 
das. A primeira linha tem que ser pulada para separar os textos com linhas de comando. As linhas são monotemáticas, garantindo uma melhor compreensão dos dados coletados. Posteriormente, o arquivo foi revisado e corrigido, seguindo as indicações do software para uma melhor utilização do mesmo (Camargo \& Justo, 2013).

Após a preparação do corpus, foi realizada uma análise lexicográfica para calcular a frequência das palavras; uma classificação hierárquica descendente (CHD), obtendo classes que apresentam vocabulários semelhantes entre si. Uma análise de similitude, para identificar as co-ocorrências entre as palavras e as indicações de conexidades entre elas foi realizada. Por fim, foi gerada uma nuvem de palavras, que agrupa e organiza, graficamente, as palavras em função de sua frequência (Camargo \& Justo, 2013). 


\section{6- Resultados e discussões}

Dentro dos objetivos específicos propostos por essa tese, um deles buscou investigar a relação entre as práticas educativas parentais e as características sociodemográficas dos pais. A partir daí, produziu-se um gráfico que mostra o percentual das escolaridades apresentadas anteriormente nesse estudo.

Nota-se que o maior percentual para escolaridade foi Ensino Médio Completo, com a informação de $42 \%$ dos pais e mães que responderam a pesquisa. Todavia, pode-se perceber que o segundo nível de escolaridade de maior percentual foi o de Ensino Fundamental Incompleto, caracterizando 24\% dos pais e mães. Além disso, encontra-se um maior número de pessoas com nível de escolaridade anterior ao Ensino Médio do que posterior a ele.

Percebe-se que os dados sociodemográficos encontrados neste estudo corroboram com as pesquisas apresentadas por Almeida e Vasconcellos (2018), em que, na grande maioria das famílias de baixa renda ou pobres, os membros começam a trabalhar cedo e não terminam seus estudos. As mulheres, por exemplo, encontram-se como chefes de família atualmente, o que significa que trabalham fora de casa. Além disso, no caso das famílias de baixa renda, têm-se, também, muitos casos de gravidez na adolescência. Ambos os exemplos podem ser percursores para que ocorra o abandono dos estudos, pois faz-se necessário cuidar da criança ou começar a trabalhar para ajudar nas despesas, como mostram os dados do IBGE de 2016.

A família sofreu profundas mudanças ao longo do tempo, como já apresentado anteriormente, devido a fatores econômicos, históricos, sociais e culturais, que consequentemente repercurtiram nas relações de seus membros. Neste dado, podese trazer a relação entre a família contemporânea e a família patriarcal do Brasil Colônia, pois neste caso, ela apresentava grande extensão e era composta por membros consaguíneos ou não, que circulavam livremente no seio familiar. Tal modelo familiar existe ainda hoje na sociedade brasileira, e um exemplo dele é a realidade que se encontram as favelas do Rio de Janeiro. Um fator desse modelo de família patriarcal que se percebe uma mudança é o referente ao pai como figura incontes- 
tável de autoridade. Hoje, as famílias apresentam muitas mulheres como suas chefes, mas há ainda algumas que seguem totalmente o modelo patriarcal (Almeida \& Vasconcellos, 2018).

Logo, alguns fatores fazem com que ocorram mudanças e ajustamentos na família, como, por exemplo, a espera de um bebê. Com isso, lembra-se o sistema dinâmico traçado por Harkness e Super (1994). Neste dado, consegue-se perceber essa forma de pensar a família, pois há uma nova organização familiar com a chegada de um bebê.

Além disso, o IBGE (2009) apresenta dados sobre a postergação da nupcialidade, o aumento das famílias monoparentais, a diminuição da disponibilidade de tempo e o excesso de individualismo que geram mudanças nas relações no interior das famílias. Ou seja, mais um fator que justifica os dados encontrados na questão referente à análise sociodemográfica.

O corpus geral das entrevistas foi constituído por 50 textos, que representam as 50 entrevistas realizadas na pesquisa. Emergiram 8.745 ocorrências (preposições, palavras, formas ou vocabulários), sendo 1094 palavras distintas e 171.047 palavras com uma única ocorrência.

O Iramuteq, quando faz a análise do corpus de texto, mostra um resumo desse corpus, conforme formato da figura 1. Quando ele diz que encontrou 50 números de textos, mostra que todas as entrevistas cadastradas no software foram lidas. As ocorrências representam todas as palavras escritas no documento que foi posto no Iramuteq. Nessas ocorrências, tem-se a possibilidade, dentro do software, de decidir quais palavras serão ativas, por exemplo. Nesse caso, foram ativos os adjetivos e, de forma suplementar, os advérbios e artigos. 


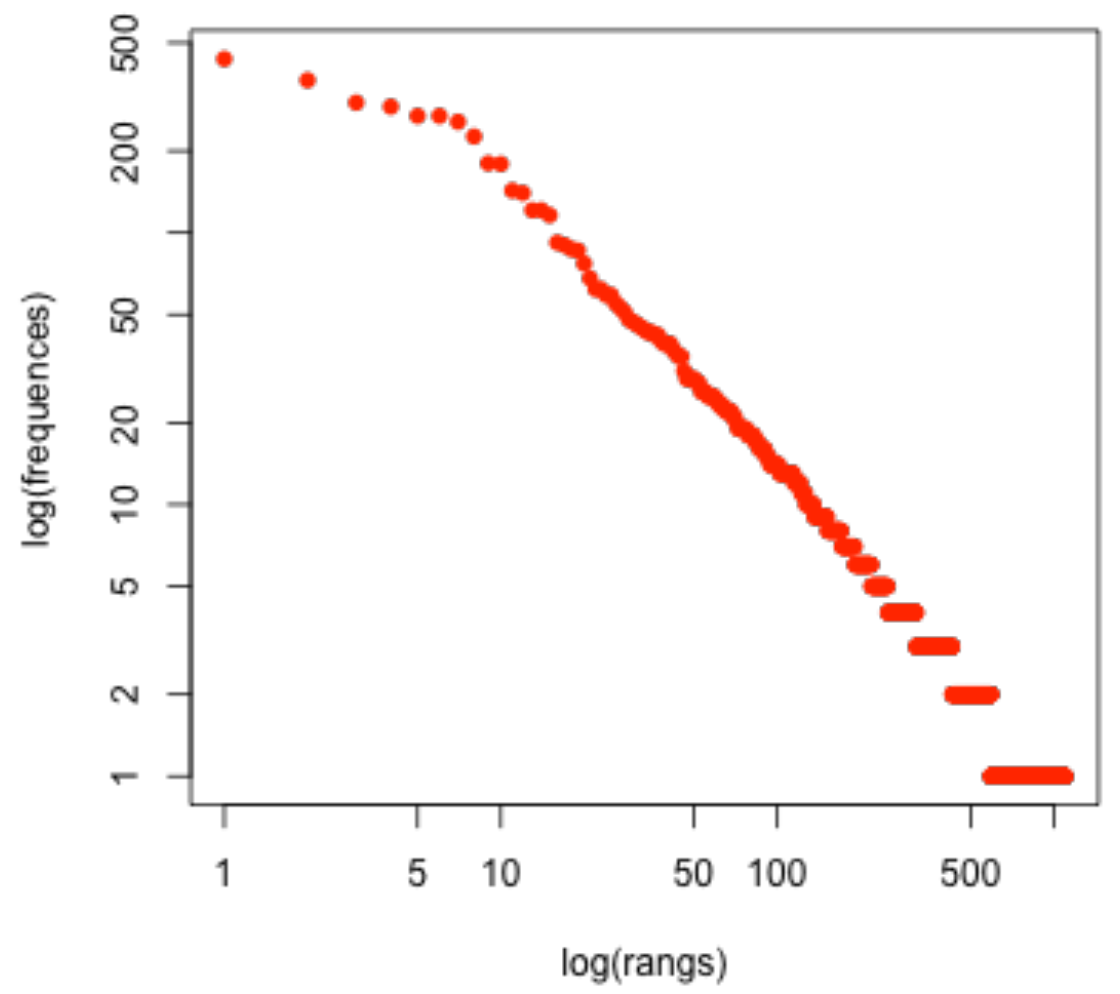

Figura 1 - Frequência de palavras $X$ repetição de palavras.

A figura 1 demonstra, do lado esquerdo (Frequência), as palavras que emergiram do corpus e que se repetiram apenas uma vez, enquanto o lado direito (Variância), revelou as palavras que se repetiram muitas vezes dentro do corpus textual.

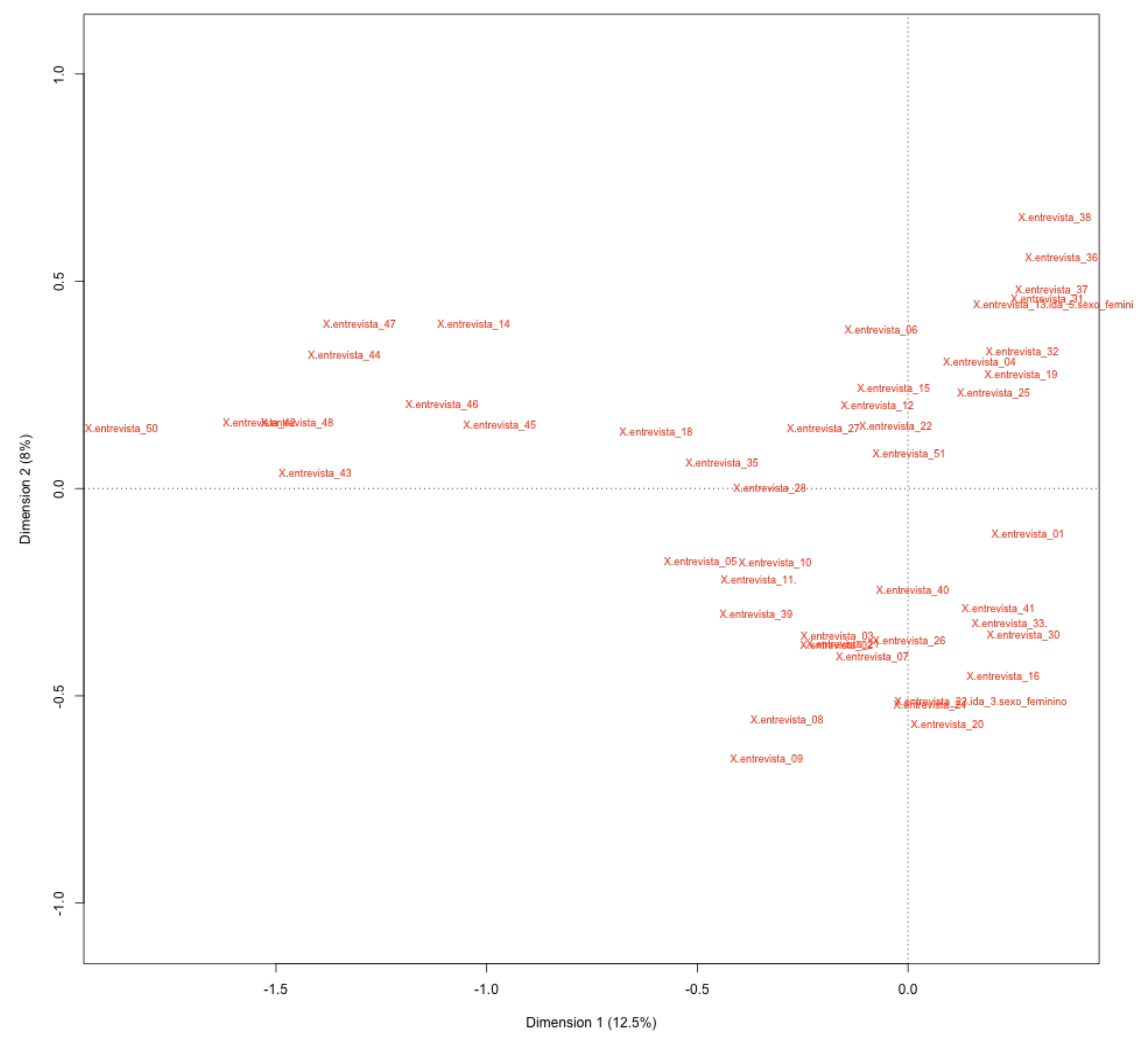


Figura 2 - Frequência de palavras X repetição de palavras (aumentado)

Nota-se, na figura 2, de forma mais detalhada, a frequência de palavras x repetição de palavras produzidas pelas entrevistas.

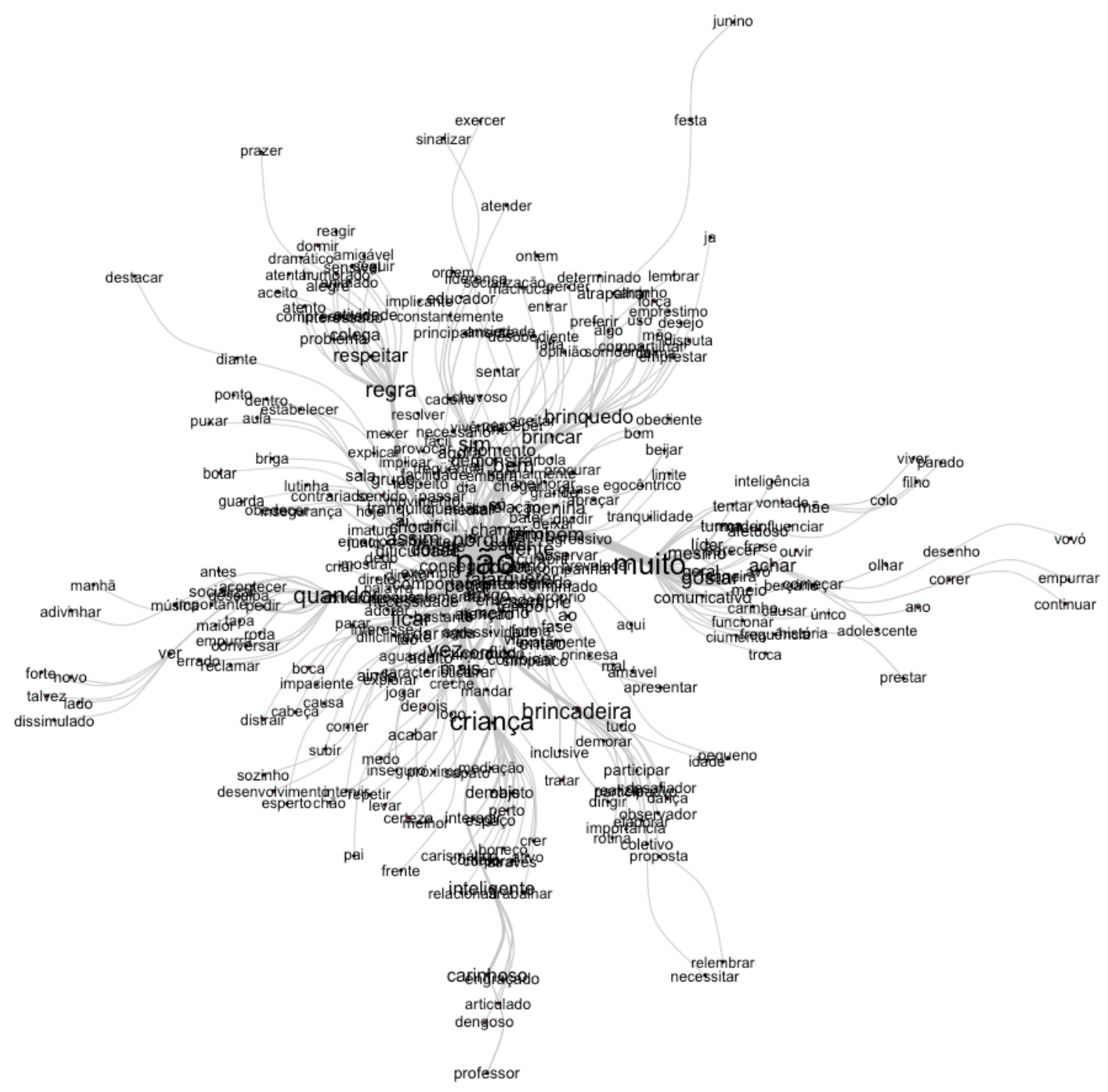

Figura 3 - Árvore de palavras de todas as entrevistas

Nesta figura, pode-se notar que algumas palavras se destacam: não, muito, criança, regra e brincadeira. Com isso, é possível perceber quais palavras durante 
as entrevistas se relacionaram ao comportamento das crianças nos espaços da escola.

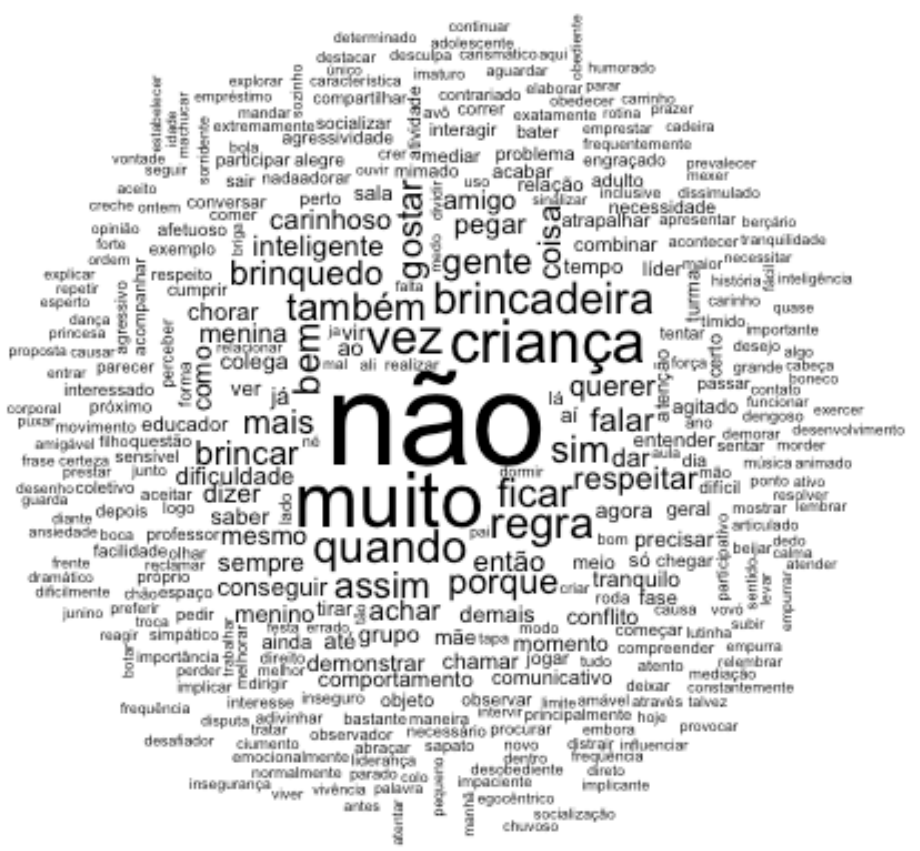

Figura 4: Nuvem de palavras de todas as entrevistas

$\mathrm{Na}$ figura 4, pode-se perceber que na nuvem de palavras destacam-se outras palavras, como: querer, falar, sim, respeitar, porque, quando, assim, gostar e brinquedo.

Devido ao elevado números de palavras ao longo das entrevistas, decidiuse, para uma melhor percepção, realizar a análise de cada pergunta feita na entrevista. 


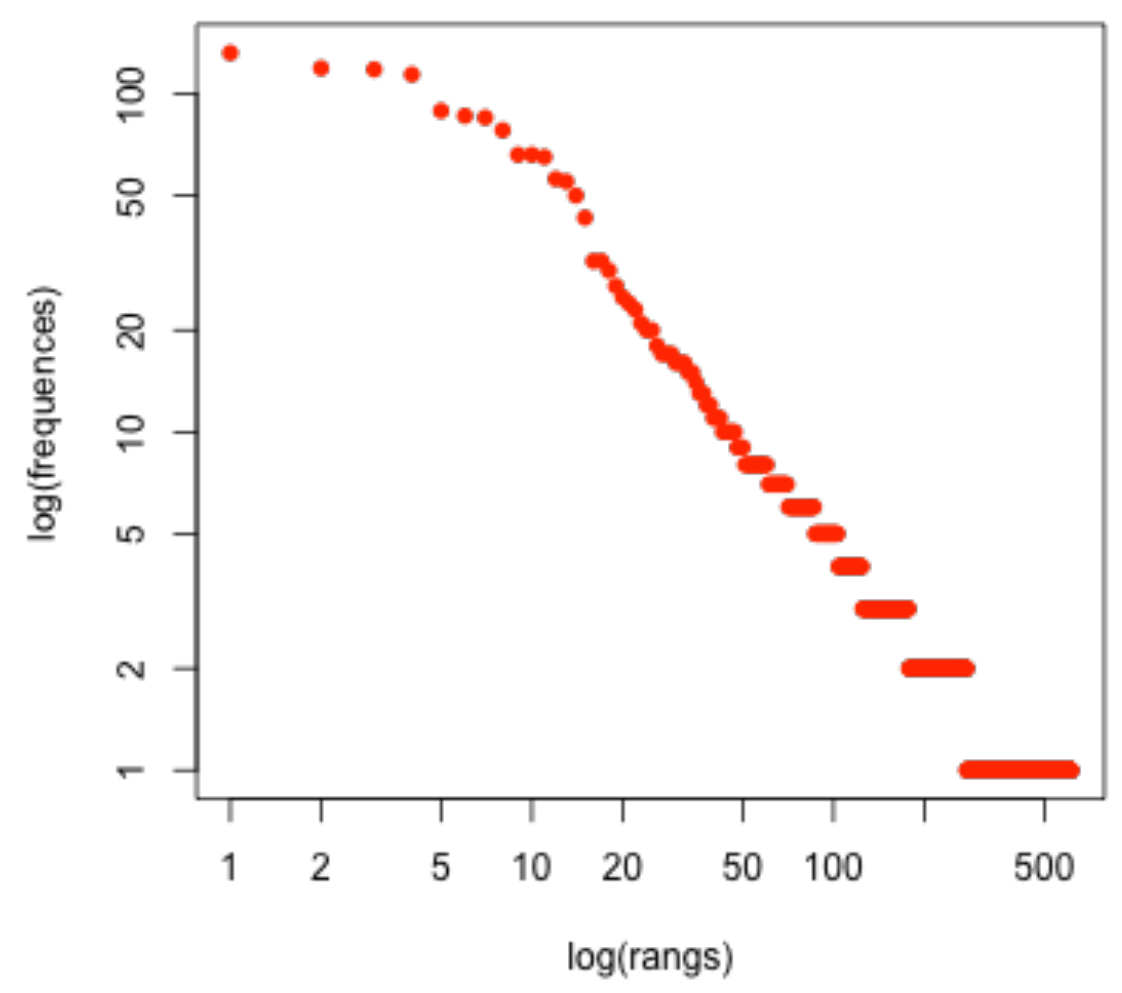

Figura 5: Frequência de palavras $X$ repetição de palavras (Pergunta 1: Descreva o comportamento dessa criança nos momentos de socialização com seus pares.)

Nesta análise, foram obtidos 50 números de textos que representam as 50 entrevistas realizadas, com 2905 ocorrências de palavras, isto é, o total de palavras presentes em todo texto. Sendo 612 formas, estas são o número de formas presentes no texto (palavras ativas e suplementares).

Além disso, 336 número de hápax, ou seja, número de palavras que aparecem apenas uma vez em todo texto. Foram obtidos $60,52 \%$ de ocorrências de palavras por texto, o que representa a razão entre o número de ocorrências pelo número de texto. 

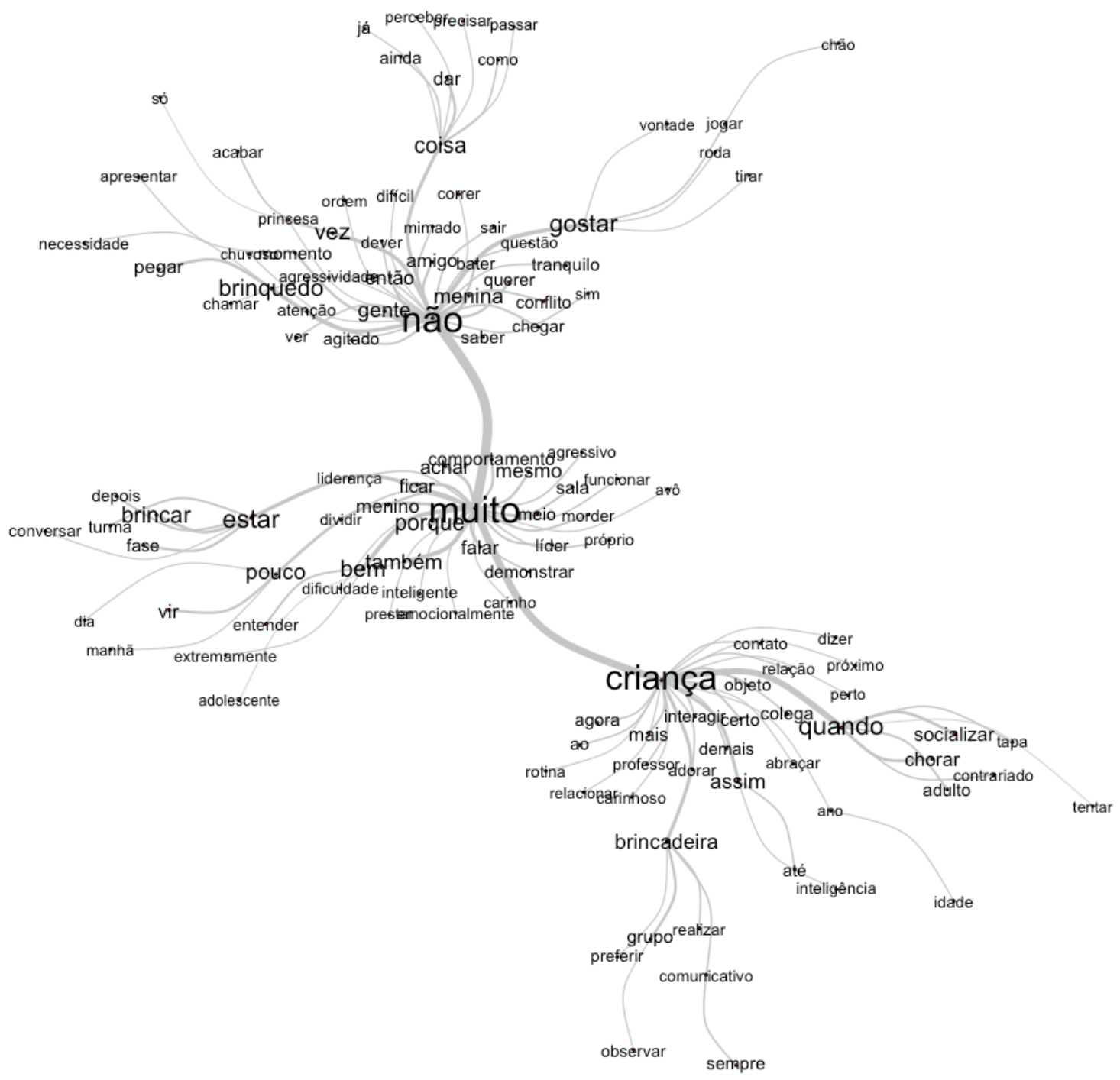

Figura 6: Árvore de palavras a partir da pergunta 1(Pergunta 1: Descreva o comportamento dessa criança nos momentos de socialização com seus pares.)

Nota-se, nesta árvore, três pilares que vão se enraizando por outros caminhos. São eles: criança, muito e não. Nesta pergunta, há muitas respostas possíveis, por isso, pode-se perceber muitas palavras e poucas repetições. Contudo, foi possível identificar que não houve uma palavra referente à transgressão ou à agressividade. Apenas em uma das ramificações de crianças tem-se a palavra idade. 


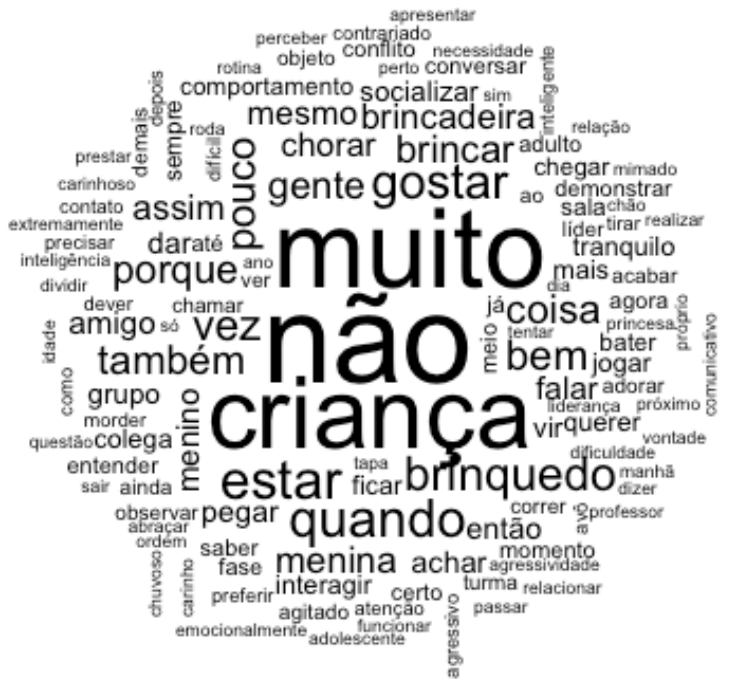

Figura 7: Nuvem de palavras referente a pergunta 1(Pergunta 1: Descreva o comportamento dessa criança nos momentos de socialização com seus pares.)

Quando observa-se a nuvem de palavras, em relação a pergunta 1, identifica-se a palavra agressivo, apesar de permanecer em evidência as palavras: muito, não, criança, estar, brinquedo, gostar, pouco, chorar, vez e também. Desta forma, é possível pensar que naquele espaço da escola, as crianças não demonstram fortemente comportamentos agressivos ou transgressores.

Com isso, pode-se refletir sobre as teorias de Bronfenbrenner (1996) e Harkeness e Super (1994), em que os autores ressaltam a influência do contexto nas ações e nos comportamentos das pessoas nele inseridas. Logo, lembra-se dos diferentes sistemas que as pessoas fazem parte desde o seu nascimento até sua morte. Bronfenbrenner (1996) enfatiza que todos os sistemas são interligados diretamente ou indiretamente. Sendo assim, considera-se que tanto os ambientes da escola como 
os da casa podem influenciar nos comportamentos da criança. Além disso, acrescentando os estudos de Harkness e Super (1994) referentes ao conceito de nicho de desenvolvimento, trazer o espaço da escola faz-se pertinente, principalmente em relação ao espaço da sala de aula em que as crianças interagem com as professoras. Estas possuem suas próprias crenças, normas e valores, e vão influenciar no comportamento das crianças. O comportamento, neste recorte da pesquisa, a princípio, não está sendo identificado como um comportamento agressivo ou transgressor na maioria das vezes.

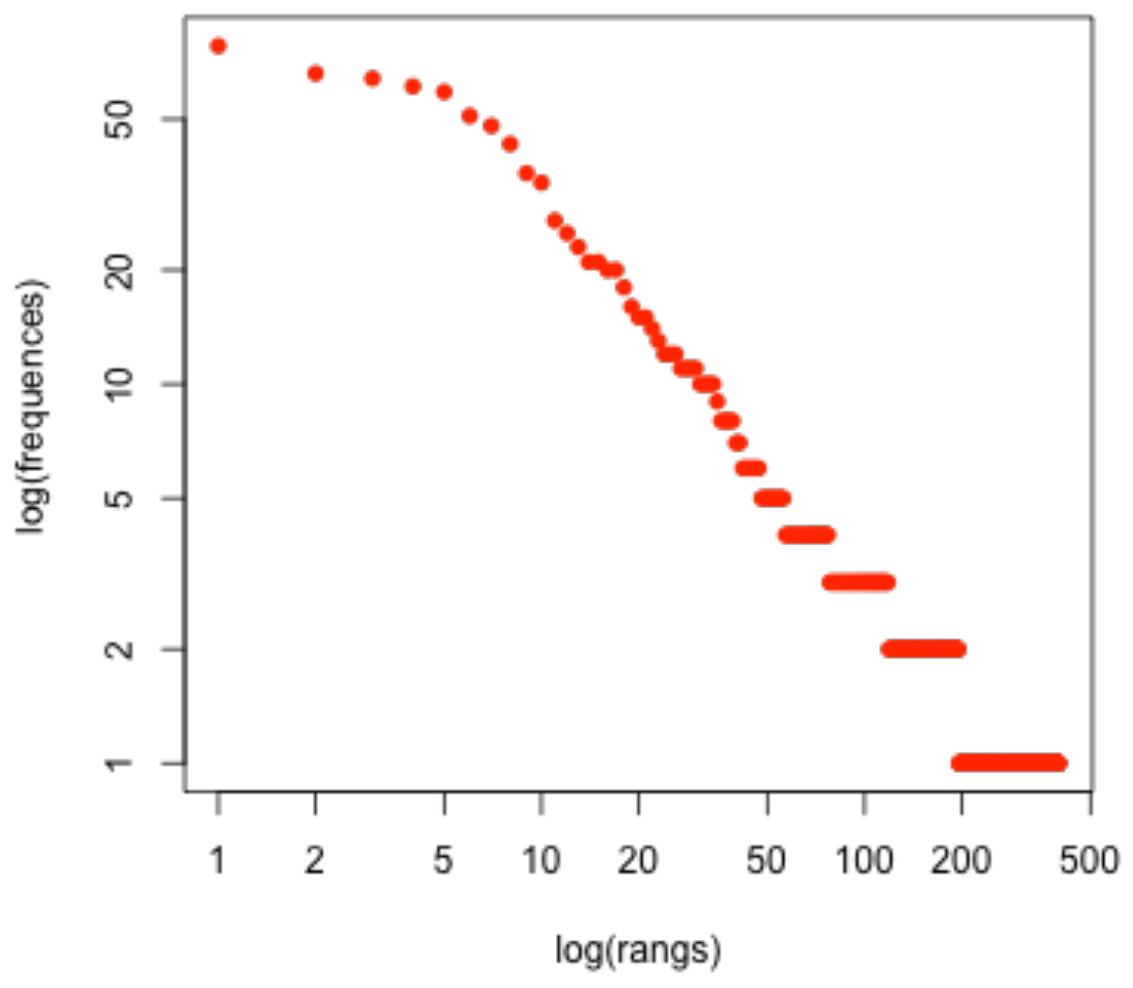

Figura 8: Frequência de palavras $X$ repetição de palavras (Pergunta 2: Há necessidade de mediar conflitos dessa criança com outras frequentemente? )

Neste gráfico, foi obtido 50 número de textos que representam as 50 entrevistas realizadas com 1609 ocorrências de palavras, isto é, o número total de palavras contidas no texto, sendo 399 formas que são o número de formas presentes no texto (palavras ativas e suplementares). Além disso, 204 números de hápax. Foram obtidos também $31.55 \%$ de ocorrências de palavras por texto, o que representa a razão entre o número de ocorrências e o número de textos. 


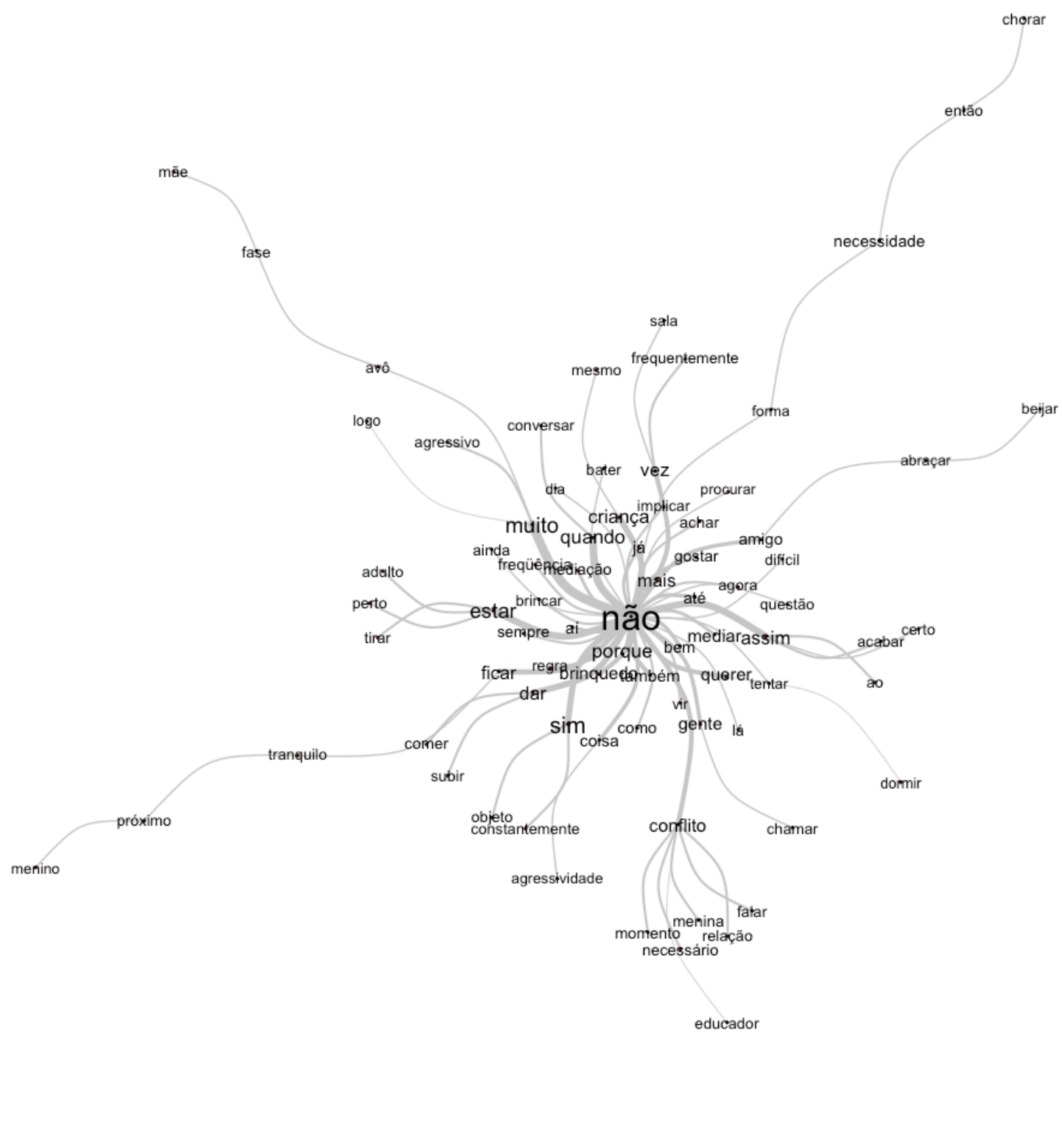

Figura 9: Árvore de palavras referente a pergunta 2 (Pergunta 2: Há necessidade de mediar conflitos dessa criança com outras frequentemente? )

Percebe-se, claramente, que por essa pergunta ser mais objetiva, a maioria das professoras respondeu que não, ou seja, que não há necessidade de mediar conflitos com frequência entre as crianças. $\mathrm{O}$ que reforça as informações presentes nas análises da pergunta 1 , em que também não foram identificadas referências a comportamentos agressivos ou transgressores. Acredita-se que, se os mesmos fossem comuns, na pergunta 2 , teríamos um número significativo de afirmações referentes à mediação de conflitos. 


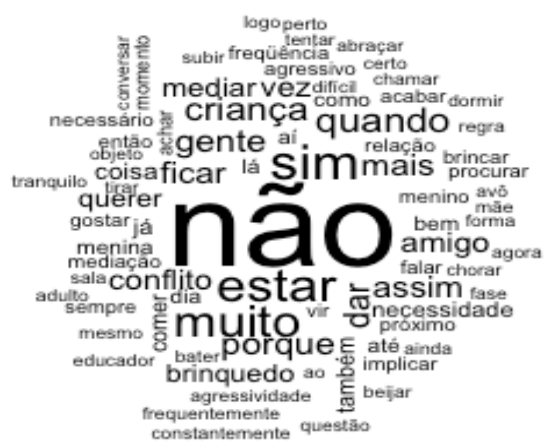

Figura 10: Nuvem de palavras referente a pergunta 2 (Pergunta 2: Há necessidade de mediar conflitos dessa criança com outras frequentemente?)

Nota-se na nuvem a presença da palavra sim em menor frequência que a palavra não. Apesar de não ser possível afirmar que, nessa amostra, encontram-se apenas crianças que não precisavam de mediações de conflitos, identificou-se que a maioria das crianças que foram observadas pelas professoras não necessitam de tal mediação com frequência. 


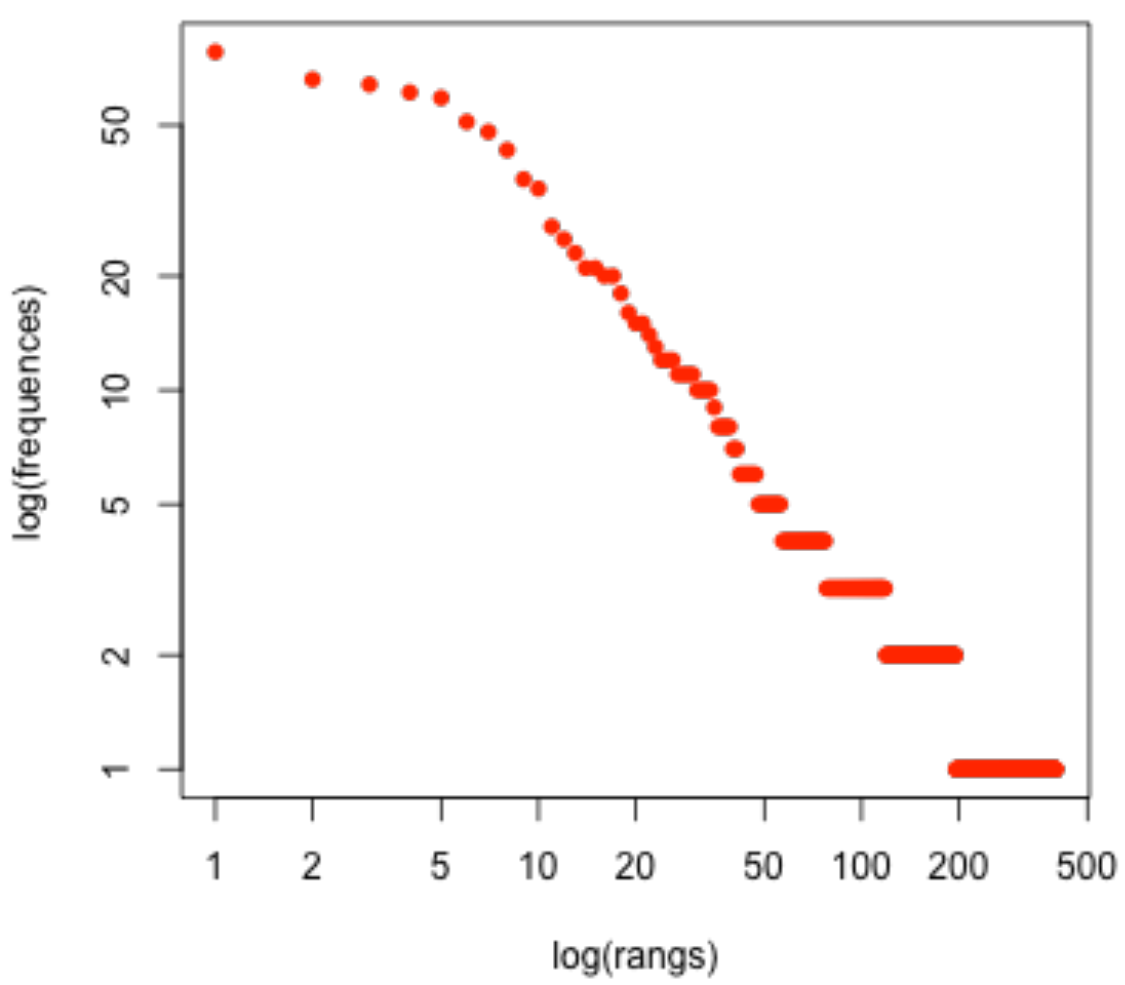

Figura 11: Frequência de palavras $X$ repetição de palavras pergunta 3 (Pergunta 3: Essa criança consegue respeitar as regras gerais da turma com facilidade?)

Nesta questão, foram obtidos 50 número de textos que representam as 50 entrevistas realizadas com 1.579 ocorrências de palavras, isto é, o número total de palavras contidas no texto, sendo 373 formas que são o número de formas presentes no texto (palavras ativas e suplementares).

Além disso, existem 197 números de hápax. Foram obtidos também 30.96\% de média de ocorrência de palavras por texto, o que representa a razão entre o número de ocorrências e o número de textos. 


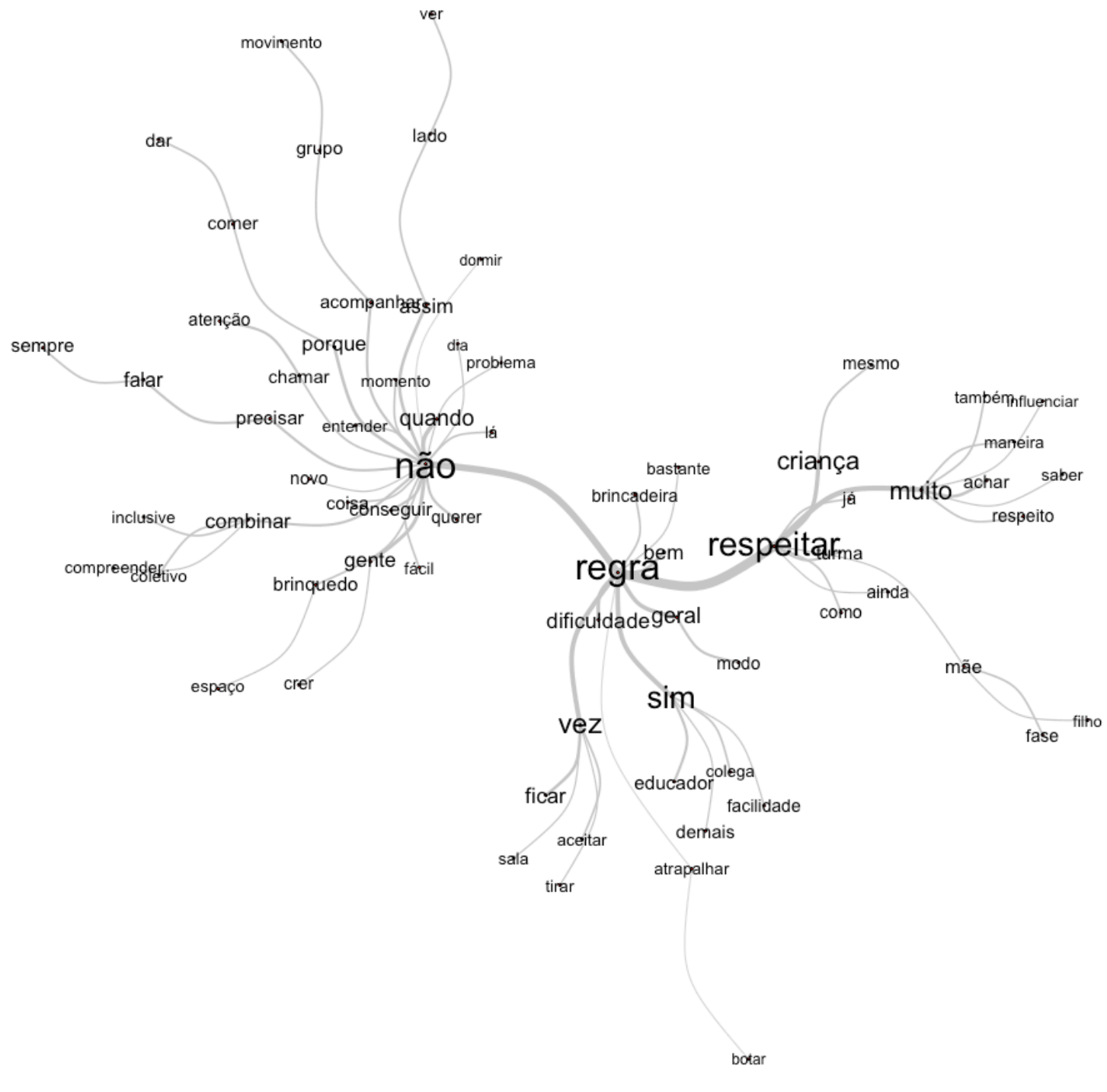

Figura 12: Árvore de palavras referente a pergunta 3 (Pergunta 3: Essa criança consegue respeitar as regras gerais da turma com facilidade?)

Nestas respostas, as professoras relatam, em sua maioria, que as crianças não conseguem respeitar as regras com facilidade. Com isso, ficamos com três polos de palavras: não, regra e respeitar.

A partir desses relatos, pode-se pensar acerca do que as professoras entendem como regra e se isso foi colocado claramente para as crianças. Friedlmeier, Schäfermeier, Vasconcellos e Trommsdorff (2007) afirmam, acerca da prática das professoras, que é possível discutir quais os valores em geral elas apresentam e como esses valores se manifestam em suas práticas. Pois quando observa-se que a 
maior parte das crianças não estão conseguindo respeitar as regras da turma, faz-se necessário considerar quais foram as práticas utilizadas pelas professoras, suas es-

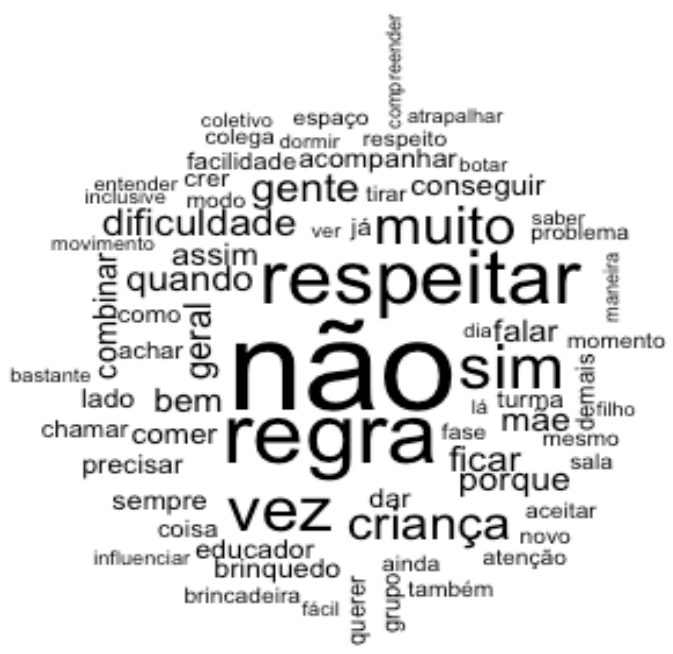

tratégias e se essas regras foram claramente explicadas e apresentadas às crianças. Figura 13: Nuvem de palavras referente a pergunta 3 (Pergunta 3: Essa criança consegue respeitar as regras gerais da turma com facilidade?)

Nesta nuvem, pode-se perceber, assim como também identificado nas perguntas anteriores, a palavra sim mais evidente. Em todo caso, ainda se apresentam com maior nitidez as palavras não, respeitar e regra. 


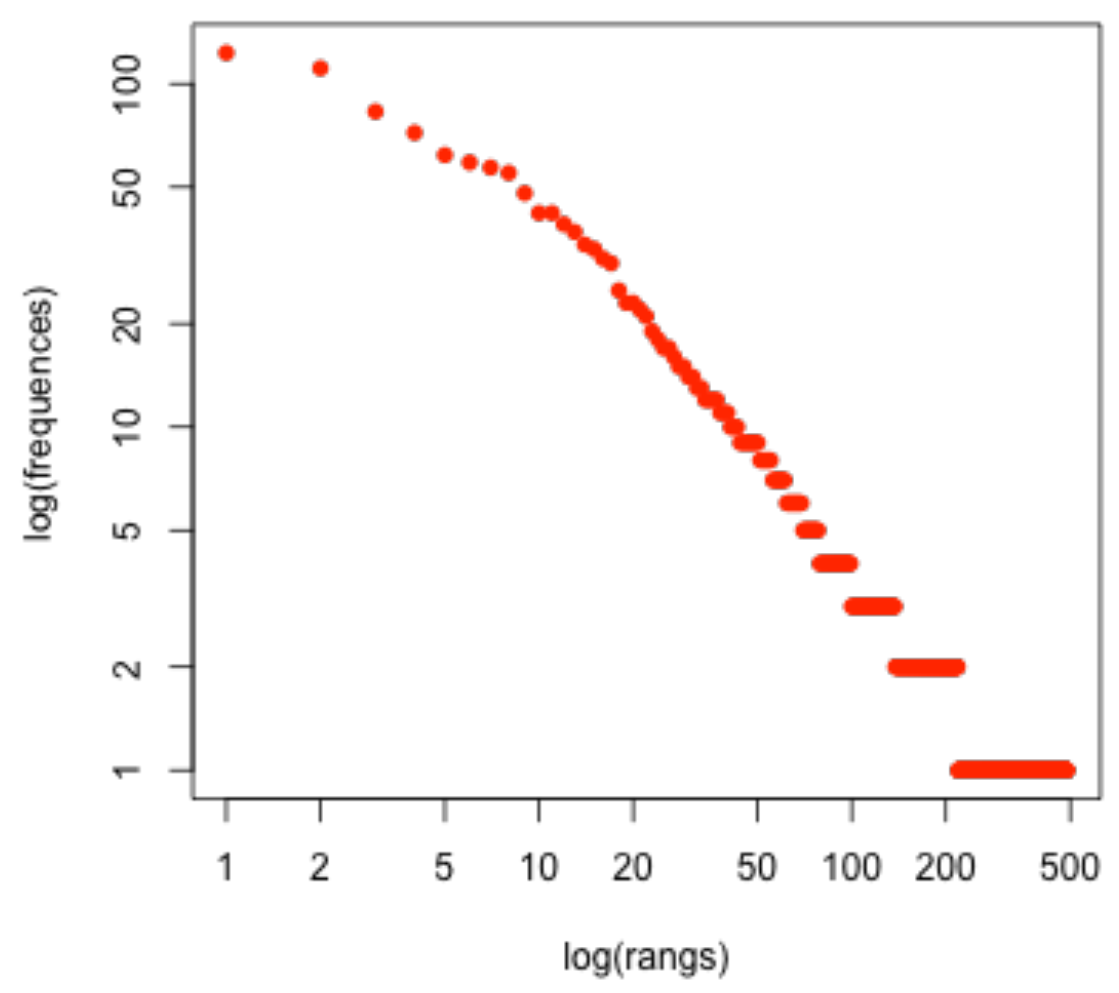

Figura 14: Frequência de palavras $X$ repetição de palavras pergunta 4 (Pergunta 4:Você conseguiria descrever, a partir das observações no dia a dia dessa criança, como é, em situações de brincadeiras em que algumas regras são estabelecidas previamente, o comportamento dessa criança, especificamente nesses momentos interativos?)

Nesta questão, foram encontrados 50 número de textos que representam as 50 entrevistas realizadas com 2.221 ocorrências de palavras, isto é, o número total de palavras contidas no texto, sendo 487 formas que são o número de formas presentes no texto (palavras ativas e suplementares).

Além disso, há 269 número de hápax. Foram obtidos também 43.55\% de média de ocorrências de palavras por texto, o que representa a razão entre o número de ocorrências e o número de textos. 


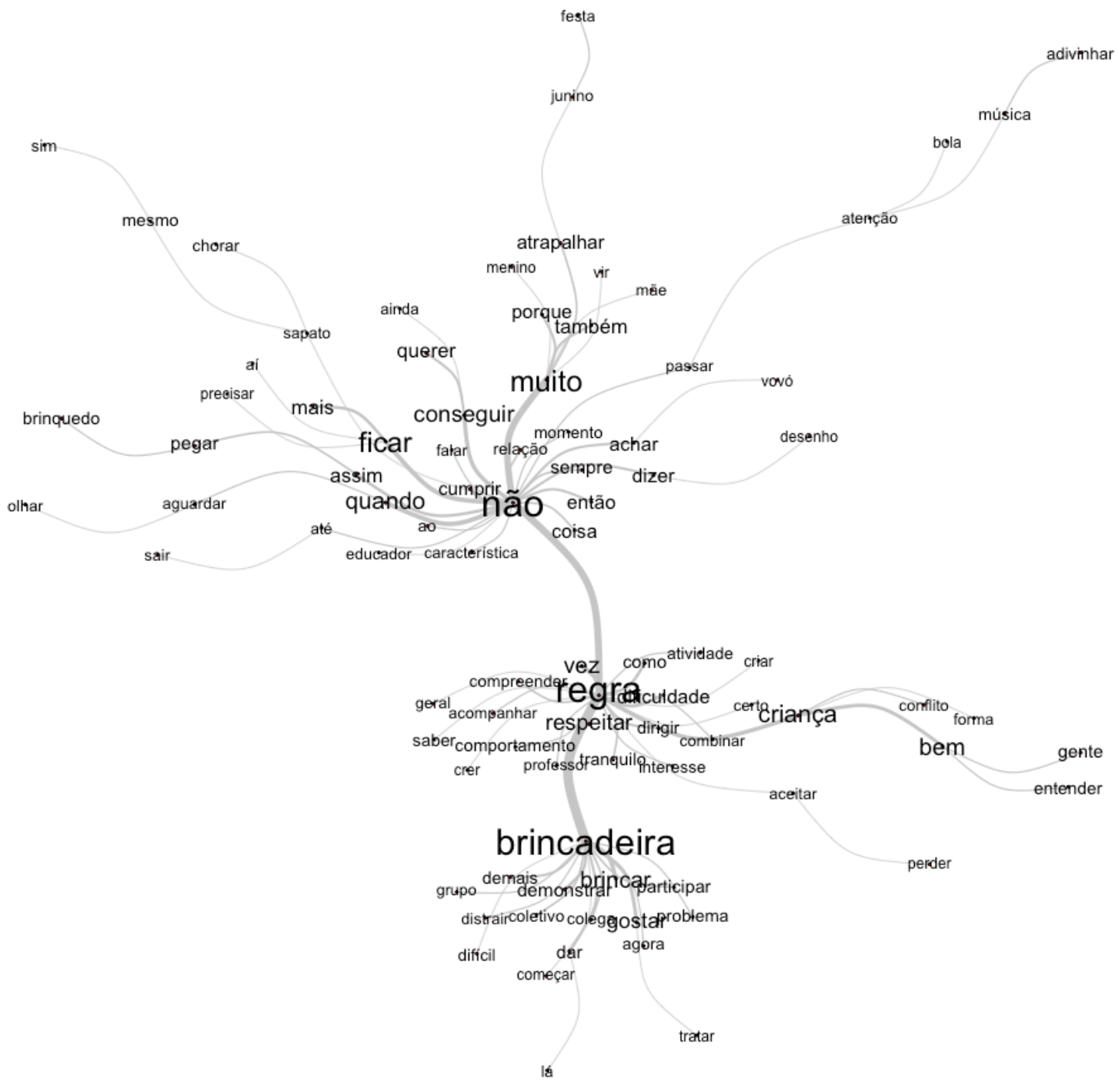

Figura 15: Árvore de palavras referente a pergunta 4 (Você conseguiria descrever, a partir das observações no dia a dia dessa criança, como é, em situações de brincadeiras em que algumas regras são estabelecidas previamente, o comportamento dessa criança, especificamente nesses momentos interativos?)

Atenta-se para o fato da referida pergunta ter podido proporcionar um discurso mais abrangente, pois exigia uma descrição dos comportamentos da criança em seus momentos de brincadeiras, com regras determinadas anteriormente. No entanto, pode-se pensar acerca das palavras que geraram três polos dentro da árvore: não, regra e brincadeira.

Pelo discurso das professoras, entende-se a palavra não como as crianças não apresentando muitas dificuldades em respeitar as regras das brincadeiras, previamente estabelecidas. Essa inferência foi possível ao compararmos os dados 
dessa pergunta com a anterior, que buscou identificar se as crianças apresentavam dificuldade em respeitar as regras gerais da turma.

Nesta questão, foi possível constatar o oposto em relação às brincadeiras com regras prévias. Esses achados são importantes para pensarmos, assim como sinalizam Vasconcellos, Seabra e Eisenberg (2012), o papel da educação infantil e a forma com que a criança se organiza interna e externamente, através da brincadeira. Neste dado, percebe-se como as regras compartilhadas em uma brincadeira ficam fáceis de serem seguidas e respeitadas, pois possivelmente, caso não as respeitem, não poderiam brincar mais e isso, normalmente, as crianças não querem.

Além disso, pode-se ainda trazer os documentos oficiais que regem a Educação, apresentados ao longo dessa pesquisa (Lei de Diretrizes e Bases da Educação Nacional $n^{\circ} 9.394$ de 26 de dezembro,1996; Base Nacional Comum Curricular, 2017; Diretrizes Curriculares Nacionais para a Educação Infantil, 2010) para lembrar que um dos principais objetivos durante a Educação Infantil é ter a brincadeira como fio condutor de todas as propostas pedagógicas. Corroborando as autoras Vasconcellos, Seabra e Eisenberg (2012) e analisando o relato das professoras nessa pergunta específica, é possível identificar essa premissa indiretamente no discurso dos participantes. 


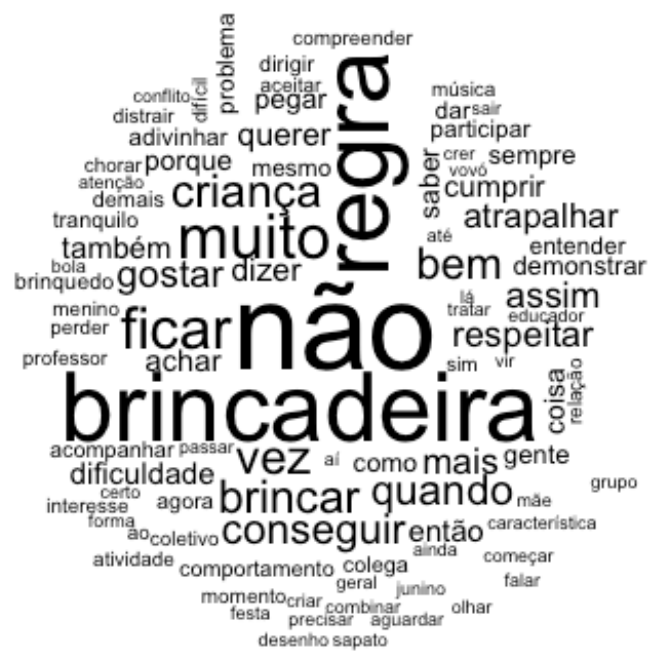

Figura 16: Nuvem de palavras referente a pergunta 4 (Pergunta 4:Você conseguiria descrever, a partir das observações no dia a dia dessa criança, como é, em situações de brincadeiras em que algumas regras são estabelecidas previamente, o comportamento dessa criança, especificamente nesses momentos interativos?)

Mais uma vez, na nuvem, percebe-se as três palavras principais já vistas na árvore das perguntas anteriores, que são: não, brincadeira e regra. Todavia, também pode-se notar outras, como: bem, brincar, conseguir, dificuldade, muito e criança. Desta forma, pode-se pensar que algumas crianças apresentam dificuldades durante a brincadeira também, mas que a maioria atende as regras e consegue, sem muitas dificuldades, cumprí-las. 


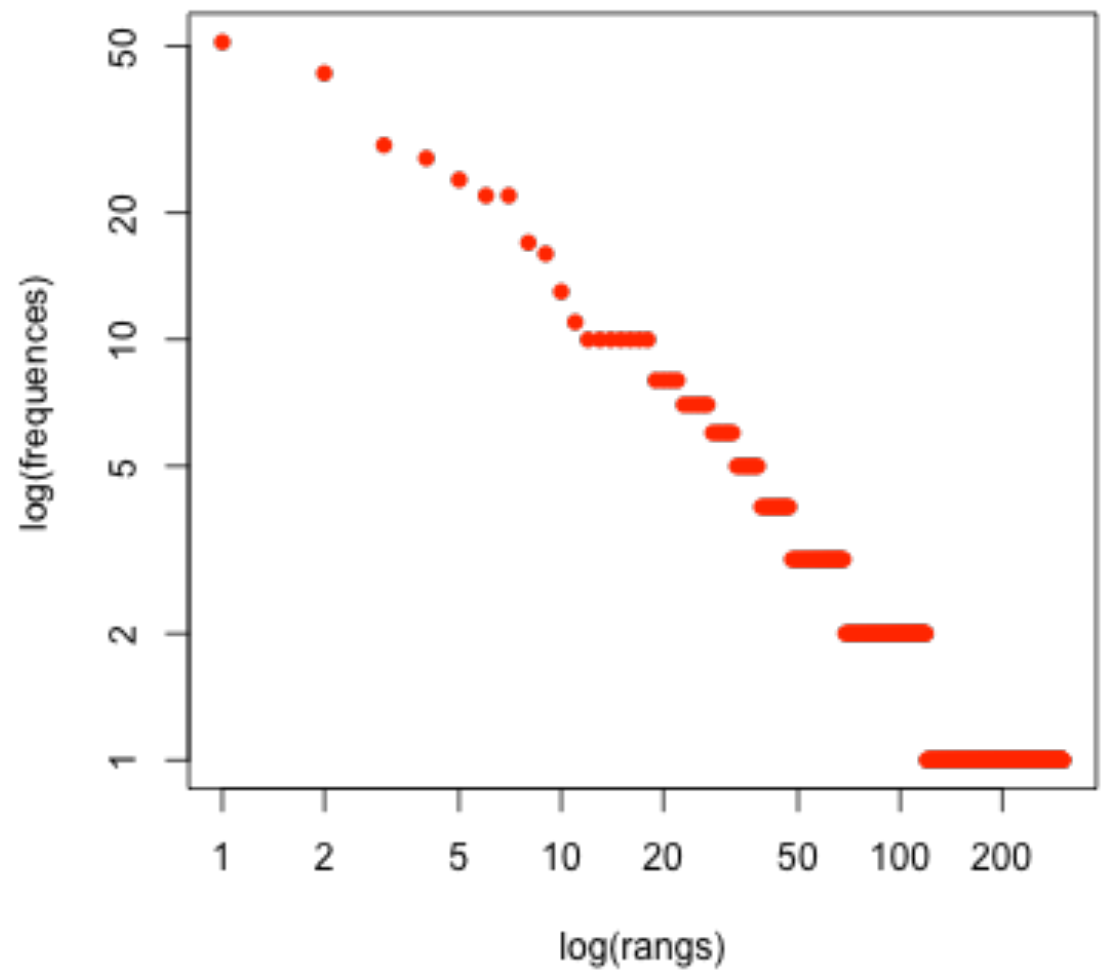

Figura 17: Frequência de palavras $X$ repetição de palavras pergunta 5 (Pergunta 5: Se você pudesse descrever o comportamento dessa criança, no seu dia a dia na escola, em cinco palavras, quais você utilizaria?)

Nesta pergunta, obtiveram-se 50 textos que representam as 50 entrevistas realizadas com 856 ocorrências de texto, isto é, o número total de palavras contidas no texto, sendo 302 formas de texto que são o número de formas presentes no texto (palavras ativas e suplementares). Além disso, 183 número de hápax, ou seja, o número de palavras que aparecem apenas uma vez em todo texto. Foram obtidos também $16,78 \%$ de média de ocorrências de palavras por texto, que representa a razão entre o número de ocorrências e o número de textos. 


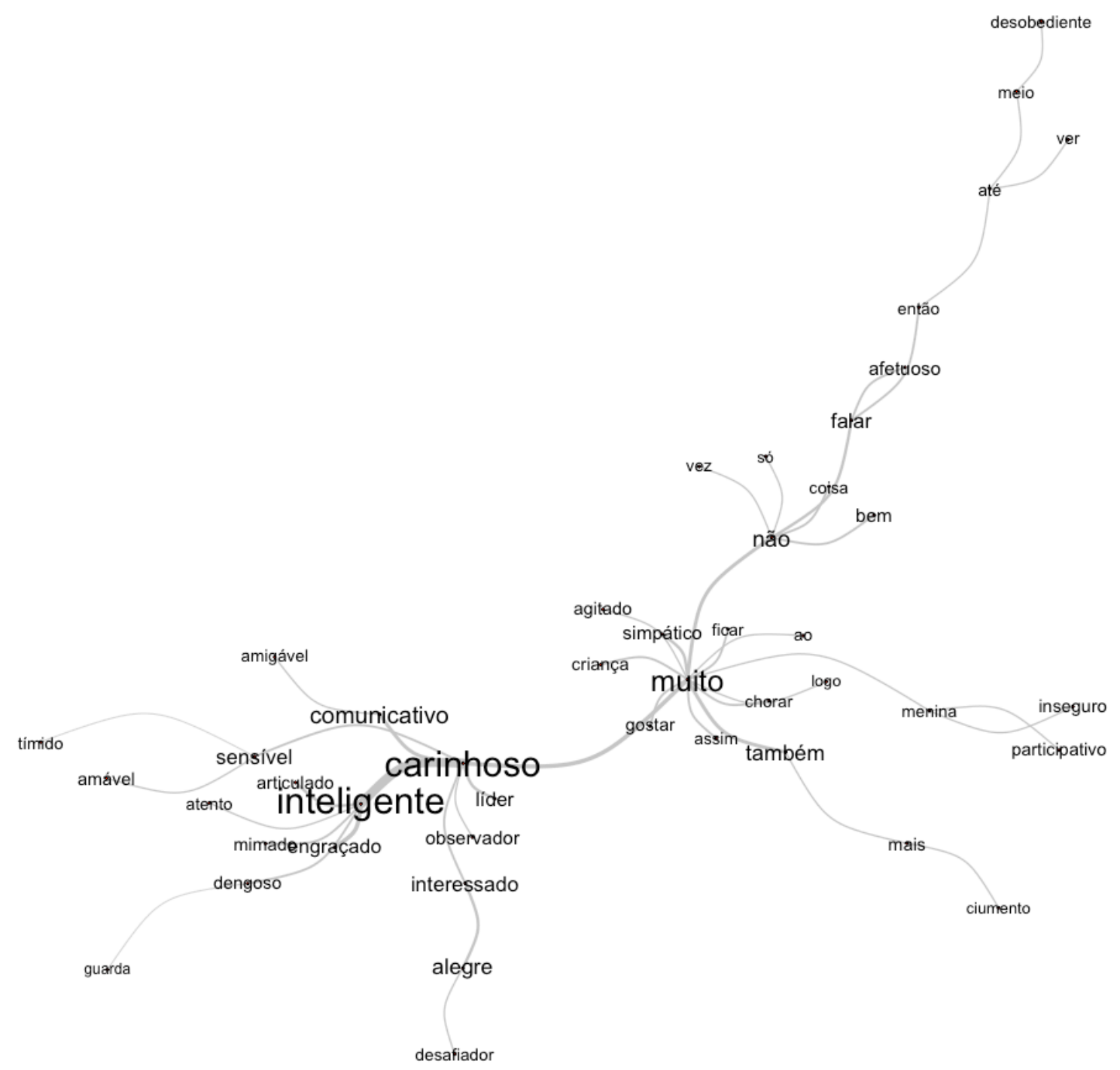

Figura 18: Árvore de palavras referente a pergunta 5 (Pergunta 5: Se você pudesse descrever o comportamento dessa criança, no seu dia a dia na escola, em cinco palavras, quais você utilizaria?)

Neste esquema, pode-se perceber que três palavras se destacam mais, são elas: inteligente, carinhoso e muito. Ou seja, para as professoras, a maioria das crianças são carinhosas e inteligentes. Desta forma, corrobora-se o dado da pergunta 1, em que poucas professoras citaram comportamentos agressivos ou transgressores nas crianças da sua turma, visto que percebem nelas afeto e carinho. 
Pode-se notar também que a maioria das professoras utiliza do superlativo para descrever o comportamento das crianças em palavras, por exemplo, muito carinhoso, muito simpático, engraçadíssimo. Percebe-se que a maioria das palavras citadas foram com um viés positivo, isto é, um olhar para as características positivas das crianças.

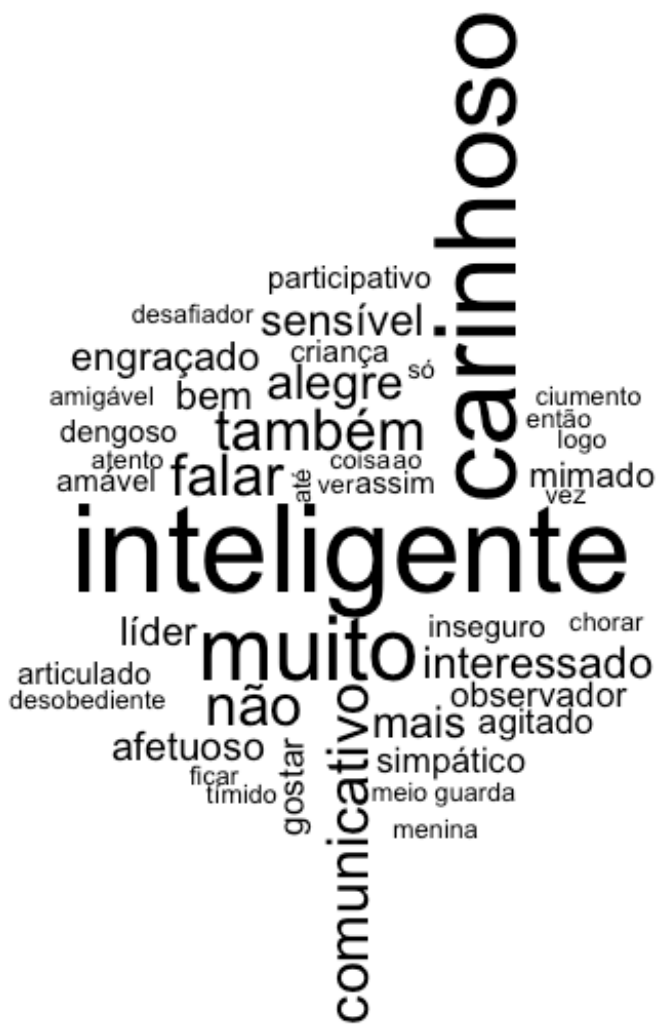

Figura 19: Nuvem de palavras referente a pergunta 5 (Pergunta 5: Se você pudesse descrever o comportamento dessa criança, no seu dia a dia na escola, em cinco palavras, quais você utilizaria?)

Nesta nuvem, consegue-se perceber mais algumas palavras em destaque, como: comunicativo, interessado, observador, sensível e engraçado. Com isso, 
pode-se corroborar o que foi analisado na pergunta 5 (Se você pudesse descrever o comportamento dessa criança, no seu dia a dia na escola, em cinco palavras, quais você utilizaria?), em que a maioria das palavras emitidas foram de cunho positivo, demonstrando que as crianças observadas nessa amostra não apresentam, em sua maioria, comportamentos agressivos ou transgressores.

Para a analise do Instrumento Escala de Crenças Parentais de Cuidado (ECPPC) na primeira infância, foi feita uma tabela com todas as respostas e os níveis mais escolhidos pelos entrevistados. $\mathrm{O}$ instrumento apresenta 25 afirmativas do tipo likert com níveis de 1 a 5 , sendo 1 nunca e 5 sempre. A maioria das afirmativas recebeu o nível 5, como resposta dos pais e mães, e apenas as afirmativas 9, 14 e 18 obtiveram o nível 1 como escolha da maioria.

$\mathrm{Na}$ afirmativa 1, a maioria dos pais e mães optou pelo nível 5 do instrumento, isto é, sempre socorrem a criança quando está chorando. Todavia, na afirmativa 14, a maioria respondeu nível 1, o que significa que nunca brincam de luta ou de se embolar com a criança.

Desta forma, pode-se dizer que a maioria dos pais e mães, que participou da pesquisa, afirma ter práticas de cuidado atentas e presentes, visto que, grande parte das respostas apontou o nível 5 (sempre). Esses achados nos remetem a Keller (2007), que descreve seis sistemas parentais, organizados de acordo com trajetórias distintas. Estes sistemas parentais envolvem um conjunto de atividades para atender às necessidades do bebê, que são: contato corporal, estimulação corporal, estimulação por objetos e cuidados básicos, face a face e envelope narrativo.

Foi possível identificar, pelos dados obtidos no presente trabalho, que houve diferentes modos de investimento parental e que o contexto ecológico, no qual o desenvolvimento se dá, pode interferir nos tipos de metas de socialização que são valorizadas e, portanto, nos sistemas de cuidados predominantes, como nos aponta Keller (2007). Nota-se que a maioria dos pais e mães não brinca de lutas ou de se embolar. Assim, pode-se supor que o ambiente da favela, com diversas experiências violentas, poderia minimizar a ocorrência dessas brincadeiras, pois a mesma poderia estar remetendo a situações de violência. 


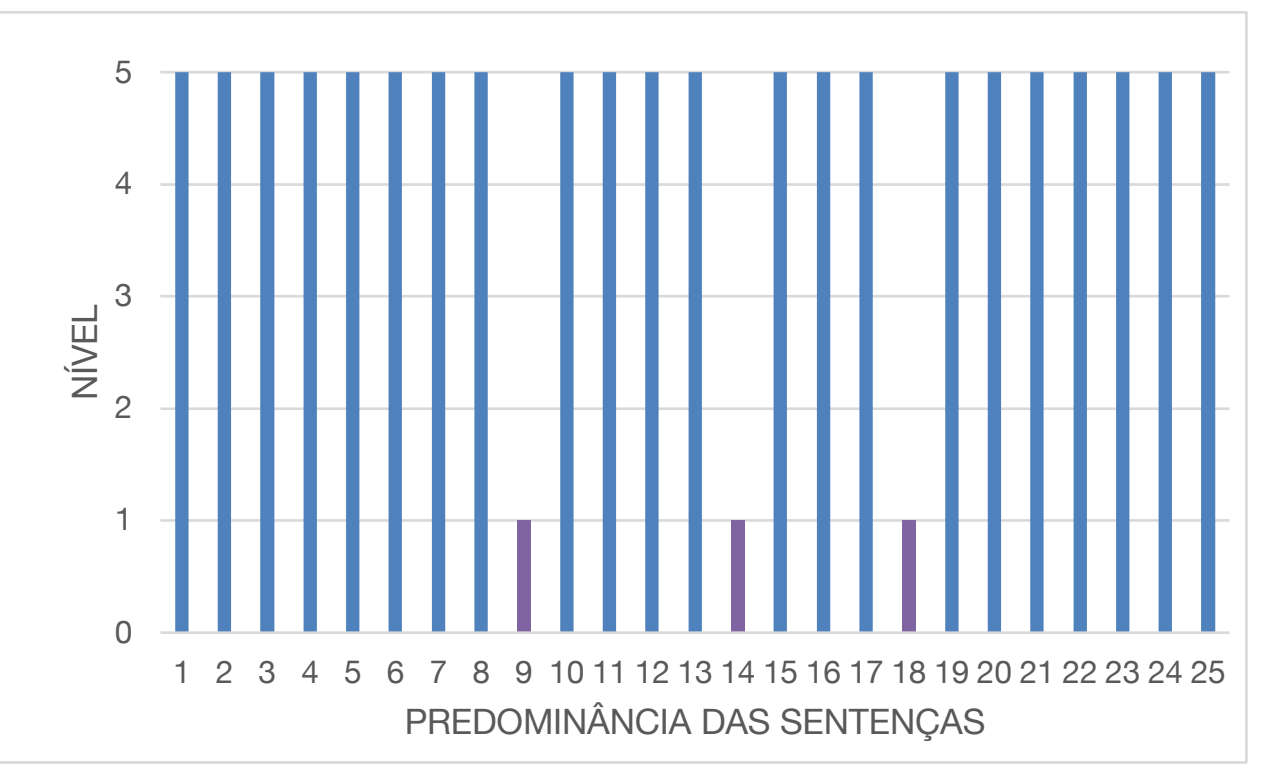

Gráfico 6: Predominância de nível $\mathrm{X}$ afirmativas da escala pelos participantes com Ensino Médio completo

Neste gráfico, encontra-se a predominância dos níveis escolhidos pelos participantes com Ensino Médio completo, visto que foi o nível de escolaridade com maior número de participantes.

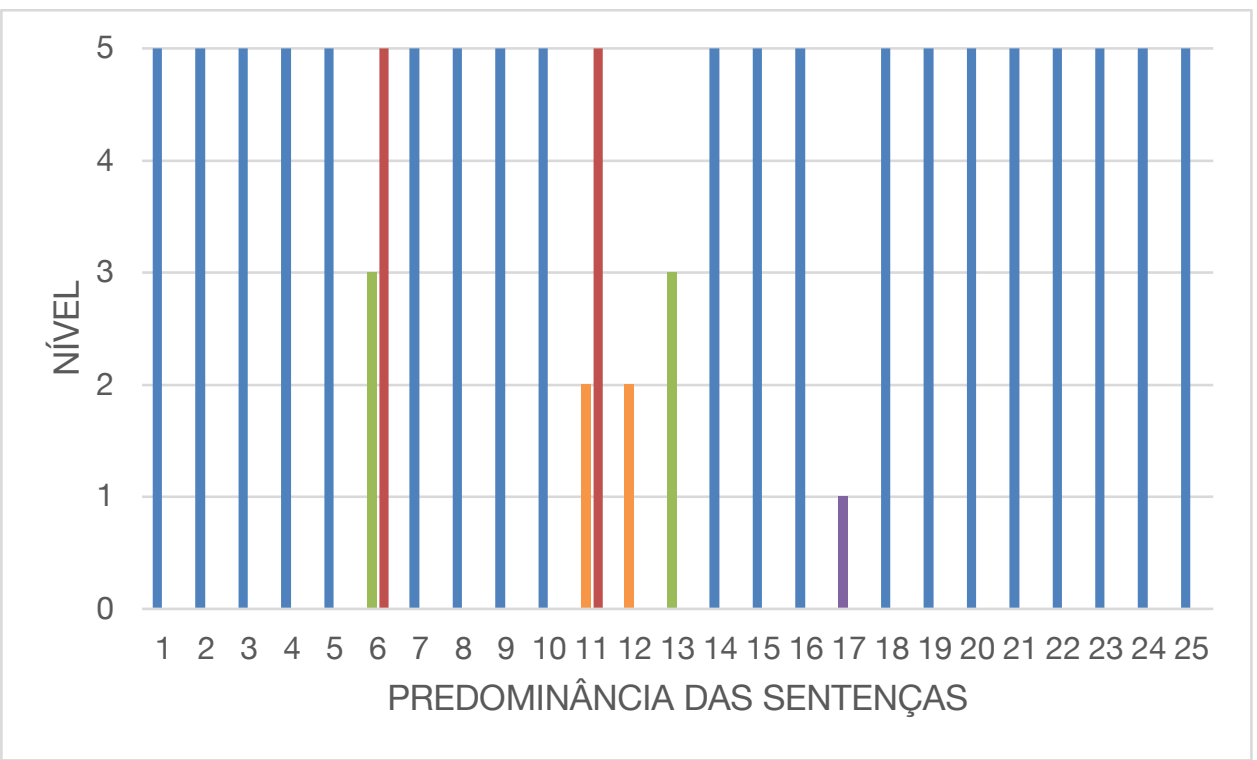

Gráfico 7: Predominância de nível $\mathrm{X}$ afirmativas da escala pelos participantes com Ensino Fundamental Incompleto

Neste gráfico, apresentam-se os dados referentes à predominância dos níveis de escala para os participantes com formação de Ensino Fundamental Incompleto, pois foi o segundo maior nível de escolaridade encontrado nesta pesquisa. Com 
isso, a partir desses dois gráficos pode-se ter uma visão da predominância de escolhas de todos os participantes.

Nota-se nesses dois gráficos que há diferenças na predominância das respostas, referente aos participantes com uma escolaridade Ensino Médio Completo e Ensino Fundamental Incompleto. Nas afirmativas 6 (carregar no colo), 9 (dormir junto na rede ou cama), 11 (fazer cócegas), 12 (fazer massagem), 13 (deixar livre para correr, nadar, trepar), 14 (brincadeiras de luta, de se embolar/corporais), 17 (jogar jogos) e 18 (pendurar brinquedos no berço), notou-se diferenças significativas nas escolhas dos participantes. Percebe-se que para os pais com escolaridade Ensino Fundamental Incompleto, a afirmativa 6 obteve dois níveis de predominância, o nível 5(sempre) e o nível 3(às vezes), enquanto que para os participantes com Ensino Médio Completo, o nível escolhido foi o 5. Desta forma, pode-se pensar que para os participantes com nível de escolaridade mais baixo, a questão do colo não ocorre sempre, possibilitando a interpretação de que a criança de 4 a 5 anos pode ter autonomia para andar e se locomover.

Porém, na afirmativa 9, os participantes com Ensino Fundamental Incompleto dormem sempre juntos com seus filhos, enquanto os participantes com Ensino Médio Completo relatam nunca fazerem isso. Neste momento, percebe-se uma inversão em relação a questão da autonomia, visto que as crianças de 4 a 5 anos podem dormir sozinhas, mas precisam de colo para o segundo grupo de participantes citado acima. Todavia, para o outro grupo, as crianças não precisam de colo, mas sempre dormem juntas aos pais.

$\mathrm{Na}$ afirmativa 11 percebe-se, mais uma vez, a escolha de dois níveis pelos participantes com Ensino Fundamental Incompleto. Os mesmos escolheram nível 2 e nível 5 para a afirmativa sobre as cócegas. Nota-se, assim, que, mais uma vez, há um grupo desses participantes que raramente exercem esse ato de contato com seus filhos. Enquanto que para o grupo com Ensino Médio Completo, essa ação ocorre sempre junto às crianças.

Para a afirmativa 12, os participantes com escolaridade Ensino Fundamental Incompleto relatam raramente fazer massagem em seus filhos, enquanto os participantes com Ensino Médio Completo exercem essa ação sempre. Ou seja, novamente, depara-se com uma afirmativa que traz a questão do contato físico e que o primeiro grupo relata exercer raramente. 
Nas afirmativas 14, 17 e 18 obtiveram-se respostas inversas, isto é, enquanto o grupo com escolaridade Ensino Fundamental Incompleto escolheu o nível 5 para as afirmativas 14 e 18, o grupo com Ensino Médio Completo escolheu o nível 1. Além disso, na afirmativa 17, enquanto o grupo de menor escolaridade escolheu o nível 1, o grupo com escolaridade superior a ele escolheu o nível 5. Logo, para o grupo com Ensino Fundamental Incompleto não há qualquer questão com as brincadeiras de lutas, de se embolar; para o grupo com Ensino Médio Completo esse tipo de brincadeira não ocorre nunca. Ou seja, nesse caso há o contato corporal pelo primeiro grupo citado que não estava aparecendo nas afirmativas anteriores.

Com relação aos jogos, percebe-se que não é comum esse tipo de escolha para brincar com as crianças pelo grupo com escolaridade Ensino Fundamental Incompleto. No entanto, é uma escolha que sempre ocorre para os pais com Ensino Médio Completo.

Por último, a afirmativa 18, sobre pendurar brinquedos no berço, nota-se que as crianças com os pais de escolaridade Ensino Fundamental Incompleto permanecem com os berços em casa. Já os pais com Ensino Médio Completo demonstram, pela escolha do nível 1, que as crianças não devem mais ter acesso ao berço.

A partir dessas análises, pode-se responder ao primeiro objetivo específico proposto nessa pesquisa. Nota-se que a maioria dos pais e mães demonstra em suas respostas preocupações e cuidados com seus filhos, visto que para a maioria das afirmativas eles responderam nível 5 (sempre). Esse achado pode ser relacionado com as análises das entrevistas das professoras, que demonstram, de forma geral, que as crianças não apresentam comportamentos agressivos ou transgressores. Desta forma, corrobora os dados apresentados nas análises do E-CPPC, em que os pais e mães demonstram preocupações com os cuidados, como já mencionado anteriormente, e consequentemente isso pode ser correlacionado positivamente com o discurso das professoras que relataram que as crianças não apresentavam comportamentos agressivos ou transgressores na escola.

A partir dessas análises, também pode-se responder ao segundo objetivo específico proposto desta tese. Com esses resultados apresentados nos gráficos, conseguiu-se investigar a possível relação entre as práticas educativas parentais e as características sociodemográficas dos pais.

Logo, como nos diz Bronfenbrenner (1992), pode-se verificar as possíveis influências na relação da criança com o ambiente onde está inserida. Acredita-se 
que, se a criança está inserida em um ambiente saudável para seu desenvolvimento, ela dificilmente apresentará comportamentos transgressores ou agressivos nesses espaços. A partir das análises das respostas dos pais e das professoras, pode-se dizer que os aspectos relacionados a crenças e práticas parentais estão de acordo com o perfil de comportamento apontado pelas professoras em suas entrevistas.

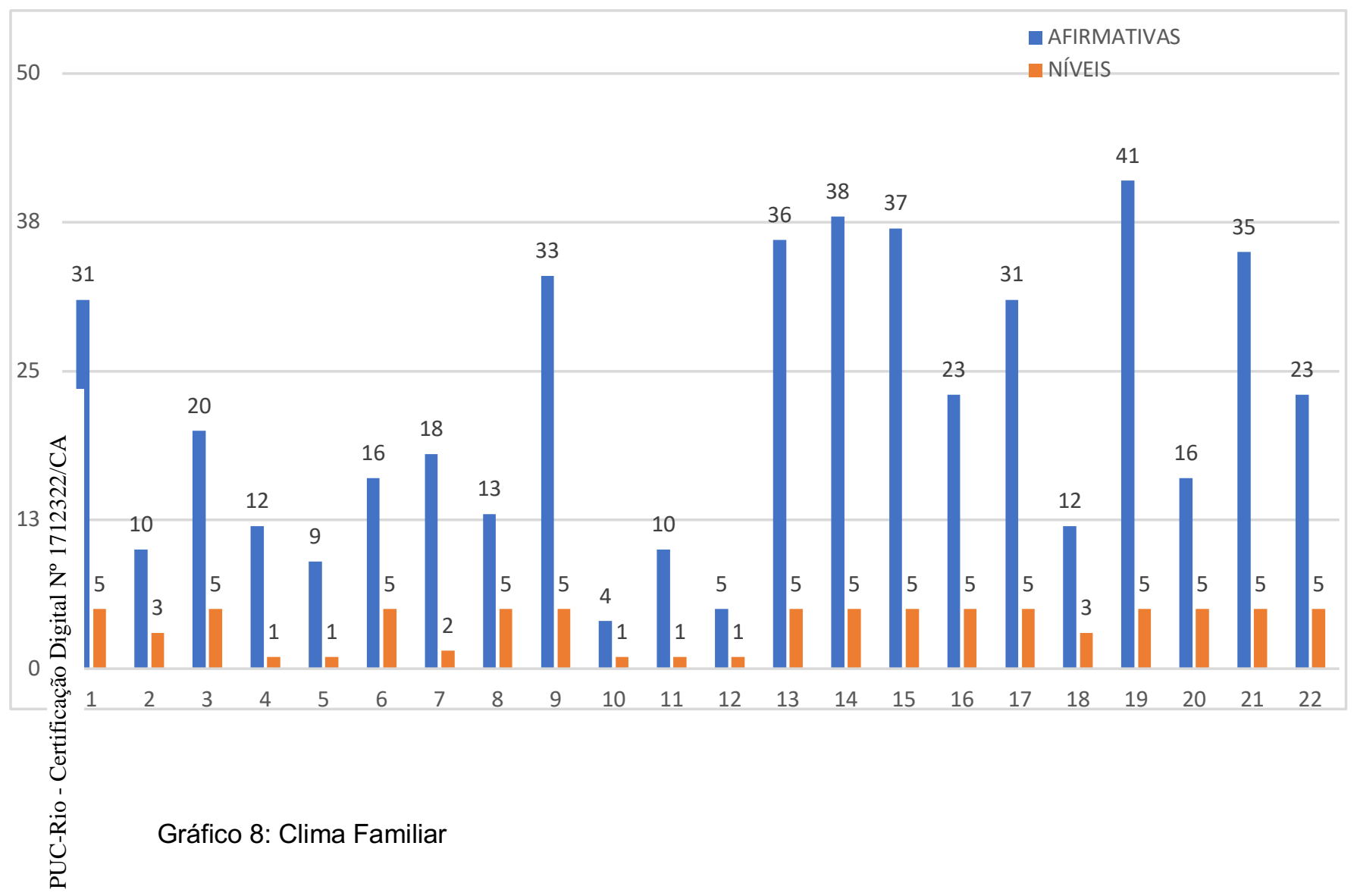

A análise do clima familiar possibilitou dados interessantes que ajudam a responder o terceiro objetivo especifico dessa pesquisa. No instrumento Inventário de Clima Familiar, nota-se que as respostas não foram tão parecidas quanto no instrumento E-CPPC. Ainda assim, a maioria dos pais e mães respondeu o nível 5 (concordo completamente) em grande parte das afirmativas do instrumento. No entanto, algumas afirmativas chamam atenção.

Por exemplo, têm-se as afirmativas 2 (as proibições são constantes) com nível 3 (mais ou menos) de escolha da maioria. Há a afirmativa 3 (uns mandam e outros obedecem) com nível 5 (concordo completamente) de maior escolha pelos participantes. Na afirmativa 18 (os filhos têm pouco poder nas decisões familiares), 
a maioria assinalou o nível 3 (mais ou menos). Além disso, na afirmativa 20 (algumas pessoas resolvem os problemas de maneira autoritária), obteve-se a escolha da maioria nível 5 (concordo completamente). Faz-se importante ressaltar, também, que na sétima afirmativa (não importa a vontade da maioria, a decisão final é sempre da mesma pessoa), houve um empate no número de respostas, pois a maioria marcou nível 1 (de jeito nenhum) e nível 5 (concordo completamente). Tais afirmações foram selecionadas, pois há nelas importantes análises a serem apresentadas.

Pode-se pensar que, para a maioria dessas famílias, a forma de educar em casa é através do autoritarismo, com muitas proibições, sem que a opinião dos filhos seja considerada. Parece que a aprendizagem ocorre na dinâmica em que algumas pessoas mandam e outras obedecem. Na rotina da Educação Infantil, tem-se como base o desenvolvimento da autonomia da criança durante o processo da criação das regras e combinados da sala. Supõe-se que as crianças tenham vez e voz durante esse processo (Vasconcellos, Seabra \& Eisenberg, 2012).

Quando uma criança aprende que ela não tem direito a escolhas frente às diferentes decisões da família, ela passa a realizar as tarefas que são mandadas pelos adultos. Com isso, não é necessário que essa criança pense sobre a ação que está sendo realizada ou o seu porquê.

Com isso, quando essa criança encontra-se no ambiente da escola, onde ela pode ter autonomia nas suas escolhas, na organização dos combinados e regras daquele espaço coletivo, ela pode apresentar dificuldades durante esse processo. Isso acontece, pois, no ambiente de casa, como representam os dados, a criança não encontra essa realidade, mas sim a realidade de ser mandada por alguém o tempo todo.

Todavia, esse tipo de dificuldade não é tão encontrado durante as brincadeiras com regras pré-determinadas. Por exemplo: pique-esconde, pique-pega, dentre outras. Desta forma, pode-se pensar em estratégias através de brincadeiras para auxiliar nesse processo de entendimento das regras para as crianças dessa faixa etária.

Bronfenbrenner (1977) destaca a possibilidade de que eventos em um ambiente podem influenciar o comportamento da criança e seu processo de desenvolvimento. Assim, a experiência de uma criança na creche, na sala de aula, ou no grupo de pares informal pode mudar seu padrão de atividades e interação com pais ou irmãos em casa, ou vice-versa, com as consequentes implicações para a aprendizagem e o desenvolvimento. Desta forma, é compreensível esses comportamentos 
encontrados nos resultados da pesquisa. Além disso, quando Bronfenbrenner (1977) apresenta a questão do espaço, pode-se pensar nos hábitos dessa família em casa com a criança. Sendo assim, mais uma vez, destacam-se os resultados acerca das proibições e do autoritarismo presente na maioria das famílias pesquisadas e o quanto está relacionado ao comportamento da criança na creche ou em casa.

Apesar dessas questões referentes ao autoritarismo, as constantes proibições e o pouco poder de decisão dos filhos, quando o instrumento apresentou afirmativas sobre o relacionamento interpessoal familiar, a maioria dos participantes respondeu concordar completamente, por exemplo com: as pessoas tentam ajudar umas às outras quando as coisas não vão bem, as pessoas gostam umas das outras, sinto que existe união entre os membros e temos prazer e alegria em passar o tempo juntos. Logo, mais uma vez, foi possível perceber que, na maioria das famílias, existe também um clima amigável, afetuoso e amoroso. Justificam-se, assim, as características encontradas nas crianças e as poucas falas das professoras referentes ao comportamento transgressor ou agressivo delas.

Pode-se pensar, assim como a afirmação de Del Prette e Del Prette (2010), que a infância é um período crítico para a aprendizagem de habilidades sociais e as normas de convivência, e que estas ocorrem primeiramente com a família e em seguida em outros ambientes, como por exemplo, a creche e a pré-escola.

Além de Del Prette e Del Prette (2010), lembra-se da importância que Bronfenbrener (1999) traz sobre a compreensão dos diferentes contextos que fazem parte da vida das crianças, pois para ele não há inseparabilidade entre o organismo e o meio em que se vive. Com isso, reforça-se o quanto faz-se necessário os estudos acerca desses meios ou contextos nos quais a criança está inserida, como, por exemplo, o espaço escolar e o meio familiar. Assim, objetiva-se ter maior conhecimento acerca do desenvolvimento dessa criança.

Bronfenbrenner (1999) considera que as diferentes formas de interação das pessoas não são apenas em função do ambiente. Elas são resultantes de processos, ou seja, das relações entre o ambiente e as características da pessoa. Por isso, vale lembrar dos quatro núcleos interrelacionados do processo que engloba as experiências vividas, as interpretações e os significados internalizados pelas pessoas, entre elas com/em o ambiente.

A partir dos resultados obtidos nesta pesquisa e lembrando os núcleos apresentados por Bronfenbrenner (1999), a pessoa, que é um desses núcleos, apresenta 
características determinadas biopsicologicamente e construídas através da interação com o ambiente. Esta apresenta disfunção e competência. A disfunção é uma dificuldade em manter o controle e a integração de comportamento, e a competência é a aquisição de conhecimentos, habilidades e capacidades para produzir e dirigir o comportamento. Ambas têm fundamental influência na direção e no conteúdo dos processos proximais. Logo, percebe-se, nesta pesquisa, que a partir do relato das professoras, as crianças estão apresentando maiores competências do que a disfunção em relação ao seu comportamento na escola.

Além disso, a interação dos quatro níveis ambientais trazidos por Bronfenbrenner (1999) mostra o quanto as crianças circulam e interagem com eles. Sendo assim, quanto maior for a clareza entre a escola e a família, que representam dois microssistemas, melhor torna-se o desenvolvimento destas crianças. Nesta pesquisa, por exemplo, pode-se perceber uma boa interação entre as famílias e as escolas pesquisadas, visto que os resultados apresentados foram coerentes e complementares acerca das informaçãoes prestadas.

Porém, não pode-se deixar de destacar que as relações que se estabelecem entre as mães e os educadores podem variar muito, dependendo de vários fatores, dentre eles, a qualidade do atendimento da creche e o nível de participação que esta oferece às famílias. Estes dois pontos, evidentemente, apoiam-se em concepções sobre o papel da creche e da família (Oliveira, Mello, Vitória e Ferreira, 2009). Logo, possivelmente nas escolas participantes da pesquisa, esses fatores mostramse positivos.

Lembra-se também, a partir do nicho de desenvolvimento apresentado por Harkness e Super (1994), onde a família é o centro da vida humana inicial, que o desenvolvimento da criança tem uma relação dinâmica com o ambiente físico e social, além da relação com as práticas de cuidados infantis, culturalmente reguladas, e com a psicologia de cuidadores. Ou seja, isso demonstra a extrema importância da escola para criar vínculos com esses pais ou cuidadores principais. Por isso, manter esse canal de participação aberto junto à família no espaço da creche é fundamental para o desenvolvimento saudável e integral da criança.

Desta forma, conclui-se que todos os objetivos propostos na pesquisa foram alcançados. Além disso, observa-se o quanto as teorias de Bronfenbrenner (1992) e Harkness e Super (1986), relacionadas à influência do ambiente no desenvolvimento das crianças, puderam ser, mais uma vez, corroboradas neste estudo. 
Percebe-se o quanto os comportamentos transgressores ou agressivos não se fizeram presentes, diretamente nesta pesquisa, na fala das professoras. O que pode ser observado a partir dos dados obtidos com os pais ou mães participantes, em que muitos mostram a valorização da proximidade familiar, o suporte, caso um membro da família esteja precisando de ajuda, o afeto e carinho presentes entre os seus membros, o prazer em estarem juntos e a união presente na família.

Tal fato corrobora os pressupostos de Lansford et al. (2011) e Patterson e Yoerger (2002), ao afirmarem a relação entre o suporte emocional familiar e as práticas educativas parentais. Estas, quando têm foco na disciplina física punitiva, contribuem para a manifestação de comportamentos agressivos na infância.

Não se pode afirmar que tais disciplinas físicas punitivas não existam nas famílias pesquisadas, porém, pode-se pensar que mesmo que existam, outras práticas educativas dão suporte emocional a essas crianças, em vista dos comportamentos descritos pelas professoras.

Logo, os resultados apresentados, específicos dos participantes dessa pesquisa, apesar de ser um recorte, estão em consonância com as hipóteses apresentadas inicialmente no presente trabalho. 


\section{Considerações finais:}

O presente trabalho conseguiu atingir seus objetivos de investigar as relações das práticas educativas parentais e as características familiares, e sua relação com os comportamentos transgressores das crianças de 3 à 5 anos no ambiente escolar. Este trabalho foi realizado em duas Unidades Escolares, uma creche e um Espaço de Desenvolvimento Infantil (EDI), na $2^{\text {a }}$ Coordenadoria Regional de Educação (CRE) pública do município do Rio de Janeiro.

Conseguiu-se comparar as práticas educativas parentais e o perfil comportamental transgressor das crianças da faixa etária citada acima, a partir dos relatos das professoras. Realizou-se, também, a investigação da relação entre as práticas educativas parentais e as características sociodemográficas dos pais. Além de comparar os níveis de Clima Familiar e o comportamento das crianças de 3 à 5 anos relatados, também, pelas professoras. Desta forma, conseguiu-se identificar a relação entre a vivência das crianças no contexto do ambiente familiar e da escola. Visto que, como mostram os dados, a maioria das famílias participantes relataram um ambiente familiar afetuoso e durante a fala das professoras percebe-se esse afeto no comportamento das crianças no ambiente escolar.

Como mostram os estudos de Bronfenbrenner (2011), Harkness e Super (2009), um dos pressupostos deste trabalho é que o desenvolvimento humano se dá em contextos. Desta forma, acredita-se que, durante a Educação Infantil, para se compreender o desenvolvimento, faz-se necessário a investigação dos diferentes contextos que permeam a vida das crianças.

Destacou-se a relevância das características sociodemográficas, em especial o nível de escolaridade, pois a maioria dos participantes tinham o Ensino Médio Completo (42\%), seguido do Ensino Fundamental Incompleto (24\%), predominantemente. Ou seja, nota-se que, nesse grupo pesquisado, poucos pais tiveram acesso ao nível superior de ensino (4\%). Sabe-se o quanto a educação superior, no Brasil, é escassa para as pessoas que vivem à margem da sociedade, como por exemplo nas favelas, onde estava alocada uma das Unidades Escolares pesquisadas. Logo, encontram-se nessa pesquisas pais e mães que moram em favelas da zona norte e zona sul do Rio de Janeiro que muitas vezes não são vistos nas pesquisas acadêmicas. 
Notou-se, a partir do relato das professoras, que nestes dois espaços pesquisados, as crianças, em sua maioria, não apresentam aspectos transgressores. Foi possível ainda perceber que a maioria das famílias se preocupa com as práticas de cuidados e acredita na importância desses cuidados para o desenvolvimento dos filhos. Além disso, no Clima Familiar, a maioria também demonstrou viver em ambientes afetuosos e amorosos com seus familiares, tendo apenas alguns pontos relacionados ao respeito, escuta à fala do filho(a) e o autoritarismo presentes na educação dos mesmos, o que dá margem para se entender alguns comportamentos citados pelas professoras, tais como: a dificuldade de cumprir os combinados da turma, mas quando são regras das brincadeiras não tinham qualquer dificuldades. Além das muitas citações com relação ao carinho e afeto das crianças entre elas e com as professoras.

Durante os relatos das professoras notou-se uma preocupação em realçarem os aspectos positivos das crianças, não que essas crianças não apresentassem comportamentos transgressores, todavia, o que era mais enfatizado pelas professoras eram os comportamentos positivos. Logo, o fato de não ter aparecido, nos relatos, tais comportamentos, não quer dizer que não existam. Os participantes optaram por privilegiar a apresentação de outros comportamentos.

Conclui-se, assim, que os dados encontrados poderão gerar diversas discussões acerca do tema, isto é, colocar a questão dos comportamentos transgressores em pauta de reuniões pedagógicas, realizar grupos de estudos acerca desta temática, principalmente da relação dela com as questões famíliares presentes nas Unidades Escolares. Muitas professoras, por exemplo, relataram a importância da observação, dos aspectos presentes na entrevista feita à elas referentes ao comportamento transgressor da criança, durante o período da creche ou pré-escola, em diferentes momentos do dia.

Além disso, os profissionais da Unidade Escolar se interessaram pelos instrumentos Escala de Crenças Parentais de Cuidado (E-CPPC) e Clima Familiar, preenchidos pelos pais. Eles relataram que esses instrumentos poderiam auxiliar a creche ou a pré-escola à entender melhor as situações que as famílias da Unidade Escolar vivem e acreditam sobre a educação dos filhos. Com isso, solicitaram tais instrumentos ao final da pesquisa, caso fosse possível.

Esse estudo apresentou limitações, tais como, ter um número reduzido de participantes de outras Unidades Escolares de Educação Infantil públicas da 2a Cre 
do município do Rio de Janeiro, contou com apenas três instrumentos, não foi possível realizar um estudo de observação nos espaços escolares e o número reduzido de participantes totais. Contudo, acredita-se que com os dados obtidos, muitos pesquisadores e profissionais da área de educação e psicologia, que se intesessarem pelo tema família, Educação Infantil e comportamentos transgressores, podem perceber a relevância dessas duas áreas dialogarem e se articularem na tentativa de buscar um denominador comum que é o desenvolvimento integral da criança.

Cabe ressaltar que a originalidade desta tese reside na proposta de investigar uma amostra de diferentes configurações familiares, principalmente as das categorias declaradas como de baixa renda do município do Rio de Janeiro.

Tal estudo poderá contribuir para o desenvolvimento de novas pesquisas no campo de educação infantil, principalmente, na rede pública de ensino e em Unidades Escolares próximas ou dentro de favelas no Rio de Janeiro, além da rede particular. Nota-se, ainda, a pouca visibilidade desse grupamento nos estudos com a temática das famílias, tanto na área de psicologia quanto na área de educação.

Acredita-se que, a partir dos achados da presente tese, as escolas e os professores poderão perceber a importância de conhecer as práticas de cuidado e crenças dos diferentes cuidadores da sua Unidade Escolar, além do contexto e da dimâmica familiar em que cada criança está inserida. Dessa forma, entender e conhecer mais acerca das crianças e seus familiares. Assim, reforça-se a importância da troca e do diálogo referentes aos cuidados da criança entre a família e os profissionais da escola para um melhor desenvolvimento da criança nesse processo, visando sempre o bem-estar e a promoção de saúde da criança.

A partir da Teoria Bioecológica de Bronfenbrenner (1999), pode-se dizer que o mesossistema escola-família precisa ser e estar bem articulado para que o desenvolvimento da criança possa acontecer de forma qualitativamente saudável. Uma possibilidade para que isso ocorra é o planejamento de reuniões, encontros e espaços onde tanto a família quanto os profissionais da escola possam se expressar em relação a educação das crianças.

Logo, espera-se que esta pesquisa possa ser referência para novas investigações acerca do tema, em novos espaços e com diversos participantes. Além disso, que possa haver uma investigação em que as crianças também sejam ouvidas e observadas pelos pesquisadores da área. É um desafio, ainda, realizarmos pesquisas 
com as crianças dos espaços escolares públicos e privados, assim como muitos outros desafios que encontramos ao realizar pesquisa no Brasil. Porém, acredita-se que é fundamental a realização de pesquisas com a participação infantil nos trabalhos científicos. 


\section{9- Referências bibliográficas:}

Almeida, F. M. C. (2013). Família e educadores da infância: um diálogo possível. [Tese]. Faculdade de Educação, Universidade do Estado do Rio de Janeiro, Rio de Janeiro. Almeida, F. M. C. \& Vasconcellos, V. M. R. (2009). Comunicação Levantamento bibliográfico de estudos brasileiros sobre mãe-bebê, família e creche.

Almeida, L. S. De \& Vasconcellos, V. M. R. (2018). Famílias Cariocas e os cuidados infantis. In L. F. Pessôa, D. M. L. F. Mendes \& M. L. Seidl-de-Moura (Orgs.), Parentalidade: Diferentes perspectivas, evidências e experiências. (1. ed. , 207p.) Curitiba: Appris.

Bandeira, T. T. A.; Moura M. L. S.; Vieira M. L. (2009). Metas de socialização de pais e mães para seus filhos. Revista - Brasileira de Crescimento Desenvolvimento Humano, 19(3), 445-456.

Rっhia, C. C. S.; Magalhães, C. M. C.; Pontes, FAR (2008). A relação creche-família na visão de professoras e mães usuárias de creche. [Tese]. Faculdade de Psicologia, Universidade do Pará.

hia, C. C. S.; Magalhães, C. M. C.; Pontes, F. A. R. (2011). Crenças de mães e professoras sobre o desenvolvimento da criança. Fractal: Revista de Psicologia, 23(1), 99-122.

zker, S. M. S. \& Martins, G. D. (2013). Práticas e crenças de educadoras de berçário sobre cuidado.Psicologia em Estudo,18(3), 551-560.

ndioli, A. (1998). A dimensão lúdica na criança de 0 a 3 anos na creche.

In: Bondioli, A. \& Mantovani, S. Manual de educação infantil: de 0 a 3 anos. Porto Alegre: Artes Médicas, 9a edição, p.212-227.

Bhering, E; Siraj-Blatchford, I. (2009). A relação escola-pais: um modelo de trocas e colaboração. Cadernos de Pesquisa, 106, 191-206.

Bolsoni-Silva, A. T., Marturano, E. M., \& Manfrinato, J. W. De S. (2005).

Mães avaliam comportamentos socialmente "desejados" e "indesejados"de pré-escolares. Psicologia em Estudo, 10(2), 245-252.

Borsa, J. C.; Bandeira, D. R. (Orgs.) (2014). Comportamento agressivo na infância: da teoria à prática. (1 ed., 544p.) São Paulo: Person Clinical Brasil.

Bushman, B. J., \& Huesmann, L. R. (2010). Agression. In S. T. Fiske, D. T. Gilbert \& G. Lindzey (Eds.), Handbook of social psychology (5th ed., pp. 833-863). New York: John Wiley \& Sons. 
Brasil (1996). Lei de Diretrizes e Bases da Educação Nacional nº 9.394 de 26 de dezembro.

Brasil (2017). Ministério da Educação. Conselho Nacional de Educação. Câmara de Educação Básica. Base Nacional Comum Curricular. http://basenacionalcomum.mec.gov.br (acessado em 13/02/2019).

Bronfenbrenner, U. (2011). Bioecologia do desenvolvimento humano: tornando seres humanos mais humanos. Porto Alegre, Artmed.

Bronfenbrenner, U. (1999). Environments in developmental perspective: Theoretical and operational models. In B. L. Friedmann\& T. D. Wachs (Orgs.), Conceptualization and assessment of environment across the life span (pp. 3-30). Washington, DC: American Psychological Association.

Bronfenbrenner, U., \& Moris, P. A. (1998). The ecology of developmental processes.

In W. Damon \& R. M. Lerner (Orgs.), Handbook of chil psychology: Theoretical models of human development (Vol. 1, pp. 993-1027). New York: John Wiley.

ronfenbrenner, U. (1996). A ecologia do desenvolvimento humano: Experimentos naturais e planejados. Porto Alegre: Artmed.

ronfenbrenner, U. (1992). Ecological system theory. In R. Vasta (Org.). Six theories of child development: Revised formulations and current issues (pp. 187 -249).

London: Jessica Knigsley.

ronfenbrenner, U. (1986). Ecology of Family as a Context for Human Development: Research Perspectives. Developmental Psychology, 22(6),723-742.

ronfenbrenner, U. (1977). Toward an experimental ecology of Human Development. American Psychologist. Cornell University.

Camargo, B. V. \& Justo, A. M. (2013).IRAMUTEQ: um software gratuito para análisede dados textuais. Temas em Psicologia, 21(2), 2-16.

Carnagey, N. L., Anderson, C. A., \& Bushman, B. J. (2007). The effect of video game violence on physiological desensitization to real-life violence. Journal of Experimental Social Psychology, 43, 489-496

De Antoni, C. \& Koller, S.H. (2010). Uma família fisicamente violenta: uma visão pela teoria bioecológica do desenvolvimento humano. Temas em Psicologia, 18(1), 1730.

De Antoni, C. (2012). Abuso Emocional Parental contra Crianças e Adolescentes. In L. F. Habigzang \& S. H. Koller. (Orgs.), Violência contra crianças e adolescentes: teoria, pesquisa e prática. (pp. 43-54). Porto Alegre: Artmed. 
De Antoni, C., Barone, L., \& Koller, S. H. (2012). Perfil da violência em famílias com históra de abuso físico. In L. F. Habigzang \& S. H. Koller (Orgs.), Violência contra crianças e adolescentes: teoria, pesquisa e prática. (pp. 43-54). Porto Alegre: Artmed.

De Antoni, C., Barone, L., \& Koller, S. H. (2007). Indicadores de risco e de proteção em famílias fisicamente abusivas. Psicologia: Teoria e Pesquisa, 23 (2), 125-132.

De Antoni, C., \& Koller, S. H. (2017). A manifestação da agressividade na compreensão da

teoria bioecológica do desenvolvimento humano. In. J. C. Borsa \& D. R. Bandeira (Orgs.), Comportamento agressivo na infância: da teoria à prática. (pp.79-90). São Paulo: Pearson Clinical Brasil.

Del Prette, Z. A. P., \& Del Prette, A. (2010). Habilidades sociais e análise do comportamento:

proximidade histórica e atualidades. Perspectivas em Análise do Comportamento, $1(2), 104-115$.

Dessen, M. A., \& Costa Jr., Á. L. (2005). (Orgs.). A ciência do desenvolvimento humano. Tendências atuais e perspectivas futuras. Porto Alegre, RS: Armed. 278p.. De Vitta, F. C. F. \& Emmel, M. L. G. (2004). A dualidade cuidado x educação no cotidiano do berçário. Paidéia: Cadernos de Psicologia e Educação, 14, 177-189.

'omingues, K. G., Almeida, I. M. Z. P. de, \& Cerqueira, T. C. S. (2013). Transgressão e criatividade em sala de aula. Estilos da Clinica, 18(2), 387-402.

Friedlmeier, W., Schäfermeier, E., Vasconcellos, V., \& Trommsdorff, G. (2008). Self-construal and cultural orientation as predictors for developmental goals: A comparison between Brazilian and German caregivers. European Journal of Developmental Psychology, 5, 39-67.

Gomide, P. I. C. (2000). A influência de filmes violentos e comportamento agressivo de crianças e adolescentes. Psicologia, Reflexão e Crítica, 13 (1), 127-142.

Harkeness, S. \& Super, C. M. (1986). The developmental Nicho: a conceptualization at the interface of child and culture. Internacional Journal of Development, 9, 545-569.

Harkness, S.; Super, C; Bermúdez, M. R. ; Moscardino, U; Rha, J; Mavridis, C. J. ; Bonichini, S; Huitrón, B; Welles-Nyström, B; Palacios, J; Hyun, O; Soriano, G; Zylicz, P. O. (2009). Parental Ethnotheories of children's learning. 
Harkness, S.; Super, C. (1994).The developmental niche: A theoretical framework for analyzing the household production of health, 38 (2), 217-226.

Hetherington, E. M. (1989). Coping with family transitions: Winners, losers, and survivors. Child Development, 60 (1), 1-14.

IBGE. (2010). Censo demográfico. Recuperado em 21 de maio, 2018. Disponível em: www.censo2010.ibge.gov.br.

Dados acessado dia 16/05/2020 às 23:16h. https://educa.ibge.gov.br/criancas/brasil/2697ie-ibge-educa/jovens/materias-especiais/20453-estatisticas-de-genero-indicadoressociais-das-mulheres-no-brasil.html.

Keller, H. (2011) Autonomy and Relatedness Revisited: Cultural Manifestations of Universal Human Needs. Child Development Perspectives, University of Osnabrueck, $0(0), 1-7$.

Lansford, J. E.; Criss, M. M.; Laird, R. D.; Shaw, D. S.; Pettit, G. S.; Bates, J. E. , Dodge, K. A. (2011). Reciprocal relations between parents'physical discipline and children's externalizing behavior during middle childhood and adolescence. Developmental and Psychopathology, 23, 225-238.

anz, P. M.; Bohorodzaner, S. ; Kampfner, E. (2010). Violencia y videojuegos en adolescentes chilenos y mexicanos. Revista Chilena de Neuropsicologia, 5 (3), 199- 206.

eme, V. B. R., \& Marturano, E. M. (2014). Preditores de comportamentos e competência acadêmica de crianças de famílias nucleares, monoparentais e recasadas. Psicologia: Reflexão e Crítica, 27(1), 153-162.

isboa, C. ; Koller, S. H. (2004). O microssistema Escolar e os Processos Proximais: Exemplos de Investigações Científicas e Intervenções Práticas. In: Koller, Sílvia Helena (Org.). Ecologia do desenvolvimento humano. Pesquisa e intervenção no Brasil. São Paulo: Casa do Psicólogo.

Macarini, S. M. et al. (2010). Práticas parentais uma revisão da literatura brasileira. Arquivos Brasileiros de Psicologia, 62 (1), 119-134. Rio de Janeiro

Maistro, M. A. (1997). As relações creche-famílias: um estudo de caso. Dissertação de Mestrado, Universidade Federal de Santa Catarina, Florianópolis.

Manfroi, E. C., Faraco, A. M. X., \& Vieira, M. L. (2010). Ambientes de Socialização das Crianças: impactos dos pais e do grupo de pares. In J. Segata, N. Machado, E. C. Manfroi, E.R. Goetz (Orgs.), Psicologia: inovações (pp. 113-122). Rio do Sul: Editora Unidavi. 
Maranhão, D. G.; Sarti, C.A. (2008). Creche e família: uma parceria necessária. Caderno de Pesquisa, São Paulo, n.133.

Martins, G. D. F.; Macarini, S. M.; Vieira, M. L.; Seidl de Moura, M. L.; Bussab, V. S. R.; Cruz, R. M.(2010). Escala de Crenças Parentais e Práticas de Cuidado (E-CPPC) na primeira infância.

Marin, A. H., Piccinini, C. A., Gonçalves, T. R., \& Tudge, J. R. H.. (2012). Práticas educativas parentais, problemas de comportamento e competência social de crianças em idade pré-escolar. Estudos de Psicologia (Natal), 17(1), 05-13.

Melchiori, L. E. ; Alvez, Z. M. M. B. ; Souza, D. C. ; Bugliani, M. A. P. (2007). Família e Creche: Crenças a Respeito de temperamento e desempenho de bebês. Psicologia: Teoria e Pesquisa, 23(3), 245-252.

Narvaz, M. G. ; Koller, S. H. (2004). O modelo Bioecológico do Desenvolvimento Humano. Em: Koller, Sílvia Helena (Org.). Ecologia do desenvolvimento humano. Pesquisa e intervenção no Brasil. São Paulo: Casa do Psicólogo.

unes, M. F. R.; Corsino, P. \& Didonet, V. (2011). Educação Infantil no Brasil: primeira etapa da educação básica. Brasília: UNESCO, Ministério da Educação.

liveira, Z. R. A. A parceria com a família na educação da criança. (2002). In:. Educação infantil: fundamentos e métodos. São Paulo: Cortez.

liveira, D.B.B. de (2011). Famílias contemporâneas: as voltas que o mundo dá e o reconhecimento jurídico da homoparentalidade. Curitiba: Juruá.

liveira, Z. M., Mello, A. M., Vitória, T., \& Rossetti-Ferreira, M. C. (2009). Creches: Crianças, faz de conta e cia (13a ed.). Rio de Janeiro: Vozes.

aniagua, P.; Palacios, J. (2007). Educação Infantil - resposta educativa à diversidade. Porto Alegre: Artmed.

Patterson, G. R.; Yoerger, K. (2002). A developmental model for early and late-onset delinquency.

In: J.B., Reid; G. R. Petterson; J. Snyder (eds.), Antisocial behavior in children and adolescents: A developmental analysis and model for intervention. Washington, DC, American Psychological Association, 147- 172.

Perez- Olmos, I. ; Pinzon, A. M.; González- Reyes, R.; Sanchez- Molano, J. (2005). Influencia de la televisión violenta em niños de uma escuela pública de Bogotá, Colombia. Revista de Salud Pública, 7 (1), 70-88.

Polleto, M., \& Koller, S. H. (2008). Contextos ecológicos: promotores de resiliência, fatores de risco e de proteção. Estudos de Psicologia, 25 (3), 405-416. 
Sarti, C. A. (2011). A família como espelho: um estudo sobre a moral dos pobres. ( $7^{\mathrm{a}}$ ed.). São Paulo: Cortez.

Silveira, L. M. O. B., \& Wagner, A. (2012). A interação família-escola diante dos problemas de comportamento da criança: estudos de caso. Psicologia da Educação, (35), 95-119.

Souza, C. D.; Vieira, M. L. \& Crepaldi, M. A. (2015). O que dizem professores da préescola sobre agressividade entre crianças, 46 (1), 46-56.

Spodek, B. ; Saracho, O. N. Ensinando crianças de 3 a 8 anos. Porto Alegre: ArtMed, 1998.

Tremblay, R. E. (2000). The Development of aggressive behavior during childhood: What have we learned in the past century? International Journal of Behavioral Development, 24, 129-141.

Trindade, T. O (2017). Crenças de Professores e Pais sobre o desenvolvimento da Criança durante a Educação Infantil, Dissertação de Mestrado , UERJ . Dissertação não publicada.

asconcellos, V. M. R., Seabra, K. C. ,Eisenberg, Z. , Moreira, A. R. P. (2012). O lugar da creche nos debates sobre parentalidade e coparentalidade. In: Piccinini, César Augusto, Alvarenga, Patrícia. Maternidade e Paternidade: a parentalidade em diferentes contextos. São Paulo: Casa do Psicólogo.

igotsky, L. S. (2007). A formação da mente humana: o desenvolvimento dos processos psicológicos superiors. São Paulo: Martins Fontes.

leber, L. N. D. (2008). Família e desenvolvimento: Visões Interdisciplinares. Curitiba: Juruá.

Zanetti, S. A. S., \& Gomes, I. C. (2014). Relação entre funções parentais e o comportamento de crianças pré-escolares. Boletim de Psicologia, 64(140), 1-20. 


\section{ANEXO I}

\section{INSTRUMENTOS PAIS}

- Dados de Identificação

- Dados Sociodemográficos

- Termo de Consentimento Livre e Esclarecido

- Inventário do Clima Familiar (ICF)

- Escala de Crenças Parentais e Práticas de Cuidado (E-CPPC) na primeira Infância. 
PROJETO DE PESQUISA: PRÁTICAS EDUCATIVAS PARENTAIS E O COMPORTAMENTO DAS CRIANÇAS NO CONTEXTO DA EDUCAÇÃO INFANTIL

\section{$\underline{\text { Dados de Identificação }}$}

Código

Nome

da

mãe/pai:

Endereço:

Telefones:

e-mail:

Instituição

onde

o

filho

(a)

estuda:

Data: 
PROJETO DE PESQUISA: PRÁTICAS EDUCATIVAS PARENTAIS E O COMPORTAMENTO DAS CRIANÇAS NO CONTEXTO DA EDUCAÇÃO INFANTIL

Dados Sociodemográficos- Pais

Código

Idade:

Escolaridade:

Profissão:

Mora com a criança: ( ) SIM ( ) NÃO

Com quem fica seu filho(a) quando não está na escola:

Data:

Estado civil:

Com quem fica seu filho(a) quando não está na escola:

ปิ 


\section{Pontifícia Universidade Catálica DO RIO DE JANEIRO \\ Programa de Pós-graduação em Psicologia Clínica \\ Departamento de Psicologia}

Termo de Consentimento Livre e Esclarecido

Pesquisa: Práticas Educativas Parentais e o Comportamento das crianças no contexto da Educação Infantil.

Pesquisadora: Thaís de Oliveira Trindade

\section{1- Natureza da pesquisa}

Você está sendo convidada a participar desta pesquisa, que tem como objetivo investigar as relações das práticas educativas parentais e as características familiares nos comportamentos das crianças de pré-escolares no contexto escolar público do Rio de Janeiro.

\section{2- Participantes da pesquisa}

Participarão deste estudo 50 pais ou mães de crianças com idades entre 3 e 5 anos, em idades variadas, e os respectivos professores das crianças de escolas públicas do Município do Rio de Janeiro.

\section{3- Envolvimento na pesquisa}

A participação será voluntária. Caso você aceite em participar, solicitamos a permissão para que possamos apresentar os instrumentos de pesquisa pessoalmente e pedir o seu preenchimento. Você tem a liberdade de recusar a participação em qualquer etapa deste estudo sem qualquer prejuízo para você. A qualquer momento você poderá pedir mais informações sobre a pesquisa com a responsável, Profa. Thaís de Oliveira Trindade, através dos telefones (21) 2502-4574 na Pontifícia Universidade Católica do Rio de Janeiro (PUC-RIO) R. Marquês de São Vicente, 225 - Gávea, Rio de Janeiro - RJ, 22451-000. Prédio Cardeal Leme, $2^{\circ}$ andar, Departamento de Psicologia.

\section{4- Confidencialidade}

Todas as informações coletadas neste estudo são estritamente confidenciais e serão utilizadas apenas para a pesquisa. Os instrumentos serão identificados por códigos e apresentado sem qualquer identificação. Os dados da pesquisa poderão ser publicados.

\section{5- Benefícios}

Ao participar desta pesquisa você terá o benefício de pensar sua prática como pai ou mãe, sua relação com seu filho(a) e a instituição de ensino em que ele estuda. Espera-se, que os resultados dessa pesquisa possam ser usadas em programas de educação, buscando ampliar a divulgação sobre a relação dos educadores e da família com a escola e suas consequências para o desenvolvimento das crianças. Desta forma, as instituições participantes terão o benefício de pensar estratégias que abordem esse tema e a melhor relação possível entre pais e educadores para o desenvolvimento das crianças presentes nas instituições.

\section{6- Riscos:}

Nesta pesquisa você corre o risco de ficar cansado durante o preenchimento dos instrumentos, todavia eles poderão ser minimizados por você ter o tempo que 
achar necessário para fazê-lo. Sendo o único risco que você possa ter ao participar dessa pesquisa.

7- Pagamento

Você não terá nenhum tipo de despesa por participar desta pesquisa, e nada será pago por sua participação. Entretanto, ao final da pesquisa você receberá um documento contendo seus principais resultados e discussão.

Tendo em vista os itens acima apresentados, eu,__de forma livre e esclarecida, manifesto meu interesse em participar da pesquisa.

Rio de Janeiro,

Assinatura participante

Thaís de Oliveira Trindade

Pesquisadora

Caso você tenha dificuldade de entrar em contato com o pesquisador responsável, comunique o fato à Comissão de Ética e Pesquisa da PUC-Rio: R. Marquês de São Vicente, 225 - Gávea, Rio de Janeiro - RJ, 22451-000. 
Inventário do Clima Familiar (ICF)

Nome:

Sexo:

Idade:

Escolaridade:

Data:

Este questionário trata de um tema sobre o qual todos nós temos muito a dizer: a nossa família. Gostaríamos de pedir que você pense sobre o(s) membro(s) de sua família e sobre como eles, geralmente, se relacionam.

Abaixo estão algumas frases que descrevem situações e sentimentos que podem ou não ocorrer no dia-a-dia de qualquer família. Leia cada frase e responda se ela se aplica ou não à sua família, utilizando os seguintes números:

\begin{tabular}{|c|c|c|c|c|}
\hline $\begin{array}{c}\text { Não concordo } \\
\text { de jeito nenhum }\end{array}$ & $\begin{array}{c}\text { Concordo um } \\
\text { pouco }\end{array}$ & $\begin{array}{c}\text { Concordo mais } \\
\text { ou menos }\end{array}$ & $\begin{array}{c}\text { Concordo } \\
\text { muito }\end{array}$ & $\begin{array}{c}\text { Concordo com- } \\
\text { pletamente }\end{array}$ \\
\hline $\mathbf{1}$ & $\mathbf{2}$ & $\mathbf{3}$ & $\mathbf{4}$ & $\mathbf{5}$ \\
\hline
\end{tabular}




\begin{tabular}{|c|c|c|c|c|}
\hline & De jeito & Pouco & Mais ou & Muito \\
\hline Em minha família... & nenhum & & menos & \\
\hline
\end{tabular}

1. Procuramos ajudar as pessoas da

1

2

3

5 nossa família quando percebemos que estão com problemas.

\begin{tabular}{|llllll}
\hline 2. As proibições são constantes. & 1 & 2 & 3 & 4 & 5 \\
\hline 3. Uns mandam e outros obedecem. & 1 & 2 & 3 & 4 & 5
\end{tabular}

4. As pessoas zombam umas das outras.

1

2

3

4

5

5. Briga-se por qualquer coisa. 1

23

34

6. Algumas pessoas deixam de fazer as 1

2

3

5 suas coisas para auxiliar as outras pessoas da família.

7. Não importa a vontade da maioria, a 1

12

3

4

5 decisão final é sempre da mesma pessoa.

8. As pessoas irritam umas às outras.

1

2

3

4

5

9. As pessoas gostam de passear e de 1

2

3

4 fazer coisas juntas.

10. As pessoas resolvem os problemas 1 2 3 4 5 brigando. 


\begin{tabular}{|c|c|c|c|c|c|}
\hline $\begin{array}{l}\text { 11. As pessoas criticam umas às outras } \\
\text { frequentemente. }\end{array}$ & 1 & 2 & 3 & 4 & 5 \\
\hline $\begin{array}{l}\text { 12. Resolver problemas significa discus- } \\
\text { são e brigas. }\end{array}$ & 1 & 2 & 3 & 4 & 5 \\
\hline $\begin{array}{l}\text { 13. As pessoas tentam ajudar umas às } \\
\text { outras quando as coisas não vão bem. }\end{array}$ & 1 & 2 & 3 & 4 & 5 \\
\hline 14. As pessoas gostam umas das outras. & 1 & 2 & 3 & 4 & 5 \\
\hline $\begin{array}{l}\text { 15. Sinto que existe união entre os mem- } \\
\text { bros. }\end{array}$ & 1 & 2 & 3 & 4 & 5 \\
\hline 16. Os mais velhos mandam mais. & 1 & 2 & 3 & 4 & 5 \\
\hline $\begin{array}{l}\text { 17. As pessoas se sentem próximas umas } \\
\text { das outras. }\end{array}$ & 1 & 2 & 3 & 4 & 5 \\
\hline $\begin{array}{l}\text { 18. O(s) filho(s) tem pouco poder nas de- } \\
\text { cisões familiares. }\end{array}$ & 1 & 2 & 3 & 4 & 5 \\
\hline $\begin{array}{l}\text { 19. Temos prazer e alegria em passar o } \\
\text { tempo juntos. }\end{array}$ & 1 & 2 & 3 & 4 & 5 \\
\hline $\begin{array}{l}\text { 20. Algumas pessoas resolvem os pro- } \\
\text { blemas de maneira autoritária. }\end{array}$ & 1 & 2 & 3 & 4 & 5 \\
\hline $\begin{array}{l}\text { 21. Ajudamos financeiramente uns aos } \\
\text { outros. }\end{array}$ & 1 & 2 & 3 & 4 & 5 \\
\hline $\begin{array}{l}\text { 22. As pessoas me ajudam a fazer as coi- } \\
\text { sas quando não tenho tempo. }\end{array}$ & 1 & 2 & 3 & 4 & 5 \\
\hline
\end{tabular}


Lembre-se de que não existem respostas certas ou erradas. Nós só desejamos saber como as coisas têm estado em sua família ultimamente. 
Escala de Crenças Parentais e Práticas de Cuidado (E-CPPC) na primeira infância

Gabriela Dal Forno Martins; Samira Mafioletti Macarini; Mauro Luís Vieira. Maria Lucia Seidl de Moura; Vera Silvia Raad Bussab; Roberto Moraes Cruz.

Para a entrevistadora: Para cada item, pergunte o quanto a mãe realizou essas atividades. Leia a afirmação, mostre no questionário que está diante da entrevistada, leia as opções e peça que indique sua resposta.

a) O quanto você realizou cada uma dessas atividades com a criança? De 1=nunca, até $5=$ sempre.

\begin{tabular}{|c|c|c|c|c|c|}
\hline & $\begin{array}{c}\text { Nunca } \\
1\end{array}$ & $\begin{array}{c}\text { Raramente } \\
2\end{array}$ & $\begin{array}{c}\text { Às vezes } \\
3\end{array}$ & $\begin{array}{l}\text { Quase sem- } \\
\text { pre } \\
4\end{array}$ & $\begin{array}{c}\text { Sempre } \\
5\end{array}$ \\
\hline 1. Socorrer quando está chorando. & & & & & \\
\hline 2. Alimentar. & & & & & \\
\hline 3. Manter limpa. & & & & & \\
\hline 4. Cuidar para que durma e descanse. & & & & & \\
\hline 5. Não deixar que passe frio ou calor. & & & & & \\
\hline 6. Carregar no colo. & & & & & \\
\hline 7. Ter sempre por perto. & & & & & \\
\hline 8. Abraçar e beijar. & & & & & \\
\hline 9. Dormir junto na rede ou cama. & & & & & \\
\hline $\begin{array}{l}\text { 10. Tentar evitar que se acidente (cuidados de } \\
\text { segurança). }\end{array}$ & & & & & \\
\hline 11. Fazer cócegas. & & & & & \\
\hline 12. Fazer massagem. & & & & & \\
\hline 13. Deixar livre para correr, nadar, trepar. & & & & & \\
\hline $\begin{array}{l}\text { 14. Brincadeiras de luta, de se embolar (corpo- } \\
\text { rais) }\end{array}$ & & & & & \\
\hline 15. Fazer atividades físicas. & & & & & \\
\hline
\end{tabular}




\begin{tabular}{|l|l|l|l|l|l|}
\hline 16. Dar brinquedos. & & & & & \\
\hline 17. Jogar jogos. & & & & & \\
\hline 18. Pendurar brinquedos no berço. & & & & & \\
\hline 19. Ver livrinhos juntos. & & & & & \\
\hline 20. Mostrar coisas interessantes. & & & & & \\
\hline 21. Conversar. & & & & & \\
\hline 22. Explicar coisas. & & & & & \\
\hline 23. Ouvir o que tem a dizer. & & & & & \\
\hline 24. Responder a perguntas. & & & & & \\
\hline 25. Ficar frente a frente, olho no olho. & & & & & \\
\hline
\end{tabular}


ANEXO II

\section{INSTRUMENTOS PROFESSORES}

- Dados de Identificação

- Dados Sociodemográficos

- Termo de Consentimento Livre e Esclarecido

- Entrevista dirigida 
PROJETO DE PESQUISA: PRÁTICAS EDUCATIVAS PARENTAIS E O COMPORTAMENTO DAS CRIANÇAS NO CONTEXTO DA EDUCAÇÃO INFANTIL

\section{$\underline{\text { Dados de Identificação }}$}

Código

Nome:

Endereço:

Telefones:

E-mail:

Instituição onde trabalha:

Data:

ปิ 
PROJETO DE PESQUISA: PRÁTICAS EDUCATIVAS PARENTAIS E O COMPORTAMENTO DAS CRIANÇAS NO CONTEXTO DA EDUCAÇÃO INFANTIL

\section{$\underline{\text { Dados Sociodemográficos- Professores }}$}

Código

Idade: Estado civil:

Escolaridade:

Data: 


\section{Pontifícia Universidade Católica DO RIO DE JANEIRO \\ Programa de Pós-graduação em Psicologia Clínica \\ Departamento de Psicologia}

Termo de Consentimento Livre e Esclarecido

Pesquisa: Práticas Educativas Parentais e o Comportamento das crianças no contexto da Educação Infantil.

Pesquisadora: Thaís de Oliveira Trindade

1- Natureza da pesquisa

Você está sendo convidada a participar desta pesquisa, que tem como objetivo investigar as relações das práticas educativas parentais e as características familiares nos comportamentos das crianças de pré-escolares no contexto escolar público do Rio de Janeiro.

\section{2- Participantes da pesquisa}

Participarão deste estudo 50 pais ou mães de crianças com idades entre 3 e 5 anos, em idades variadas, e os respectivos professores das crianças de escolas públicas do Município do Rio de Janeiro.

\section{3- Envolvimento na pesquisa}

A participação será voluntária. Caso você aceite em participar, solicitamos a permissão para que possamos apresentar os instrumentos de pesquisa pessoalmente e pedir o seu preenchimento. Você tem a liberdade de recusar a participação em qualquer etapa deste estudo sem qualquer prejuízo para você. A qualquer momento você poderá pedir mais informações sobre a pesquisa com a responsável, Profa. Thaís de Oliveira Trindade, através dos telefones (21) 2502-4574 na Pontifícia Universidade Católica do Rio de Janeiro (PUC-RIO) R. Marquês de São Vicente, 225 - Gávea, Rio de Janeiro - RJ, 22451-000. Prédio Cardeal Leme, $2^{\circ}$ andar, Departamento de Psicologia.

\section{4- Confidencialidade}

Todas as informações coletadas neste estudo são estritamente confidenciais e serão utilizadas apenas para a pesquisa. Os instrumentos serão identificados por códigos e apresentado sem qualquer identificação. Os dados da pesquisa poderão ser publicados.

\section{5- Benefícios}

Ao participar desta pesquisa você terá o benefício de pensar sua prática como pai ou mãe, sua relação com seu filho(a) e a instituição de ensino em que ele estuda. Espera-se, que os resultados dessa pesquisa possam ser usadas em programas de educação, buscando ampliar a divulgação sobre a relação dos educadores e da família com a escola e suas consequências para o desenvolvimento das crianças. Desta forma, as instituições participantes terão o benefício de pensar estratégias que abordem esse tema e a melhor relação possível entre pais e educadores para o desenvolvimento das crianças presentes nas instituições.

\section{6- Riscos:}

Nesta pesquisa você corre o risco de ficar cansado durante o preenchimento dos instrumentos, todavia eles poderão ser minimizados por você ter o tempo que achar necessário para fazê-lo. Sendo o único risco que você possa ter ao participar dessa pesquisa. 


\section{7- Pagamento}

Você não terá nenhum tipo de despesa por participar desta pesquisa, e nada será pago por sua participação. Entretanto, ao final da pesquisa você receberá um documento contendo seus principais resultados e discussão.

Tendo em vista os itens acima apresentados, eu,__, de forma livre e esclarecida, manifesto meu interesse em participar da pesquisa.

Rio de Janeiro,

Assinatura participante

Thaís de Oliveira Trindade

Pesquisadora

Caso você tenha dificuldade de entrar em contato com o pesquisador responsável, comunique o fato à Comissão de Ética e Pesquisa da PUC-Rio: R. Marquês de São Vicente, 225 - Gávea, Rio de Janeiro - RJ, 22451-000. 
Entrevista dirigida para professores:

1. Descreva o comportamento dessa criança nos momentos de socialização com seus pares.

2. Há necessidade de mediar conflitos dessa criança com outras frequentemente?

3. Essa criança consegue respeitar as regras gerais da turma com facilidade?

4. Você conseguiria descrever, a partir das observações no dia a dia dessa criança, como é, em situações de brincadeiras em que algumas regras são estabelecidas previamente, o comportamento dessa criança, especificamente nesses momentos interativos?

5. Se você pudesse descrever o comportamento dessa criança, no seu dia a dia na escola, em cinco palavras, quais palavras você utilizaria? 